\title{
Sediment Quality and Comparison to Historical Water Ouality, Little Arkansas River Basin, South-Central
} Kansas, 2007

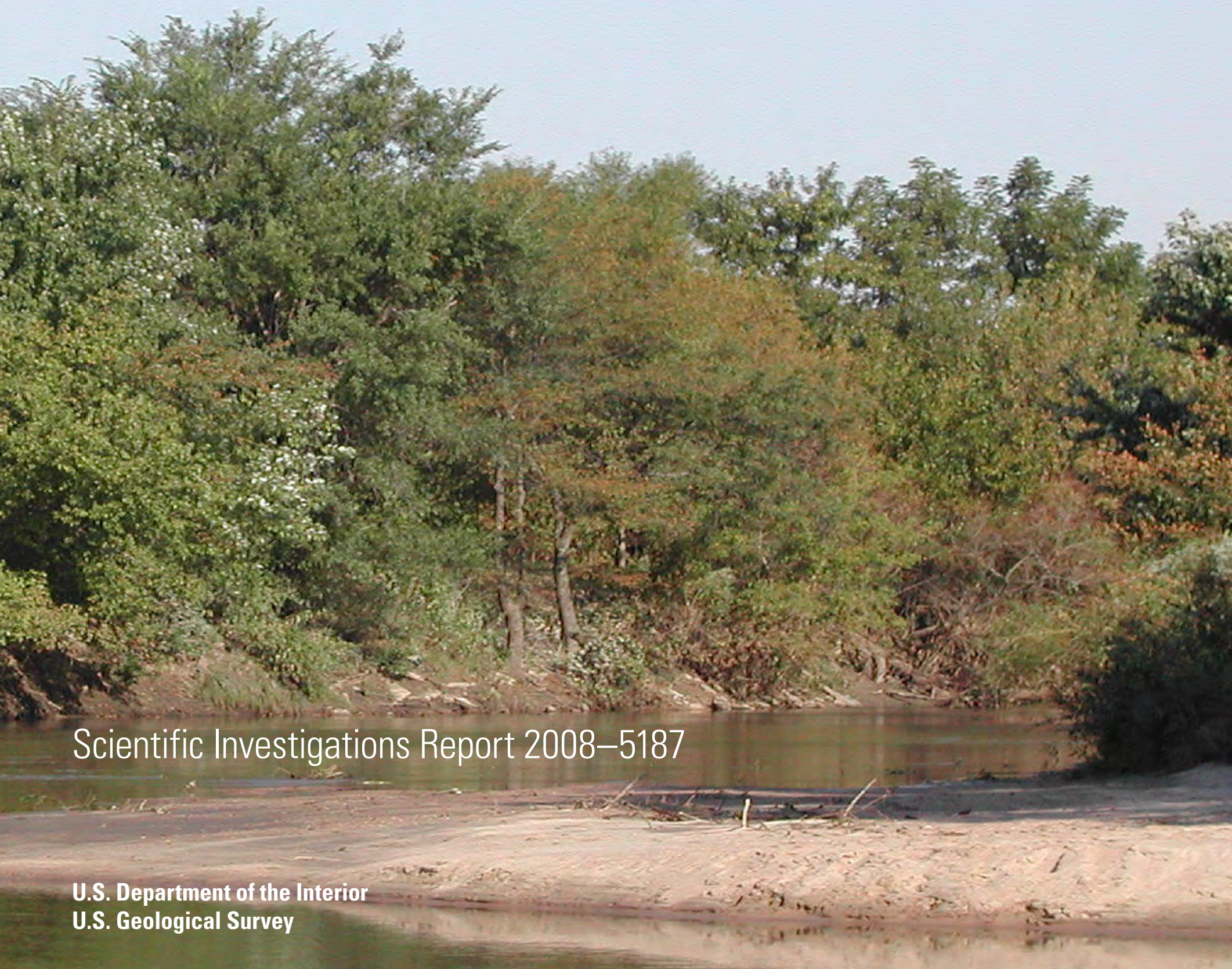


Cover photographs. Little Arkansas River near Valley Center, Kansas (photograph taken by Eric Looper, USGS). Inset on back cover: USGS hydrologist collecting a streambed sediment sample from the Little Arkansas River at Wichita, Kansas (photograph taken by Patrick Rasmussen, USGS). 


\section{Sediment Quality and Comparison to Historical Water Quality, Little Arkansas River Basin, South-Central Kansas, 2007}

By Kyle E. Juracek and Patrick P. Rasmussen

Prepared in cooperation with the

Kansas Department of Health and Environment

Scientific Investigations Report 2008-5187 


\section{U.S. Department of the Interior DIRK KEMPTHORNE, Secretary}

\section{U.S. Geological Survey \\ Mark D. Myers, Director}

\section{U.S. Geological Survey, Reston, Virginia: 2008}

For product and ordering information:

World Wide Web: http://www.usgs.gov/pubprod

Telephone: 1-888-ASK-USGS

For more information on the USGS — the Federal source for science about the Earth, its natural and living resources, natural hazards, and the environment:

World Wide Web: http://www.usgs.gov

Telephone: 1-888-ASK-USGS

Any use of trade, product, or firm names is for descriptive purposes only and does not imply endorsement by the U.S. Government.

Although this report is in the public domain, permission must be secured from the individual copyright owners to reproduce any copyrighted materials contained within this report.

Suggested citation:

Juracek, K.E., and Rasmussen, P.P., 2008, Sediment quality and comparison to historical water quality, Little Arkansas River Basin, south-central Kansas, 2007: U.S. Geological Survey Scientific Investigations Report 2008-5187, 47 p. 


\section{Contents}

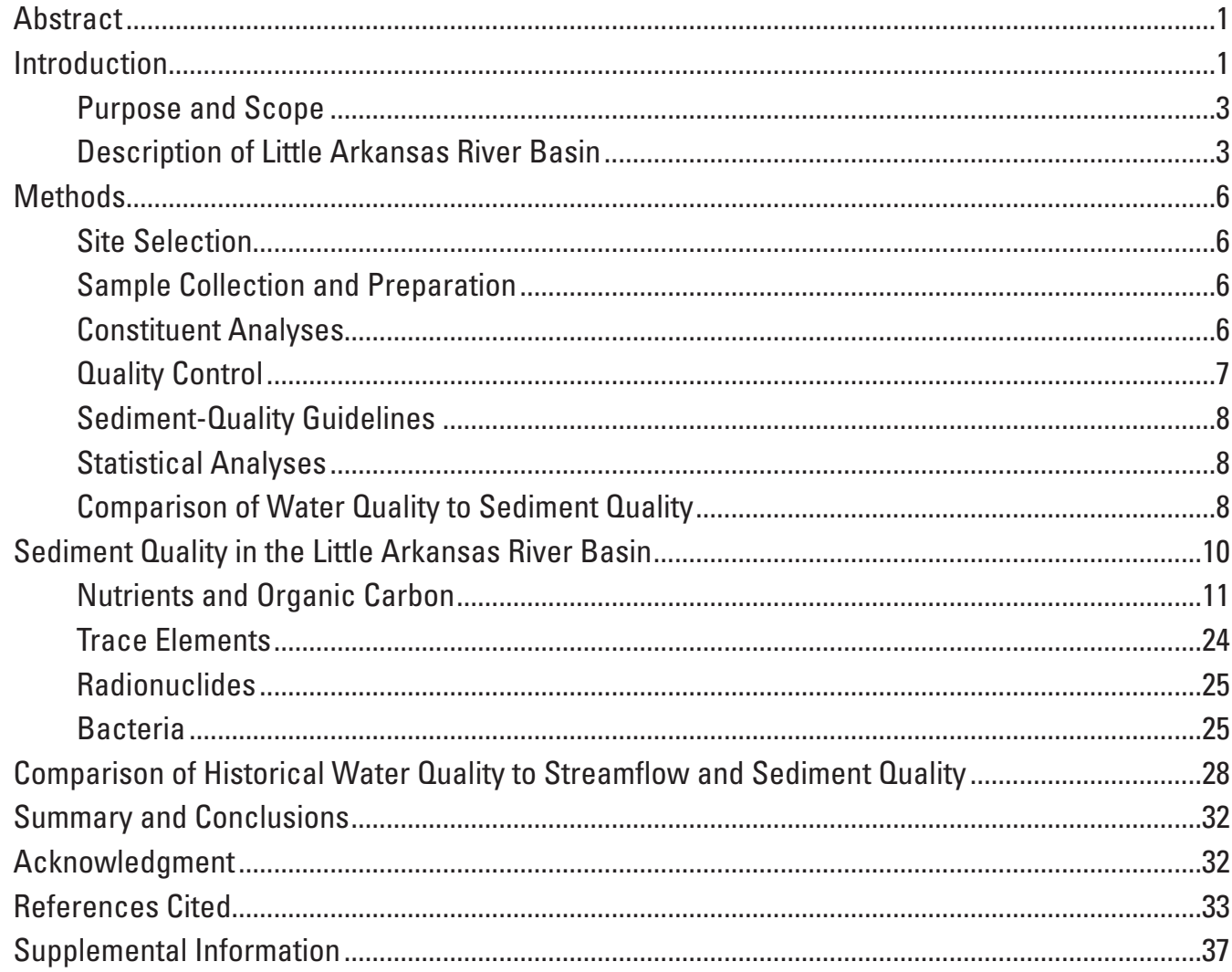

\section{Figures}

1-2. Maps showing:

1. Physiography of Kansas and location of the Little Arkansas River Basin

.2

2. Land use in the Little Arkansas River Basin (1988-90) and location of streambed-sediment sampling sites.

3. Graph showing mean daily streamflow from October 1, 2006 to September 30, 2007 for (A) Little Arkansas River at Alta Mills, Kansas, and (B) Little Arkansas River at Valley Center, Kansas.

4-6. Maps showing:

4. Original, clay-normalized, and organic-carbon-normalized concentrations of particulate nitrogen and phosphorus in streambed-sediment samples collected in the Little Arkansas River Basin, south-central Kansas, January and March 2007.

5. Concentrated animal feeding operations (CAFOs) in the Little Arkansas River Basin, south-central Kansas, June 2007.

6. Original $(A)$ and clay-normalized $(B)$ concentrations of particulate organic carbon in streambed-sediment samples collected in the Little Arkansas River Basin, south-central Kansas, January and March 2007. 


\section{7-9. Graphs showing:}

7. Variation in particulate nitrogen $(A)$ and phosphorus $(B)$ concentrations in relation to particulate organic carbon concentrations for streambed-sediment samples collected in the Little Arkansas River Basin, south-central Kansas, January, March, and August 2007......

8. Variation in particulate nitrogen $(A)$ and phosphorus $(B)$ concentrations for streambedsediment samples collected in the Little Arkansas River Basin, south-central Kansas, January, March, and August 2007.

9. Variation in copper $(A)$ and zinc $(B)$ concentrations in relation to particulate organic carbon concentrations for streambed-sediment samples collected in the Little Arkansas River Basin, south-central Kansas, January, March, and August 2007.

10. Maps showing original $(A)$ and clay-normalized $(B)$ cesium-137 activity in streambedsediment samples collected in the Little Arkansas River Basin, south-central Kansas, January and March 2007.

11-14. Graphs showing:

11. Variation in beryllium-7 $(A)$, cesium-137 $(B)$, and lead-210 $(C)$ activities in relation to particulate organic carbon concentrations for streambed-sediment samples collected in the Little Arkansas River Basin, south-central Kansas, January, March, and August 2007

12. Variation in particulate nitrogen for water-quality samples (normalized by total suspended solids concentration) and particulate nitrogen for streambed-sediment samples (normalized by percentage of clay) in relation to discharge for eight selected sites in the Little Arkansas River Basin, south-central Kansas.

13. Variation in particulate phosphorus for water-quality samples (normalized by total suspended solids concentration) and particulate phosphorus for streambed-sediment samples (normalized by percentage of clay) in relation to discharge for eight selected sites in the Little Arkansas River Basin, south-central Kansas.

14. Variation in particulate organic carbon for water-quality samples (normalized by total suspended solids concentration) and particulate organic carbon for streambedsediment samples (normalized by percentage of clay) in relation to discharge for eight selected sites in the Little Arkansas River Basin, south-central Kansas.

\section{Tables}

1. Analyses performed on streambed-sediment samples from the Little Arkansas River Basin, south-central Kansas.

2. Relative percentage differences for constituent concentrations or activities and bacteria densities in split-replicate and sequential-replicate streambed-sediment samples from the Little Arkansas River Basin, south-central Kansas..

3. Sediment-quality guidelines for selected trace elements and associated bioaccumulation index.

4. Water-quality sampling sites included in this study......

5. Concentration and activity ranges for selected constituents in streambed-sediment samples collected in the Little Arkansas River Basin, south-central Kansas, January and March 2007

6. Results of correlation analyses for original and clay-normalized particulate nitrogen and phosphorus concentrations for streambed-sediment sampling sites as compared to land use in the sampling-site subbasins. 
7. Densities of total coliform, Escherichia coli, fecal coliform, and enterococci for streambed-sediment samples collected from the Little Arkansas River Basin, southcentral Kansas, September 2007.

A1. Dates sampled and latitude and longitude coordinates for streambed-sediment sampling sites in the Little Arkansas River Basin, south-central Kansas

A2. Percentage of silt and clay and constituent concentrations or activities for streambed-sediment samples collected from the Little Arkansas River Basin, south-central Kansas, January and March 2007.

A3. Percentage of silt and clay and constituent concentrations or activities for streambed-sediment samples collected from the Little Arkansas River Basin, south-central Kansas, August 2007

\section{Conversion Factors, Abbreviations, and Datum}

\begin{tabular}{|c|c|c|}
\hline Multiply & By & To obtain \\
\hline \multicolumn{3}{|c|}{ Length } \\
\hline inch (in.) & 2.54 & centimeter $(\mathrm{cm})$ \\
\hline foot $(\mathrm{ft})$ & 0.3048 & meter $(\mathrm{m})$ \\
\hline micron $(\mu \mathrm{m})$ & $3.937 \times 10^{-5}$ & inch (in.) \\
\hline mile (mi) & 1.609 & kilometer $(\mathrm{km})$ \\
\hline \multicolumn{3}{|c|}{ Area } \\
\hline acre & 4,047 & square meter $\left(\mathrm{m}^{2}\right)$ \\
\hline acre & 0.4047 & hectare (ha) \\
\hline acre & 0.004047 & square kilometer $\left(\mathrm{km}^{2}\right)$ \\
\hline square foot $\left(\mathrm{ft}^{2}\right)$ & 0.09290 & square meter $\left(\mathrm{m}^{2}\right)$ \\
\hline square mile $\left(\mathrm{mi}^{2}\right)$ & 259.0 & hectare (ha) \\
\hline square mile $\left(\mathrm{mi}^{2}\right)$ & 2.590 & square kilometer $\left(\mathrm{km}^{2}\right)$ \\
\hline \multicolumn{3}{|c|}{ Volume } \\
\hline cubic foot $\left(\mathrm{ft}^{3}\right)$ & 0.02832 & cubic meter $\left(\mathrm{m}^{3}\right)$ \\
\hline acre-foot (acre-ft) & 1,233 & cubic meter $\left(\mathrm{m}^{3}\right)$ \\
\hline \multicolumn{3}{|c|}{ Flow rate } \\
\hline cubic foot per second $\left(\mathrm{ft}^{3} / \mathrm{s}\right)$ & 0.02832 & cubic meter per second $\left(\mathrm{m}^{3} / \mathrm{s}\right)$ \\
\hline \multicolumn{3}{|c|}{ Mass } \\
\hline milligram per kilogram $(\mathrm{mg} / \mathrm{kg})$ & 1.0 & part per million (ppm) \\
\hline pound (lb) & 0.4536 & kilogram (kg) \\
\hline \multicolumn{3}{|c|}{ Density } \\
\hline pound per cubic foot $\left(\mathrm{lb} / \mathrm{ft}^{3}\right)$ & 16.02 & kilogram per cubic meter $\left(\mathrm{kg} / \mathrm{m}^{3}\right)$ \\
\hline
\end{tabular}

Temperature in degrees Celsius $\left({ }^{\circ} \mathrm{C}\right)$ may be converted to degrees Fahrenheit $\left({ }^{\circ} \mathrm{F}\right)$ as follows:

$$
{ }^{\circ} \mathrm{F}=\left(1.8 \times^{\circ} \mathrm{C}\right)+32
$$

Temperature in degrees Fahrenheit $\left({ }^{\circ} \mathrm{F}\right)$ may be converted to degrees Celsius $\left({ }^{\circ} \mathrm{C}\right)$ as follows:

$$
{ }^{\circ} \mathrm{C}=\left({ }^{\circ} \mathrm{F}-32\right) / 1.8
$$

Horizontal coordinate information is referenced to the North American Datum of 1983 (NAD 83). 



\title{
Sediment Quality and Comparison to Historical Water Quality, Little Arkansas River Basin, South-Central Kansas, 2007
}

\author{
By Kyle E. Juracek and Patrick P. Rasmussen
}

\section{Abstract}

The spatial and temporal variability in streambed-sediment quality and its relation to historical water quality was assessed to provide guidance for the development of total maximum daily loads and the implementation of best-management practices in the Little Arkansas River Basin, southcentral Kansas. Streambed-sediment samples were collected at 26 sites in 2007, sieved to isolate the less than 63-micron fraction (that is, the silt and clay), and analyzed for selected nutrients (total nitrogen and total phosphorus), organic and total carbon, 25 trace elements, and the radionuclides beryllium-7, cesium-137, lead-210, and radium-226. At eight sites, streambed-sediment samples also were collected and analyzed for bacteria.

Particulate nitrogen, phosphorus, and organic carbon concentrations in the streambed sediment varied substantially spatially and temporally, and positive correlations among the three constituents were statistically significant. Along the main-stem Little Arkansas River, streambed-sediment concentrations of particulate nitrogen and phosphorus generally were larger at and downstream from Alta Mills, Kansas. The largest particulate nitrogen concentrations were measured in samples collected in the Emma Creek subbasin and may be related to livestock and poultry production. The largest particulate phosphorus concentrations in the basin were measured in samples collected along the main-stem Little Arkansas River downstream from Alta Mills, Kansas. Particulate nitrogen, phosphorus, and organic carbon content in the water and streambedsediment samples typically decreased as streamflow increased. This inverse relation may be caused by an increased contribution of sediment from channel-bank sources during high flows and (or) increased particle sizes transported by the high flows.

Trace element concentrations in the streambed sediment varied from site to site and typically were less than thresholdeffects guidelines for possible adverse biological effects. The largest copper, lead, silver, and zinc concentrations, measured for a sample collected from Sand Creek downstream from Newton, Kansas, likely were related to urban sources of contamination.
Radionuclide activities and bacterial densities in the streambed sediment varied throughout the basin. Variability in the former may be indicative of subbasin differences in the contribution of sediment from surface-soil and channel-bank sources.

Streambed sediment may be useful for reconnaissance purposes to determine sources of particulate nitrogen, phosphorus, organic carbon, and other sediment-associated constituents in the basin. If flow conditions prior to streambed-sediment sampling and during water-quality sampling are considered, it may be possible to use streambed sediment as an indicator of water quality for nitrogen, phosphorus, and organic carbon. Flow conditions affect sediment-associated constituent concentrations in streambed-sediment and water samples, in part, because the sources of sediment (surface soils, channel banks) can vary with flow as can the size of the particles transported.

\section{Introduction}

Nationally, water bodies that are impaired with respect to water quality are listed under Section 303(d) of the Federal Clean Water Act of 1972. The 303(d) list is a priority list that identifies water bodies that do not meet water-quality standards that are based on the use of the water bodies. For each impaired water body on the 303(d) list, a State is required to develop a total maximum daily load (TMDL). A TMDL is an estimate of the maximum pollutant load (material transported during a specified time period) from point and nonpoint sources that a receiving water can accept without exceeding water-quality standards (U.S. Environmental Protection Agency, 1991). Whereas progress has been made in improving water quality through the reduction of point-source contributions to impairment (for example, reductions achieved through the National Pollutant Discharge Elimination System process), nonpoint sources have proven more difficult to address.

The Little Arkansas River Basin in south-central Kansas (fig. 1) is listed as a high priority TMDL basin. Within the basin, several stream segments are on the 303(d) list for one 


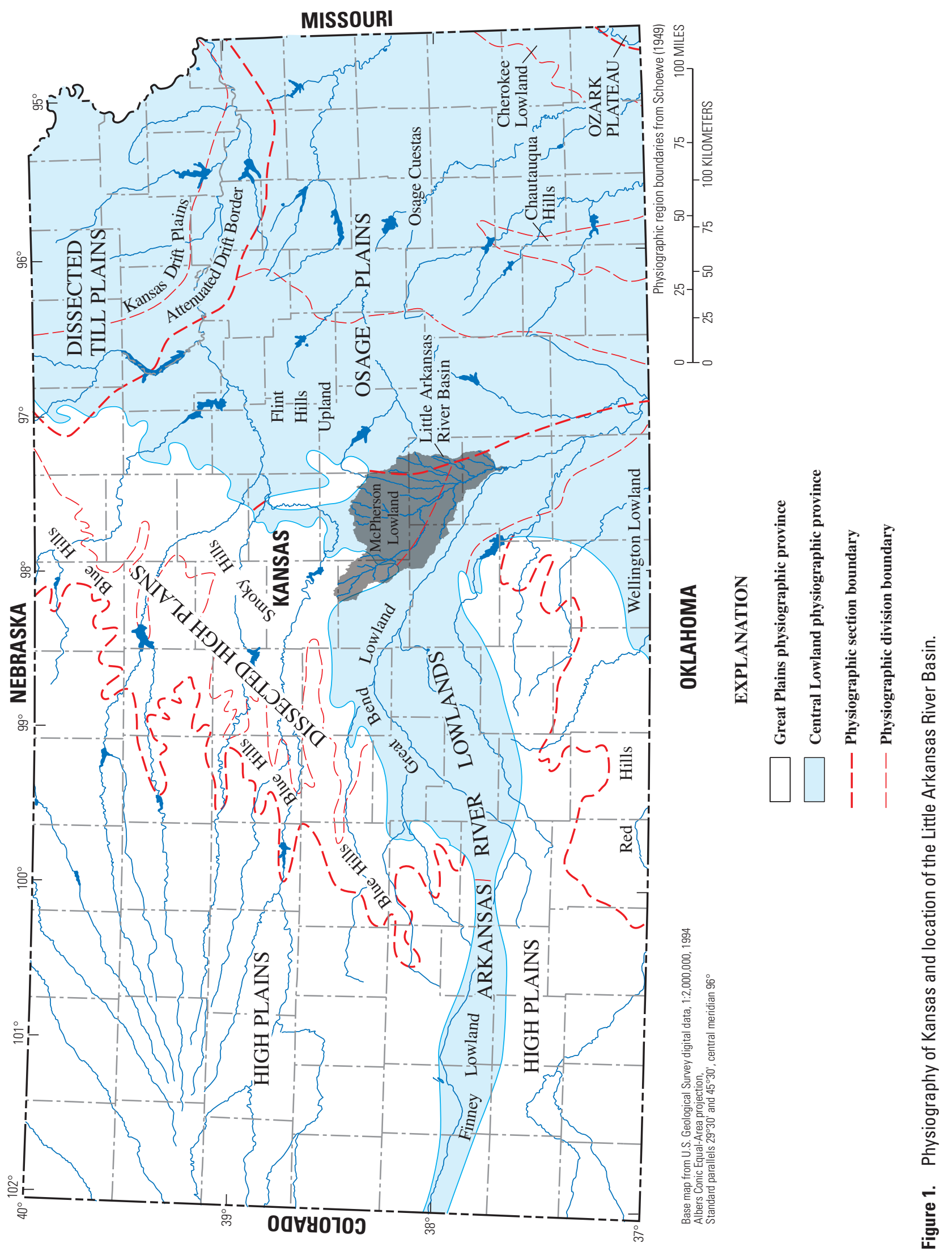


or more constituents including sediment, ammonia, fecal coliform bacteria, dissolved oxygen, and atrazine (Kansas Department of Health and Environment, 2007). Impaired streams in the basin include the Little Arkansas River, Sand Creek, and Turkey Creek (fig. 2). To achieve TMDL objectives for improving water quality, best-management practices (BMPs) may be implemented to reduce nonpoint-source contributions to impairment. Ideally, BMP implementation within the basin focuses on identified high priority subbasins to increase the likelihood of achieving water-quality improvements.

Sediment quality is an important environmental concern because many water-quality constituents preferentially sorb to, and are transported with, sediment in the fluvial environment. Sediment is an important determinant of water quality because it serves as a substantial, if not dominant, carrier of various water-quality constituents including nutrients and trace elements (Feltz, 1980; Horowitz, 1991; Vaithiyanathan and Correll, 1992; Miller and Orbock Miller, 2007). Deposited sediment may act as a sink for various constituents and, under certain conditions, as a source of constituents to the overlying water column and biota (Forstner and Wittmann, 1981; Baudo and others, 1990; Zoumis and others, 2001; Brower and Cecchine, 2002). Previous studies have provided evidence for a relation between the concentration of constituents (phosphorus, selected trace elements) in stream water and streambed sediment (Feltz, 1980; Klotz, 1991; Haggard and others, 2007). Thus, streambed sediment may provide an indication of water quality for certain constituents. Moreover, streambed sediment may provide a means of identifying priority subbasins for TMDL development and BMP implementation.

A 2-year study by the U.S. Geological Survey (USGS), in cooperation with the Kansas Department of Health and Environment (KDHE), was begun in 2006 to investigate streambed-sediment quality throughout the Little Arkansas River Basin and assess its relation to historical water quality. The specific study objectives were to:

1. Determine streambed-sediment quality for selected mainstem and tributary sites throughout the Little Arkansas River Basin;

2. Assess and interpret the spatial and temporal variability in streambed-sediment quality in relation to basin characteristics;

3. Investigate the use of streambed-sediment quality to estimate surface-water quality (for selected constituents) for all sites for which both types of data were available; and

4. Identify contaminant source areas in the basin to help guide BMP implementation.

\section{Purpose and Scope}

The purpose of this report is to present the results of the USGS study to assess streambed-sediment quality and its relation to historical water quality in the Little Arkansas River
Basin. In 2007, streambed-sediment samples were collected at 26 main-stem and tributary sites throughout the basin and analyzed for selected chemical constituents. The sedimentchemical data were compared to historical water-quality data, available from KDHE and USGS at eight sites, to investigate the possibility of using sediment quality to estimate surfacewater quality. Results presented in this report will assist KDHE in the development, evaluation, and implementation of TMDLs for constituents determined to contribute to waterquality impairment in the Little Arkansas River Basin. From a national perspective, the methods and results presented provide guidance and perspective for future studies concerned with the issues of sediment-quality variability, the relation between sediment and water quality, and source determination for sediment and sediment-associated constituents.

\section{Description of Little Arkansas River Basin}

The Little Arkansas River Basin is an area of about 1,420 square miles $\left(\mathrm{mi}^{2}\right)$ that drains part of south-central Kansas (fig. 1). Major tributaries to the Little Arkansas River include Black Kettle, Blaze Fork, Emma, Jester, Kisiwa, Sand, and Turkey Creeks (fig. 2). The Little Arkansas River is a tributary to the Arkansas River, with the confluence located within the city of Wichita.

Physiographically, the basin can be characterized with reference to physical divisions as defined by Fenneman (1946) and Schoewe (1949) (fig. 1). Most of the basin is located within the Central Lowland Province of the Interior Plains (Fenneman, 1946). Within the Central Lowland Province, most of the basin is located within the Arkansas River Lowlands Section. Exceptions include the extreme eastern part of the basin which is located within the Flint Hills Upland division of the Osage Plains Section, and some of the extreme northwest part of the basin which is located within the Smoky Hills division of the Dissected High Plains Section (Great Plains Province). Within the Arkansas River Lowlands Section, the basin is located partly in the Great Bend Lowland and partly in the McPherson Lowland divisions (fig. 1). The Great Bend and McPherson Lowlands are similar in that both have generally flat terrain with little relief. Surface materials mostly consist of unconsolidated deposits of gravel, sand, silt, and clay of Tertiary or Quaternary age (Schoewe, 1949).

Long-term, mean annual precipitation in the Little Arkansas River Basin is about 30 inches (in.) at both McPherson, Kansas (period of record 1900-2006), in the northern part of the basin, and Sedgwick, Kansas (period of record 19482006), in the south (High Plains Regional Climate Center, 2007) (fig. 2). Most of the annual precipitation occurs during the growing season (generally April-September).

Land use (1988-90) in the Little Arkansas River Basin is mostly agricultural with cropland and grassland accounting for about 77 and 20 percent of the basin, respectively. Urban land use occupies about 2 percent of the basin. Cities located partly or completely within the basin include Hutchinson, 


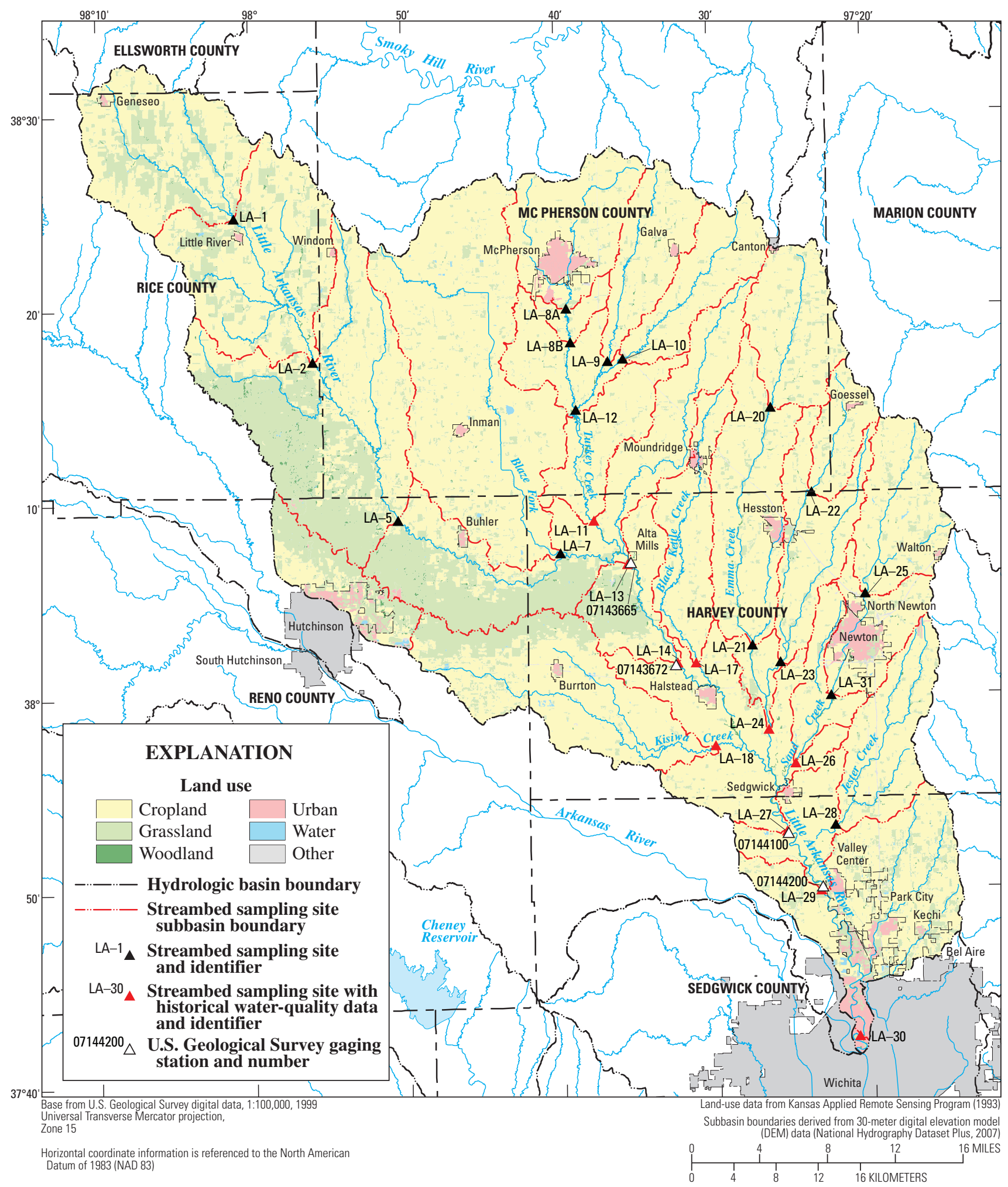

Figure 2. Land use in the Little Arkansas River Basin (1988-90) and location of streambed-sediment sampling sites (source of land-use data: Kansas Applied Remote Sensing Program, 1993). 


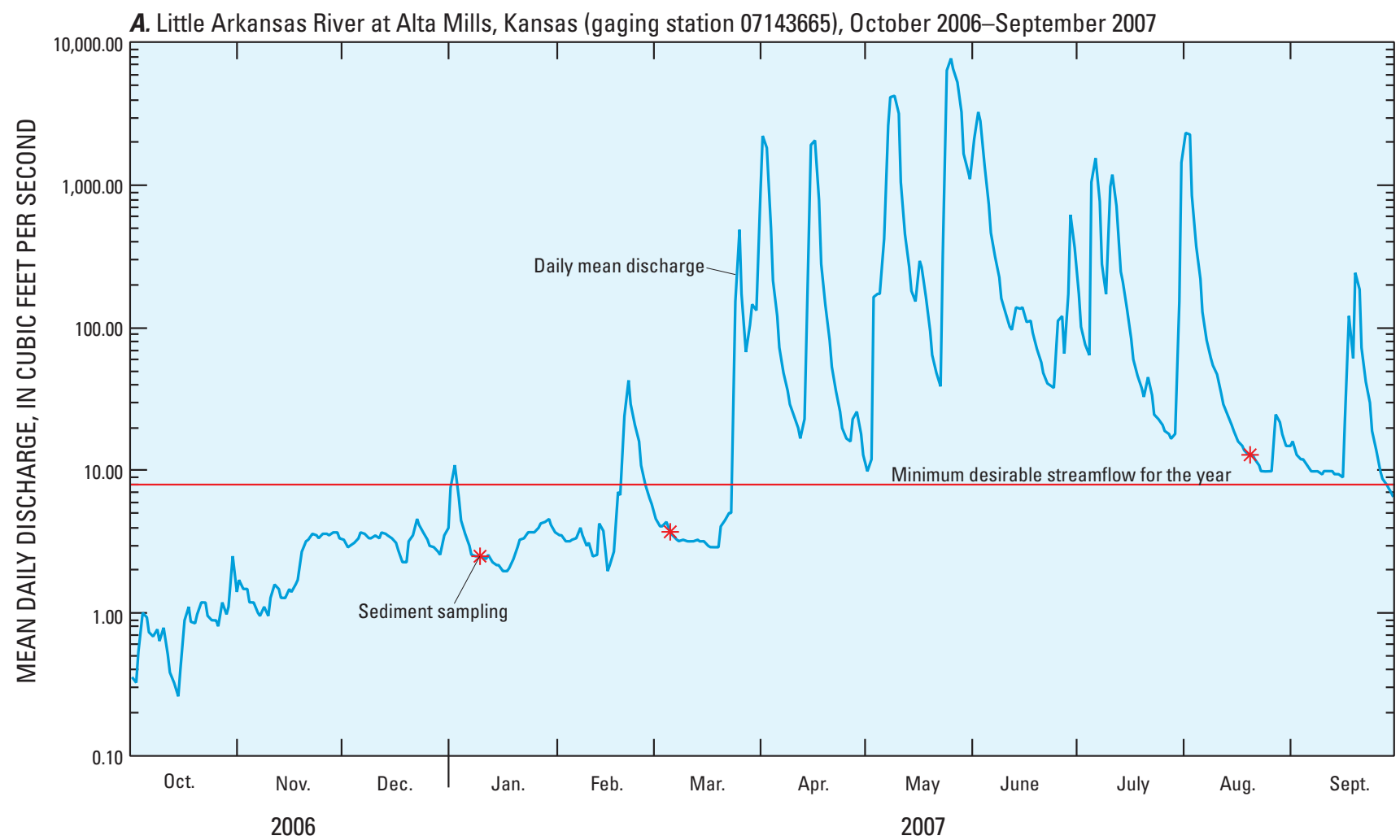

B. Little Arkansas River at Valley Center, Kansas (gaging station 07144200), October 2006-September 2007

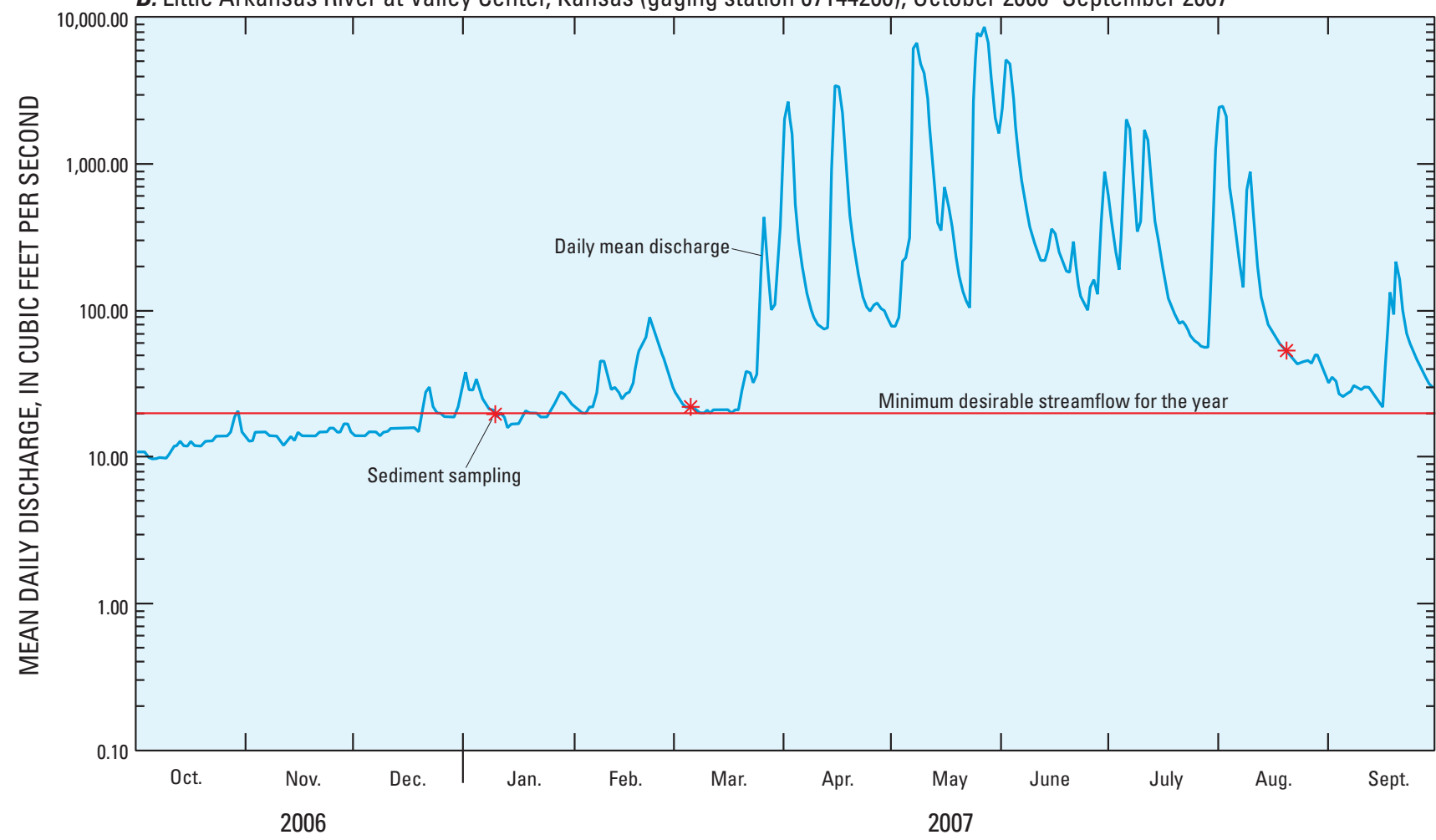

Figure 3. Mean daily streamflow from October 1, 2006 to September 30, 2007 for (A) Little Arkansas River at Alta Mills, Kansas, and (B) Little Arkansas River at Valley Center, Kansas. 
McPherson, Newton, and Wichita. Woodland accounts for about 1 percent of the basin (fig. 2) (Kansas Applied Remote Sensing Program, 1993).

\section{Methods}

The objectives of this study were accomplished using historical and newly collected information. Historical information included water-quality data previously collected by KDHE and USGS for eight sites within the Little Arkansas River Basin (water-quality data from two other KDHE sites were not used because of an insufficient number of samples). New information was obtained through the collection and analysis of streambed-sediment samples, the methods for which are described in this section.

\section{Site Selection}

Sites for streambed-sediment sampling were selected to be representative of conditions in the subbasins throughout the Little Arkansas River Basin. Also, sites were selected that had available water-quality data from KDHE (sites LA-11, LA-13, LA-17, LA-18, LA-24, LA-26, LA-29, and LA-30) or USGS (sites LA-14 and LA-27). Four sites (LA-13, LA-14, LA-27, and LA-29) are located at currently (2008) active USGS stream-gaging stations. The location of the sampling sites is provided in figure 2 . The latitude and longitude for all sampling sites, obtained using global positioning system (GPS) technology, are provided in table A1 in the "Supplemental Information" section at the back of this report.

\section{Sample Collection and Preparation}

Within the Little Arkansas River Basin, streambedsediment samples were collected at 26 sites (fig. 2) during low-flow conditions. The initial samples, hereafter referred to as the winter samples, were collected in either January or March of 2007 (table A1). Also, to assess temporal variability in sediment quality, eight sites (LA-11, LA-13, LA-14, LA-23, LA-24, LA-26, LA-27, and LA-29) were resampled in August 2007. These eight samples are hereafter referred to as the summer samples. Whereas streamflow in the basin was low with minimal variability before and between the two winter sampling dates, several large flows occurred between the last winter sampling date and the summer sampling date (fig. 3). Simultaneous water-quality samples were not collected with the streambed-sediment samples because information on historical water-quality for a range of flow conditions already was available and assumed to be representative.
At each site, streambed sediment was collected to a depth of about $0.4 \mathrm{in}$. at about 10 locations within the channel to obtain a composite sample of recently deposited bed material. The material was collected using a handheld plastic scoop, placed in a plastic bag, and transported back to the USGS laboratory in Lawrence, Kansas, for subsequent sample preparation.

Each sample was emptied from the plastic bag into a clean glass bowl for examination and removal of unwanted components (for example, grass, sticks, leaves, and rocks). Following homogenization, each sample was placed in a small plastic jar for subsequent shipment to other laboratories for additional preparation and constituent analyses.

All samples were sieved to isolate the less than 63-micron $(\mu \mathrm{m})$ fraction (that is, the silt and clay) for chemical analyses. This step was required to minimize potential bias in constituent concentrations that could be attributable to differences in the amount of coarse particles (for example, sand) in the samples. Also, the less than $63-\mu \mathrm{m}$ fraction is important because it is the most chemically active fraction of sediment (Horowitz, 1991). The samples were wet sieved at the USGS Sediment Trace Element Partitioning Laboratory in Atlanta, Georgia, according to the methods presented in Guy (1969). Additionally, the sieved samples were analyzed for clay content at the USGS Earth Surface Processes Soils Laboratory in Denver, Colorado, using a laser analyzer (Harland Goldstein, USGS, written commun., 2007). Clay was defined as particles less than or equal to $3.9 \mu \mathrm{m}$ in size (Wentworth, 1922).

For bacteria analyses, streambed-sediment samples were collected from eight sites (LA-8A, LA-11, LA-13, LA-14, LA-24, LA-26, LA-27, and LA-29) during low-flow conditions in September 2007 (table A1). At each site, streambed sediment was sampled to a depth of less than $0.4 \mathrm{in}$. at about 10 locations within the channel to obtain a composite sample of recently deposited bed material (Myers and others, 2007). The sample was collected using a handheld plastic scoop. Each sample was placed in a 1-liter, autoclaved plastic bottle and transported back to the USGS laboratory in Lawrence, Kansas, for subsequent shipment to another USGS laboratory for preparation and analyses.

\section{Constituent Analyses}

The streambed-sediment samples were analyzed for nutrients (total nitrogen and total phosphorus), organic and total carbon, 25 trace elements, the radionuclides beryllium-7 ( $\left.{ }^{7} \mathrm{Be}\right)$, cesium-137 $\left({ }^{137} \mathrm{Cs}\right)$, lead-210 $\left({ }^{210} \mathrm{~Pb}\right)$, and radium-226 $\left.{ }^{226} \mathrm{Ra}\right)$, and bacteria (eight sites only). A complete list of the constituents for which analyses were performed is provided in table 1 . Analyses of sediment samples for nutrients, carbon, and trace elements were performed at the USGS Sediment Trace Element Partitioning Laboratory in Atlanta, Georgia. Analyses for total nitrogen and carbon concentrations were performed 
Table 1. Analyses performed on streambed-sediment samples from the Little Arkansas River Basin, south-central Kansas.

[Number in parentheses is the method reporting limit for each constituent. $\mathrm{mg} / \mathrm{kg}$, milligrams per kilogram; \%, percent dry weight; dpm/g, disintegrations per minute per gram; $\mathrm{pCi} / \mathrm{g}$, picocuries per gram; $\mathrm{col} / \mathrm{g}_{\mathrm{DW}}$, colonies per gram (dry weight)]

\begin{tabular}{|c|c|c|c|}
\hline \multicolumn{4}{|c|}{ Nutrients } \\
\hline Total nitrogen $(100 \mathrm{mg} / \mathrm{kg})$ & \multicolumn{3}{|l|}{ Total phosphorus (50 mg/kg) } \\
\hline \multicolumn{4}{|c|}{$\begin{array}{ll}\text { Carbon } \\
\end{array}$} \\
\hline \multicolumn{4}{|c|}{ Trace elements } \\
\hline Aluminum $(0.1 \%)$ & Cobalt $(1.0 \mathrm{mg} / \mathrm{kg})$ & Nickel $(1.0$ mg/kg) & Titanium $(0.01 \%)$ \\
\hline Arsenic $(0.1 \mathrm{mg} / \mathrm{kg})$ & Iron $(0.1 \%)$ & Silver $(0.5$ mg/kg) & Vanadium (1.0 mg/kg) \\
\hline Barium (1.0 mg/kg) & Lead $(1.0 \mathrm{mg} / \mathrm{kg})$ & Strontium $(1.0 \mathrm{mg} / \mathrm{kg})$ & Zinc $(1.0 \mathrm{mg} / \mathrm{kg})$ \\
\hline Beryllium (0.1 mg/kg) & Lithium $(1.0 \mathrm{mg} / \mathrm{kg})$ & Sulfur $(0.01 \%)$ & \\
\hline Cadmium (0.1mg/kg) & Manganese $(10.0 \mathrm{mg} / \mathrm{kg})$ & Thallium (50 mg/kg) & \\
\hline \multicolumn{4}{|c|}{ Bacteria $^{1}$} \\
\hline Enterococci $\left(\mathrm{col} / \mathrm{g}_{\mathrm{DW}}\right)$ & Escherichia coli $\left(\mathrm{col} / \mathrm{g}_{\mathrm{DW}}\right)$ & Fecal coliform $\left(\mathrm{col} / \mathrm{g}_{\mathrm{DW}}\right)$ & Total coliform $\left(\mathrm{col} / \mathrm{g}_{\mathrm{DW}}\right)$ \\
\hline
\end{tabular}

using the methods described by Horowitz and others (2001). Analyses for total phosphorus and trace elements were performed using the methods described by Fishman and Friedman (1989), Arbogast (1996), and Briggs and Meier (1999).

Radionuclide analyses were performed at a USGS laboratory in Menlo Park, California. Analyses for ${ }^{7} \mathrm{Be},{ }^{137} \mathrm{Cs}$, ${ }^{210} \mathrm{~Pb}$, and ${ }^{226} \mathrm{Ra}$ were performed using the methods described by Robbins and Edgington (1975), Olsen and others (1986), and Fuller and others (1999).

Bacteria analyses were performed at the USGS microbiology laboratory in Columbus, Ohio. In the methods used, the sediment was isolated from the original pore water to the extent possible. The remaining pore water had an unknown affect on the results. Specifically, the streambed-sediment samples were analyzed for enterococci, Escherichia coli (E. coli), fecal coliform, and total coliform according to the methods described by Britton and Greeson (1989), Eaton and others (2005), and Myers and others (2007).

\section{Quality Control}

Quality control for the chemical analyses of streambedsediment samples was provided by an evaluation of analytical and spatial variability. Analytical variability was evaluated through the split-replicate analysis of a single sediment sample collected at two sites (LA-14 and LA-30) (fig. 2). Each sample was homogenized and sampled twice to obtain the split-replicate samples. Spatial (within-site) variability was evaluated by the collection and analysis of sequential-replicate samples at two sites (LA-2 and LA-27) (fig. 2). That is, the sequentialreplicate samples were obtained by collecting two separate samples at each site. Individual sequential-replicate samples were homogenized prior to analysis. All split- and sequentialreplicate samples were analyzed for the various chemical constituents.

For each pair of samples, the relative percentage difference between the replicate sample concentrations or activities was computed as:

$$
\mathrm{D}_{\mathrm{rp}}=[|\mathrm{C} 1-\mathrm{C} 2| /(\mathrm{C} 1+\mathrm{C} 2)] * 100,
$$

where $\mathrm{D}_{\mathrm{rp}}$ is the relative percentage difference, $\mathrm{C} 1$ is the first replicate sample concentration or activity, and $\mathrm{C} 2$ is the second replicate sample concentration or activity.

The relative percentage differences computed for all constituents detected in the split- and sequential-replicate samples are provided in table 2 . With the exception of selenium, tin, and cesium-137, analytical variability for the split-replicate samples was minimal with mean relative percentage differences less than 6 percent. Selenium, tin, and cesium-137 had mean relative percentage differences of $8.4,10$, and 16.4 percent, respectively. With the exception of total organic carbon, cadmium, selenium, and tin, spatial variability for the sequential-replicate samples also was minimal with mean relative percentage differences of about 9 percent or less. Total organic carbon, cadmium, selenium, and tin had respective 
mean relative percentage differences of $11.3,19.3,10.1$, and 16.7 percent.

Quality control for the bacteria analyses was provided by the analysis of split-replicate samples for site LA-24 and sequential-replicate samples for site LA-13 (fig. 2). The relative percentage differences (determined for $E$. coli and fecal coliform) averaged about 28 percent for the split-replicate samples and about 23 percent for the sequential-replicate samples (table 2).

\section{Sediment-Quality Guidelines}

The U.S. Environmental Protection Agency (USEPA) has adopted nonenforceable sediment-quality guidelines (SQGs) for freshwater systems in the form of level-of-concern concentrations for several trace elements (U.S. Environmental Protection Agency, 1997). These level-of-concern concentrations were derived from biological-effects correlations made on the basis of paired onsite and laboratory data to relate the incidence of adverse biological effects in aquatic organisms to dry-weight sediment concentrations. Two such level-ofconcern guidelines adopted by USEPA are referred to as the threshold-effects level (TEL) and the probable-effects level (PEL). The TEL is assumed to represent the concentration below which toxic biological effects rarely occur. In the range of concentrations between the TEL and PEL, toxic effects occasionally occur. Toxic effects usually or frequently occur at concentrations above the PEL.

USEPA cautions that the TEL and PEL guidelines are intended for use as screening tools for possible hazardous levels of chemicals and are not regulatory criteria. This cautionary statement is made because, although biological-effects correlation identifies level-of-concern concentrations associated with the likelihood of adverse organism response, the comparison may not demonstrate that a particular chemical is solely responsible. In fact, biological-effects correlations may not indicate direct cause-and-effect relations because sediments may contain a mixture of chemicals that contribute to the adverse effects to some degree. Thus, for any given site, these guidelines may be over- or underprotective (U.S. Environmental Protection Agency, 1997).

MacDonald and others (2000) developed consensusbased SQGs for freshwater systems that were computed as the geometric mean of several previously published SQGs. The consensus-based SQGs consist of a threshold-effect concentration (TEC) and a probable-effect concentration (PEC). The TEC represents the concentration below which adverse effects are not expected to occur, whereas the PEC represents the concentration above which adverse effects are expected to occur more often than not. An evaluation of the reliability of the SQGs indicated that most of the individual TECs and PECs provide an accurate basis for predicting the presence or absence of sediment toxicity (MacDonald and others, 2000).

A comparison of the two SQGs indicated that the differences generally were small (table 3 ). The largest difference was for the zinc PEL and PEC. In this case, the PEC (459 mg/kg) was about 69 percent larger than the PEL $(271 \mathrm{mg} / \mathrm{kg})$. For this study, the SQGs used were selected to provide a less-stringent assessment. Thus, for each trace element for which SQGs were available, the larger of the two options for threshold effects and probable effects was selected for the purpose of assessing sediment quality (table 3 ). In this report, the options used to assess sediment quality are referred to as the threshold-effects guideline and the probableeffects guideline.

\section{Statistical Analyses}

Correlation analyses were used to assess relations between constituents and between constituents and basin characteristics. Measures of correlation are dimensionless and scaled to be in the range of -1.0 to 1.0. A value of 0 indicates no relation between two variables. A value between 0 and -1.0 indicates a negative correlation (that is, one variable decreases as the other variable increases) whereas a value between 0 and 1.0 indicates a positive correlation (that is, one variable increases as the other variable increases). In this study, Spearman's rho correlation coefficients were computed with a 0.10 level of significance. An advantage of Spearman's rho is that, because it is based on ranks, it is more resistant to outlier effects than the more commonly used Pearson's r correlation coefficient (Helsel and Hirsch, 1992). Correlations were considered to be significantly positive or negative if the probability (two-sided p-value) of rejecting a correct hypothesis (in this case, no relation) was less than or equal to 0.10 .

\section{Comparison of Water Quality to Sediment Quality}

Investigation of the relation of water quality to streambed-sediment quality in the Little Arkansas River Basin involved a comparison for sites where both types of data were available (sites LA-11, LA-13, LA-14, LA-24, LA-26, LA-27, LA-29, and LA-30; fig. 2). As part of the analysis, water quality and sediment quality also were compared with streamflow. In this study, the comparison was focused on nitrogen $(\mathrm{N})$, phosphorus $(\mathrm{P})$, and organic carbon (OC).

Historical water-quality data from KDHE were available for six sampling sites (LA-11, LA-13, LA-24, LA-26, LA-29, and LA-30; fig. 2). Only KDHE sites with at least 10 samples analyzed were included (sites LA-17 and LA-18 were excluded because they only had six and one sample(s) analyzed, respectively). Available data used for the six KDHE sites date back to 1995 . The number of samples analyzed per site ranged from 10 to 58 (table 4). Historical water-quality data from the USGS were available for sampling sites LA-14 and LA-27 (fig. 2). Available data used for the USGS sites date back to 1995 . The number of samples analyzed per site ranged from 59 to 73 (table 4). 
Table 2. Relative percentage differences for constituent concentrations or activities and bacteria densities in split-replicate and sequential-replicate streambed-sediment samples from the Little Arkansas River Basin, south-central Kansas.

[Location of sampling sites shown in figure 2. --, not available or not calculated because constituent was not detected in one or both of the samples]

\begin{tabular}{|c|c|c|c|c|c|c|}
\hline \multirow{3}{*}{ Constituent } & \multicolumn{6}{|c|}{ Relative percentage difference } \\
\hline & \multicolumn{3}{|c|}{ Split-replicate samples ${ }^{1}$} & \multicolumn{3}{|c|}{ Sequential-replicate samples ${ }^{2}$} \\
\hline & Site LA-14 & Site LA-30 & Mean & Site LA-2 & Site LA-27 & Mean \\
\hline Total nitrogen & 1.6 & 7.5 & 4.6 & 4.3 & 12.6 & 8.5 \\
\hline Total phosphorus & 0 & 0 & 0 & 3.2 & 2.2 & 2.7 \\
\hline Carbon (total organic) & 0 & 3.4 & 1.7 & 8.3 & 14.3 & 11.3 \\
\hline Carbon (total) & 3.8 & 1.5 & 2.7 & 3.7 & 12.3 & 8.0 \\
\hline \multicolumn{7}{|c|}{ Trace elements } \\
\hline Aluminum & 0 & 1.1 & .6 & 3.4 & 2.7 & 3.1 \\
\hline Beryllium & 0 & 0 & 0 & 2.7 & 0 & 1.4 \\
\hline Cadmium & 6.7 & 0 & 3.4 & 0 & 38.5 & 19.3 \\
\hline Chromium & 1.9 & 1.3 & 1.6 & 1.1 & 0 & .6 \\
\hline Cobalt & 0 & 0 & 0 & 4.3 & 4.3 & 4.3 \\
\hline Copper & 0 & 0 & 0 & 6.3 & 0 & 3.2 \\
\hline Iron & 1.6 & 2.4 & 2.0 & 4.3 & 2.2 & 3.3 \\
\hline Lead & 0 & 0 & 0 & 4.5 & 4.5 & 4.5 \\
\hline Silver & -- & -- & -- & -- & -- & -- \\
\hline Strontium & 2.9 & 1.3 & 2.1 & 0 & 0 & 0 \\
\hline Sulfur & -- & 0 & -- & 0 & -- & -- \\
\hline Thallium & -- & -- & -- & -- & -- & -- \\
\hline Tin & 0 & 20.0 & 10.0 & 0 & 33.3 & 16.7 \\
\hline Titanium & 1.2 & 0 & .6 & 1.3 & 1.2 & 1.3 \\
\hline Uranium & -- & -- & -- & -- & -- & -- \\
\hline Vanadium & .6 & .9 & .8 & 4.1 & 2.2 & 3.2 \\
\hline Zinc & .6 & 0 & .3 & 8.1 & 2.0 & 5.1 \\
\hline
\end{tabular}


Table 2. Relative percentage differences for constituent concentrations or activities and bacteria densities in split-replicate and sequential-replicate streambed-sediment samples from the Little Arkansas River Basin, south-central Kansas. - Continued

[Location of sampling sites shown in figure 2. --, not available or not calculated because constituent was not detected in one or both of the samples]

\begin{tabular}{|c|c|c|c|c|c|c|}
\hline \multirow{3}{*}{ Constituent } & \multicolumn{6}{|c|}{ Relative percentage difference } \\
\hline & \multicolumn{3}{|c|}{ Split-replicate samples ${ }^{1}$} & \multicolumn{3}{|c|}{ Sequential-replicate samples ${ }^{2}$} \\
\hline & Site LA-14 & Site LA-30 & Mean & Site LA-2 & Site LA-27 & Mean \\
\hline Beryllium-7 & 9.3 & 1.9 & 5.6 & -- & 1.5 & -- \\
\hline Cesium-137 & 11.1 & 21.7 & 16.4 & 7.7 & 11.1 & 9.4 \\
\hline Radium-226 & 1.1 & 2.9 & 2.0 & 2.6 & 1.7 & 2.2 \\
\hline \multicolumn{7}{|c|}{ Bacteria $^{3}$} \\
\hline Escherichia coli & 25.7 & -- & -- & 10.3 & -- & -- \\
\hline Fecal coliform & 30.2 & -- & -- & 36.0 & -- & -- \\
\hline
\end{tabular}

${ }^{1}$ Split-replicate samples were obtained by homogenizing the sediment collected at each site and sampling it twice.

${ }^{2}$ Sequential-replicate samples were obtained by collecting two separate sediment samples at each site.

${ }^{3}$ Split-replicate samples were analyzed for site LA-24 and sequential-replicate samples were analyzed for site LA-13. Relative percentage differences were not computed for total coliform and enterococci because the density for one or both samples was reported as "greater than" for each site. See table 7.

The KDHE and USGS water-quality samples differed with respect to the sampling and analytical techniques used. Samples collected by KDHE typically were single-point samples dipped near the surface of the water column. Samples collected by USGS were either single-point dip samples or composite samples collected by equal-width interval or equaldischarge increment techniques (U.S. Geological Survey, 2006). Samples collected by KDHE were analyzed for total suspended solids concentration (TSS), whereas the USGS samples were analyzed for TSS and suspended sediment concentration (SSC). TSS and SSC are not interchangeable and there can be a large difference between the two for a given sample (Gray and others, 2000).

Water-quality samples collected by KDHE were analyzed using the methods described by the U.S. Environmental Protection Agency $(1982,1983)$ and the American Public Health Association (1998). Water-quality samples collected by USGS were analyzed using the methods described by Guy (1969), Fishman and Friedman (1989), Patton and Truitt (1992), Fishman (1993), and Patton and Kryskalla (2003).

To enable the comparison, particulate $\mathrm{N}$ concentration was computed by subtracting the ammonia (dissolved nitrogen) concentration from the total Kjeldahl nitrogen concentration for each water-quality sample. Also, particulate $\mathrm{P}$ concentration was computed by subtracting the ortho-phosphorus (dissolved) concentration from the total phosphorus concentration for each water-quality sample. The resultant estimates of particulate $\mathrm{N}$ and $\mathrm{P}$ concentrations for the water samples were more directly comparable with the $\mathrm{N}$ and $\mathrm{P}$ concentrations determined for the streambed-sediment samples. Because the $\mathrm{N}$ and $\mathrm{P}$ concentrations in the sediment samples essentially represent particulate concentrations, they are referred to as particulate concentrations in this report. Organic carbon concentrations in the water and sediment samples were considered to be particulate concentrations.

Before a comparison between the water-quality and sediment-quality data for each site was attempted, additional modification of the data sets was necessary to make the data sets more directly comparable. Particulate N, P, and OC concentrations for the KDHE and USGS water-quality samples were normalized by dividing by TSS to correct for differing amounts of TSS in the samples. Particulate N, P, and OC concentrations for the streambed-sediment samples were normalized by dividing by the percentage of clay to correct for differing amounts of clay in the samples. This correction required the assumption that most of the particulate $\mathrm{N}, \mathrm{P}$, and $\mathrm{OC}$ were contained in the clay fraction of the sediment samples. A graphical comparison for each site was achieved by plotting the normalized water-quality and sediment-quality data in relation to discharge.

\section{Sediment Quality in the Little Arkansas River Basin}

In this section, the spatial and temporal variability in streambed-sediment concentrations of selected chemical constituents is discussed. A constituent was selected if it was detected in the sediment samples collected by USGS and it frequently or typically was detected in the water samples collected by KDHE. On the basis of these criteria, particulate $\mathrm{N}$, particulate $\mathrm{P}$, particulate $\mathrm{OC}$, and 14 trace elements were evaluated. Radionuclides and bacteria also are discussed. 
Table 3. Sediment-quality guidelines for selected trace elements and associated bioaccumulation index.

[Values in milligrams per kilogram. Shading represents guidelines to which sediment concentrations were compared in this report. USEPA, U.S. Environmental Protection Agency; TEL, threshold-effects level; PEL, probable-effects level; TEC, threshold-effects concentration; PEC, probable-effects concentration; ,-- not available]

\begin{tabular}{|c|c|c|c|c|c|}
\hline \multirow{2}{*}{ Trace element } & \multicolumn{2}{|c|}{ USEPA (1997) } & \multicolumn{2}{|c|}{ MacDonald and others (2000) } & \multirow{2}{*}{$\begin{array}{c}\text { Bio-accumulation } \\
\text { index }\end{array}$} \\
\hline & TEL & PEL & TEC & PEC & \\
\hline Arsenic & 7.24 & 41.6 & 9.79 & 33.0 & moderate \\
\hline Cadmium & .676 & 4.21 & .99 & 4.98 & moderate \\
\hline Chromium & 52.3 & 160 & 43.4 & 111 & moderate \\
\hline Copper & 18.7 & 108 & 31.6 & 149 & high \\
\hline Lead & 30.2 & 112 & 35.8 & 128 & moderate \\
\hline Nickel & 15.9 & 42.8 & 22.7 & 48.6 & moderate \\
\hline Silver & .733 & 1.77 & -- & -- & moderate \\
\hline Zinc & 124 & 271 & 121 & 459 & high \\
\hline
\end{tabular}

'Bioaccumulation index information for trace elements from Pais and Jones (1997).

Table 4. Water-quality sampling sites included in this study.

[N, nitrogen; P, phosphorus; OC, organic carbon]

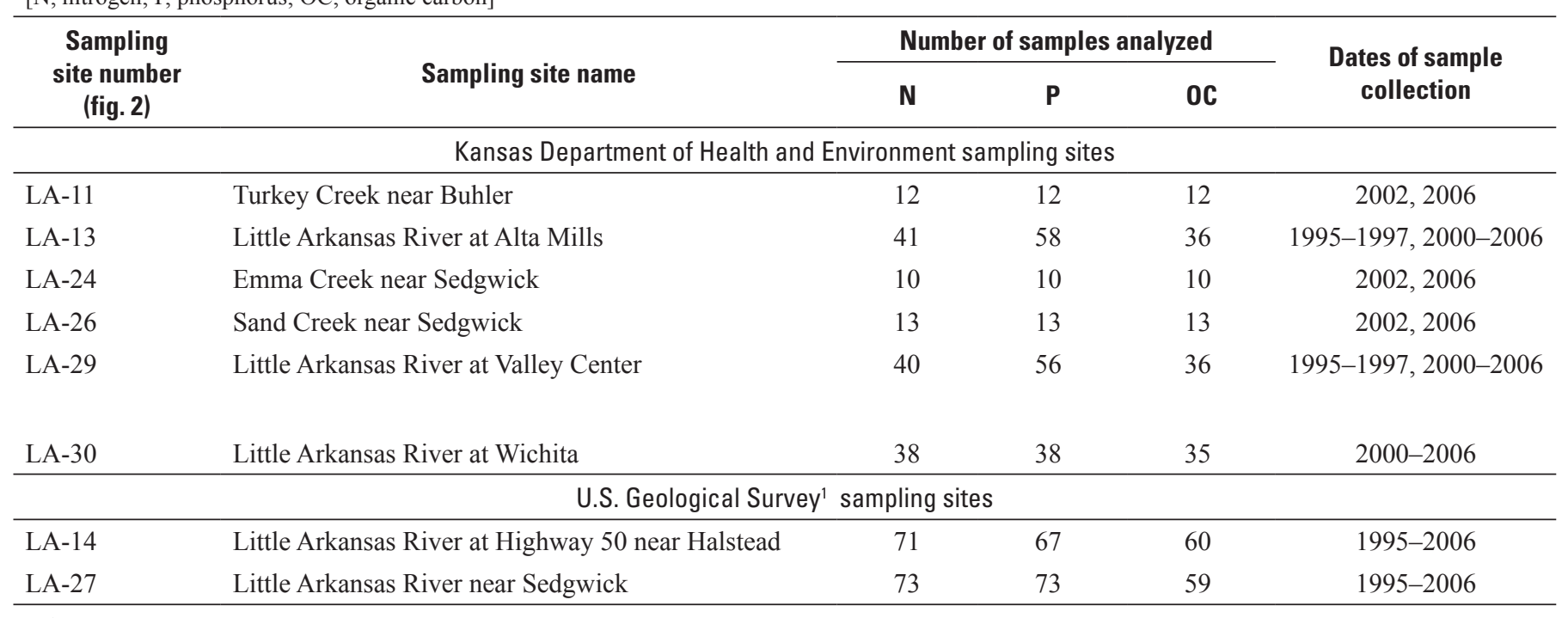

${ }^{1}$ Dates of sample collection for $\mathrm{N}$ and $\mathrm{P}$ were 2000-2006.

\section{Nutrients and Organic Carbon}

Site-to-site variability in constituent concentrations was substantial for the winter sediment samples, and order-of-magnitude differences were measured for particulate $\mathrm{N}$ (tables 5, A2). Particulate $\mathrm{N}$ concentrations in the winter samples ranged from 700 milligrams per kilogram $(\mathrm{mg} / \mathrm{kg}$ ) (site LA-7) to $8,000 \mathrm{mg} / \mathrm{kg}$ (site LA-23). Particulate P concentrations in the winter samples also varied considerably with a range of $330 \mathrm{mg} / \mathrm{kg}$ (site LA-11) to $2,300 \mathrm{mg} / \mathrm{kg}$ (sites LA-27 and LA-29) (tables 5, A2; fig. 4A,D).

The particulate nutrient concentrations in the winter samples exhibited several spatial patterns within the basin. For the purposes of this discussion, the follow- ing concentration classes were established for particulate $\mathrm{N}$ on the basis of natural breaks in the data set: low (less than $1,000 \mathrm{mg} / \mathrm{kg}$ ), moderate $(1,000$ to $2,500 \mathrm{mg} / \mathrm{kg})$, high $(2,600$ to $4,000 \mathrm{mg} / \mathrm{kg}$ ), and very high (greater than $4,000 \mathrm{mg} / \mathrm{kg}$ ). Along the main-stem Little Arkansas River, particulate $\mathrm{N}$ concentrations were moderate upstream from Alta Mills (sites LA-1, LA-2, LA-5) and high to very high at and downstream from Alta Mills (sites LA-13, LA-14, LA-27, LA-29, LA-30) (fig. 4A, table A2). Among the tributaries sampled, particulate $\mathrm{N}$ concentrations were low for Blaze Fork (site LA-7), moderate for Black Kettle (site LA-17) and Jester (site LA-28) Creeks, low to high for Turkey Creek (sites LA-8A, LA-8B, LA-9, LA-10, LA-11, LA-12), moderate to high for Sand Creek (sites LA-25, LA-26, LA-31), high 
Table 5. Concentration and activity ranges for selected constituents in streambed-sediment samples collected in the Little Arkansas River Basin, south-central Kansas, January and March 2007.

[mg/kg, milligrams per kilogram; \%, percent; dpm/g, disintegrations per minute per gram; $\mathrm{pCi} / \mathrm{g}$, picocuries per gram]

\begin{tabular}{|c|c|c|}
\hline \multirow{2}{*}{ Constituent and unit of measurement } & \multicolumn{2}{|c|}{ Concentration } \\
\hline & Minimum (site(s), fig. 2) & Maximum (site(s), fig. 2) \\
\hline \multicolumn{3}{|c|}{ Nutrients } \\
\hline Total nitrogen, $\mathrm{mg} / \mathrm{kg}$ & 700 (LA-7) & 8,000 (LA-23) \\
\hline Total phosphorus, $\mathrm{mg} / \mathrm{kg}$ & $330($ LA-11) & 2,300 (LA-27, LA-29) \\
\hline \multicolumn{3}{|c|}{ Carbon } \\
\hline Total organic carbon, $\%$ & 0.7 (LA-7) & $5.8(\mathrm{LA}-23)$ \\
\hline \multicolumn{3}{|c|}{ Trace elements } \\
\hline Aluminum, $\%$ & 4.7 (LA-30) & $7.1(\mathrm{LA}-5)$ \\
\hline Antimony, mg/kg & $.5(\mathrm{LA}-27)$ & $.9(\mathrm{LA}-8 \mathrm{~B})$ \\
\hline Arsenic, mg/kg & $3.6(\mathrm{LA}-11)$ & $20(\mathrm{LA}-14)$ \\
\hline Barium, mg/kg & $610($ LA-30) & 940 (LA-22) \\
\hline Chromium, mg/kg & 37 (LA-11, LA-30) & 65 (LA-8B) \\
\hline Copper, $\mathrm{mg} / \mathrm{kg}$ & $11(\mathrm{LA}-11)$ & $60($ LA-31) \\
\hline Iron, $\%$ & $1.4(\mathrm{LA}-11)$ & 3.1 (LA-5, LA-29) \\
\hline Lead, $\mathrm{mg} / \mathrm{kg}$ & $16($ LA-11) & $51(\mathrm{LA}-31)$ \\
\hline Manganese, $\mathrm{mg} / \mathrm{kg}$ & 200 (LA-11) & $6,000(\mathrm{LA}-27)$ \\
\hline Nickel, mg/kg & $14(\mathrm{LA}-11)$ & 25 (LA-23) \\
\hline Selenium, $\mathrm{mg} / \mathrm{kg}$ & $.2(\mathrm{LA}-7, \mathrm{LA}-17)$ & $2.5($ LA-22) \\
\hline Strontium, mg/kg & $120($ LA-21) & $400($ LA-30) \\
\hline Vanadium, $\mathrm{mg} / \mathrm{kg}$ & $54($ LA-11) & 89 (LA-5) \\
\hline Zinc, mg/kg & $43(\mathrm{LA}-11)$ & $180($ LA-31) \\
\hline \multicolumn{3}{|c|}{ Radionuclides } \\
\hline Beryllium-7, dpm/g & $\begin{array}{c}<.4 \text { (LA-2, LA-8A, LA-9, } \\
\text { LA-11, LA-17) }\end{array}$ & $19.5(\mathrm{LA}-23)$ \\
\hline Cesium-137, pCi/g & $<.03$ (LA-11, LA-13) & $.32(\mathrm{LA}-18)$ \\
\hline Lead-210, dpm/g & $3.20(\mathrm{LA}-2)$ & $9.86(\mathrm{LA}-23)$ \\
\hline Radium-226, dpm/g & 1.90 (LA-22, LA-23) & 3.30 (LA-12) \\
\hline
\end{tabular}

for Kisiwa Creek (site LA-18), and moderate to very high for Emma Creek (sites LA-20, LA-21, LA-22, LA-23, LA-24). Within the Emma Creek subbasin, sites LA-22 and LA-23 had the largest particulate $\mathrm{N}$ content of all the sites sampled with respective concentrations of 5,600 and $8,000 \mathrm{mg} / \mathrm{kg}$ (fig. $4 A$, table A2).

Likewise, to facilitate the discussion of particulate $\mathrm{P}$ variability, the following concentration classes were set: low (less than $1,000 \mathrm{mg} / \mathrm{kg})$, moderate $(1,000$ to $1,500 \mathrm{mg} / \mathrm{kg})$, and high (greater than 1,500 mg/kg). Along the main-stem Little Arkansas River, particulate P concentrations were low upstream from Alta Mills and typically high at and downstream from Alta Mills (fig. 4D, table A2). Among the tributaries sampled, particulate $\mathrm{P}$ concentrations were low for Black Kettle, Blaze Fork, and Jester Creeks, low to moderate for Turkey Creek, low to high for Emma and Sand Creeks, and moderate for Kisiwa Creek (fig. 4D, table A2).

Overall, the spatial patterns of particulate $\mathrm{N}$ and $\mathrm{P}$ variability within the Little Arkansas River Basin were similar (fig. $4 A, D$ ) and the correlation between the particulate $\mathrm{N}$ and $\mathrm{P}$ concentrations was statistically significant (Spearman's rho $=0.87$, two-sided $\mathrm{p}$-value $=0.000)$. The correlation indicated that particulate $\mathrm{N}$ and $\mathrm{P}$ sediment concentrations likely were affected by the same factors within the basin. Variability of nutrient concentrations in sediment is due partly to the variability in natural sources (that is, soils and bedrock) within and between subbasins and also to the effects of human activity (for example, fertilizer application, septic systems, wastewater-treatment facilities, crop production, and livestock and poultry production). 
A. Particulate nitrogen

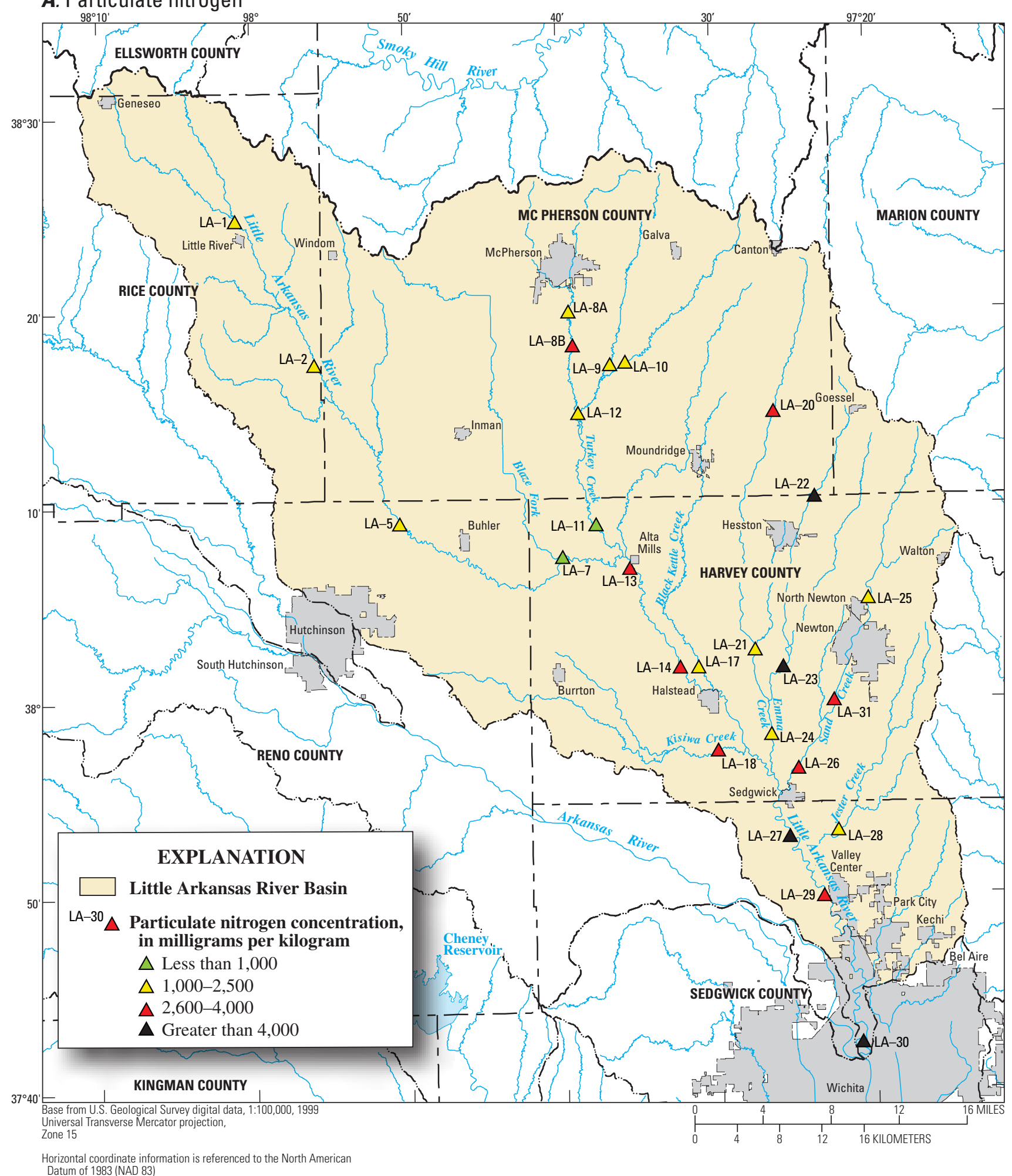

Figure 4. Original, clay-normalized, and organic-carbon-normalized concentrations of particulate nitrogen and phosphorus in streambed-sediment samples collected in the Little Arkansas River Basin, south-central Kansas, January and March 2007. 
B. Clay-normalized particulate nitrogen

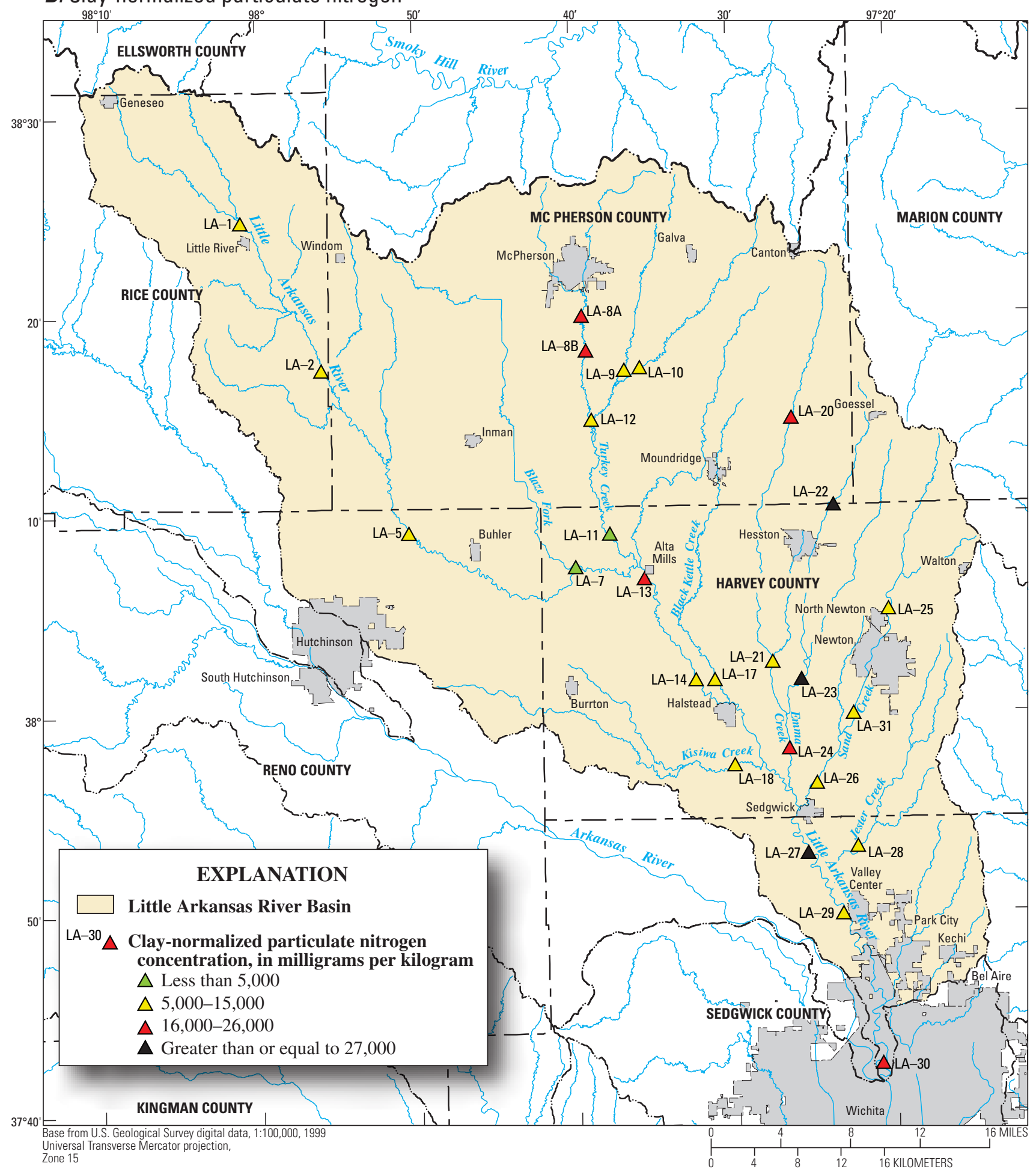

Horizontal coordinate information is referenced to the North American Datum of 1983 (NAD 83)

Figure 4. Original, clay-normalized, and organic-carbon-normalized concentrations of particulate nitrogen and phosphorus in streambed-sediment samples collected in the Little Arkansas River Basin, south-central Kansas, January and March 2007.-Continued 
C. Organic-carbon-normalized particulate nitrogen

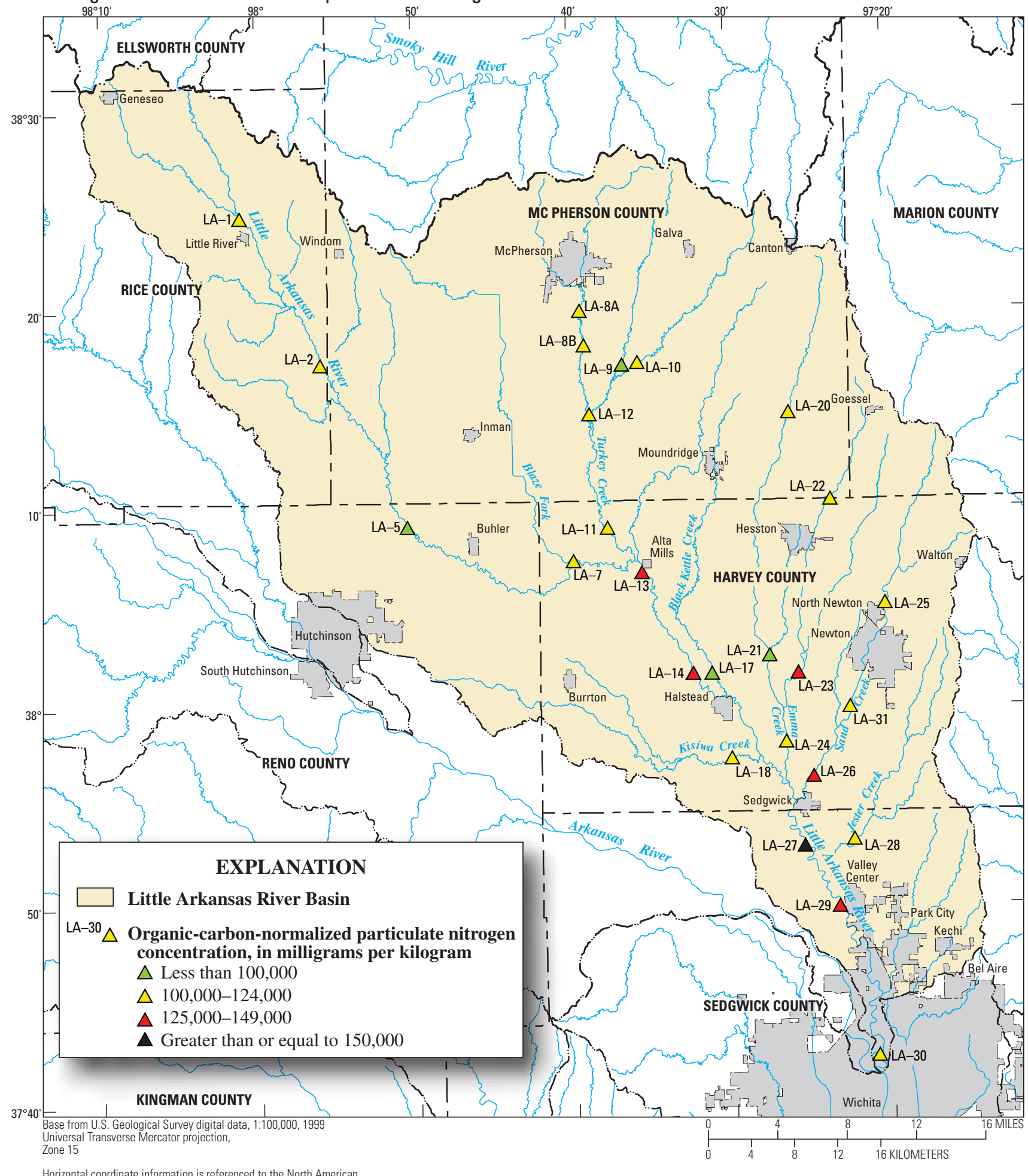

Horizontal coordinate information is referenced to the North American Datum of 1983 (NAD 83)

Figure 4. Original, clay-normalized, and organic-carbon-normalized concentrations of particulate nitrogen and phosphorus in streambed-sediment samples collected in the Little Arkansas River Basin, south-central Kansas, January and March 2007.-Continued 
D. Particulate phosphorus

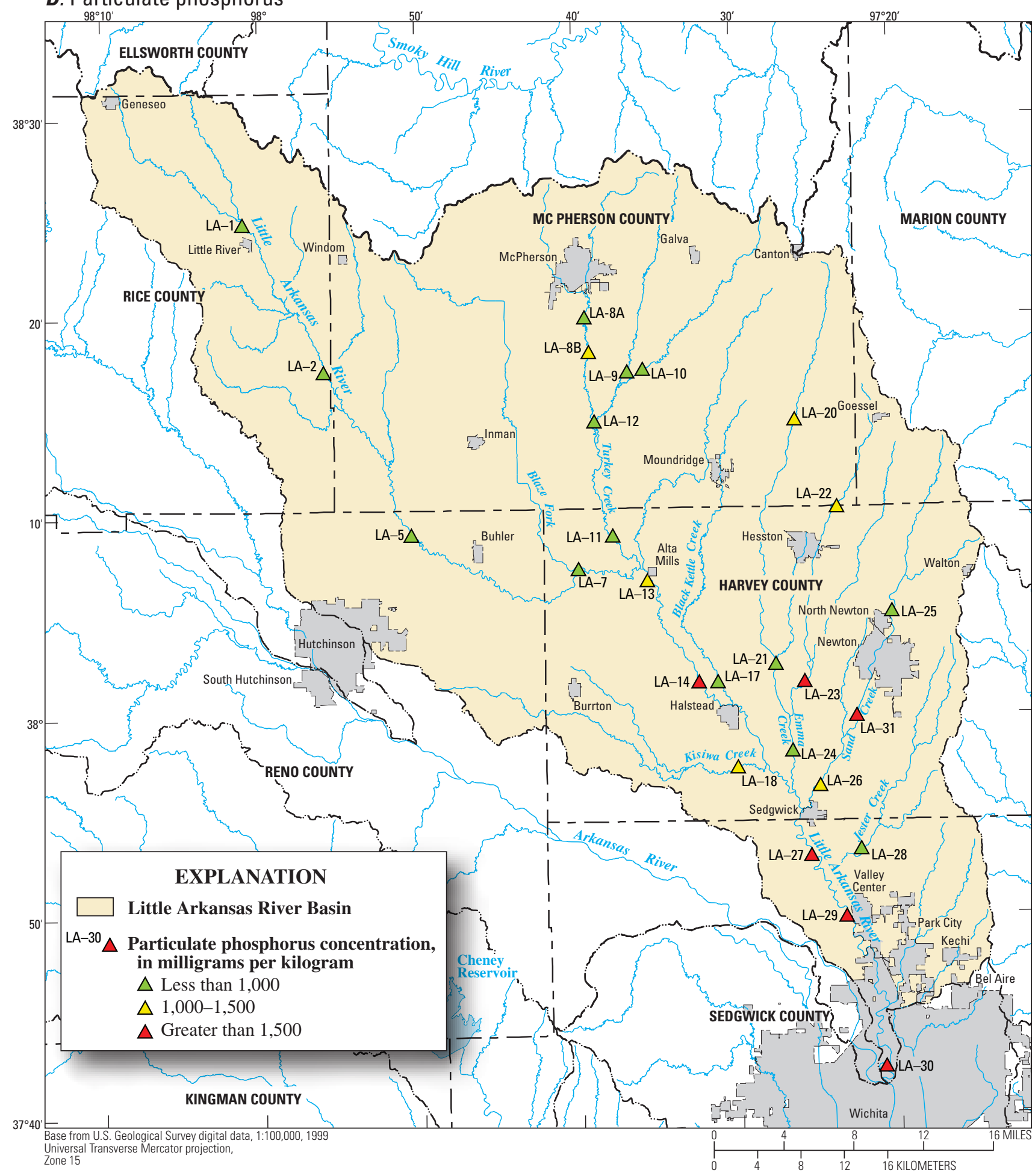

Horizontal coordinate information is referenced to the North American Datum of 1983 (NAD 83)

Figure 4. Original, clay-normalized, and organic-carbon-normalized concentrations of particulate nitrogen and phosphorus in streambed-sediment samples collected in the Little Arkansas River Basin, south-central Kansas, January and March 2007.-Continued 
E. Clay-normalized particulate phosphorus

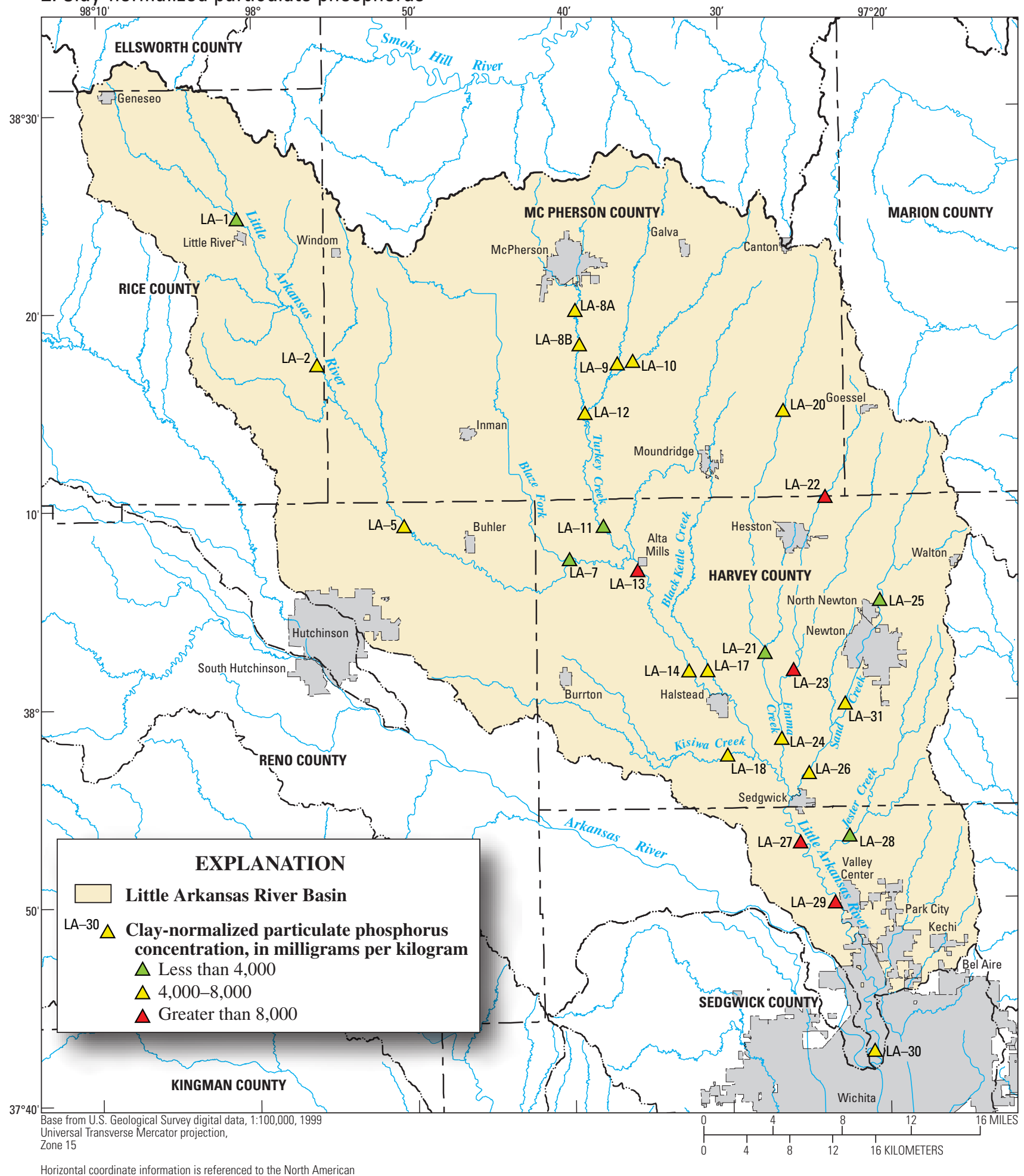

Horizontal coordinate information is referenced to the North American

Datum of 1983 (NAD 83)

Figure 4. Original, clay-normalized, and organic-carbon-normalized concentrations of particulate nitrogen and phosphorus in streambed-sediment samples collected in the Little Arkansas River Basin, south-central Kansas, January and March 2007.-Continued 
F. Organic-carbon-normalized particulate phosphorus

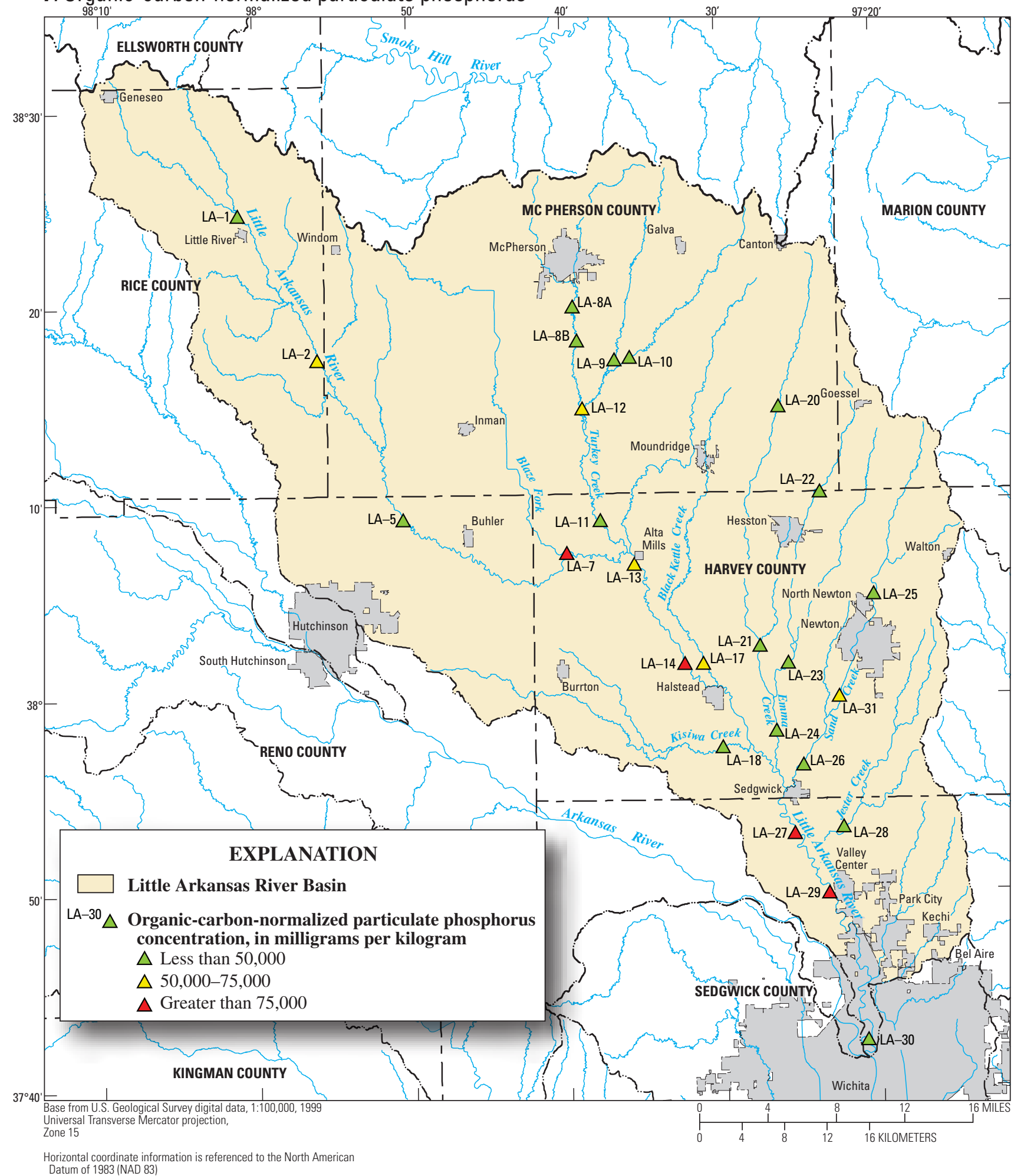

Figure 4. Original, clay-normalized, and organic-carbon-normalized concentrations of particulate nitrogen and phosphorus in streambed-sediment samples collected in the Little Arkansas River Basin, south-central Kansas, January and March 2007.-Continued 
To further account for differences in the particle-size composition of the sieved streambed-sediment samples, and thereby make the samples more directly comparable, a clay normalization was done in which the constituent concentrations were divided by the clay content for each sample. Clay content in the samples ranged from 10 percent (site LA-12) to 30 percent (sites LA-7, LA-18, LA-31) (table A2). The magnitudes of the particulate $\mathrm{N}$ and $\mathrm{P}$ concentrations were increased substantially as a result of the clay normalization (table A2); however, spatial patterns for the clay-normalized particulate $\mathrm{N}$ and $\mathrm{P}$ concentrations (fig. $4 B, E$ ) generally were consistent with the spatial patterns for the original concentrations (fig. $4 A, D$ ) with some variations evident. For example, along the main-stem Little Arkansas River, the average claynormalized particulate $\mathrm{N}$ and $\mathrm{P}$ concentrations upstream from Alta Mills (sites LA-1, LA-2, LA-5) remained low compared to the average concentrations at and downstream from Alta Mills (sites LA-13, LA-14, LA-27, LA-29, LA-30). However, increasing trends (in the downstream direction) for particulate $\mathrm{N}$ and $\mathrm{P}$ upstream from Alta Mills were more pronounced for the clay-normalized concentrations. The relation between the original and clay-normalized concentrations was statistically significant for both particulate N (Spearman's rho $=0.84$, twosided $\mathrm{p}$-value $=0.000)$ and particulate $\mathrm{P}($ Spearman's rho $=$ 0.82 , two-sided $\mathrm{p}$-value $=0.000)($ table A2).

A statistical comparison of the original and clay-normalized particulate $\mathrm{N}$ and $\mathrm{P}$ concentrations for the sampling sites with land use (that is, percentage of cropland, grassland, and urban; fig. 2) in the respective sampling-site subbasins indicated that none of the correlations were strong (for example, rho $>0.70$ ) and statistically significant (table 6). The absence of a strong correlation between nutrient concentrations in sediment and land use also was reported by Juracek (2004a) in a study of 10 small reservoirs in eastern Kansas. In a national study of the effects of land use on sediment chemistry, Horowitz and Stephens (2008) determined that agricultural land use (cropland and pasture) had little or no effect on downstream sediment concentrations of several constituents including phosphorus and carbon. Several factors may, in part, explain why rural land use alone is not an effective predictor of nutrient concentrations in sediment. For example, a general landuse classification provides little or no information on such important factors as land-management practices (for example, tillage practices, grazing intensity), fertilizer application, and livestock and poultry production.

Examination of the distribution of concentrated animal feeding operations (CAFOs) in the basin as of June 2007 (fig. 5), compared to the spatial variability in original particulate $\mathrm{N}$ and $\mathrm{P}$ concentrations in the streambed sediment (fig. $4 A, D$, table A2), indicated that livestock and poultry production might, in part, be responsible for some of the spatial differences in nutrient concentrations. For example, note that the streambed-sediment sampling sites with the largest particulate $\mathrm{N}$ concentrations (that is, sites LA-22 and LA-23 in the Emma Creek subbasin) are located in an area that has a relatively greater density of CAFOs. Likewise, along the main-stem Little Arkansas River, the increase in particulate $\mathrm{N}$ and $\mathrm{P}$ concentrations from site LA-2 to LA-5 may, in part, be caused by the multiple CAFOs located in the intervening drainage area (fig. 5). In addition to livestock and poultry production, the variability of nutrient concentrations may be caused by other factors for which information is not readily available. Such information includes background nutrient availability from the soils and bedrock in the subbasins, historical land-management practices, and historical fertilizer use.

The possible relation between original particulate $\mathrm{N}$ and $\mathrm{P}$ concentrations for the streambed-sediment sampling sites and livestock and poultry production in the sampling-site subbasins was investigated statistically. To enable the analysis, livestock and poultry production in each subbasin (as of June 2007) was standardized by dividing the number of animal units by the size of the subbasin. An animal unit is defined as a measurement used to make comparable the waste generated by different species of livestock and poultry (Robert Gavin, Kansas Department of Health and Environment, written commun., 2007). A statistically significant positive correlation (Spearman's rho $=0.44$, two-sided $p$-value $=0.025$ ) was indicated for the relation between particulate $\mathrm{N}$ concentrations in the streambed-sediment samples and the number of animal units per square mile in the subbasins; however, the correlation was not particularly strong. The relation between particulate $\mathrm{P}$ concentrations and animal units per square mile was not statistically significant (Spearman's rho $=0.23$, twosided $p$-value $=0.255$ ). Thus, whereas livestock and poultry production may be contributors of $\mathrm{N}$ and $\mathrm{P}$ to streambed sediments, they apparently are not the sole contributors, and their importance likely varies from site to site in the Little Arkansas River Basin. Factors that determine the importance of a CAFO as a source of $\mathrm{N}$ and $\mathrm{P}$ to a stream channel include proximity of the CAFO to the stream channel, number of animals, type of animal (amount of $\mathrm{N}$ and $\mathrm{P}$ in its waste), method of waste management employed (for example, land application), soil type, and topography. Non-CAFO livestock production also may be important as a nutrient source.

Effluent from wastewater-treatment facilities is a potential source of nutrients to streambed sediment. In the Little Arkansas River Basin, the ability to assess its importance as a source was limited by the locations of the streambed-sediment sites sampled. Within the basin, the two largest sources of effluent were the cities of McPherson and Newton, which each discharged about 2 million gallons per day in 2007 (Rance Walker, Kansas Department of Health and Environment, written commun., 2008). However, upstream and downstream sediment data were available only for Newton. Along Sand Creek, the original winter particulate $\mathrm{N}$ and $\mathrm{P}$ concentrations in the streambed sediment increased about 33 and 130 percent, respectively, from site LA-25 (upstream from Newton) to site LA-31 (downstream from Newton) (fig. $4 A, D$, table A2). The observed increases may be a result of effluent from the Newton wastewater-treatment facility located between the two streambed-sampling sites. Nutrients in effluent typically are dissolved and therefore bioavailable. The fates of dissolved 
Table 6. Results of correlation analyses for original and claynormalized particulate nitrogen and phosphorus concentrations for streambed-sediment sampling sites as compared to land use in the sampling-site subbasins.

$\left[\mathrm{TN}_{\mathrm{o}}\right.$, original particulate nitrogen concentration; $\mathrm{TN}_{\mathrm{c}}$, clay-normalized particulate nitrogen concentration; $\mathrm{TP}_{\mathrm{o}}$, original particulate phosphorus concentration; $\mathrm{TP}_{\mathfrak{c}}$, clay-normalized particulate phosphorus concentration; $\%$, percentage of subbasin]

\begin{tabular}{lcl}
\hline Variables compared & $\begin{array}{c}\text { Spearman's } \\
\text { rho }\end{array}$ & $\begin{array}{c}\text { Correlation test at 0.10 level } \\
\text { of significance } \\
\text { (two-sided p-value) }\end{array}$ \\
\hline $\mathrm{TN}_{\mathrm{o}}$ and cropland \% & -0.35 & negative correlation $(0.076)$ \\
$\mathrm{TN}_{\mathrm{o}}$ and grassland \% & .37 & positive correlation $(0.060)$ \\
$\mathrm{TN}_{\mathrm{o}}$ and urban \% & .17 & no correlation $(0.401)$ \\
$\mathrm{TN}_{\mathrm{c}}$ and cropland \% & -.24 & no correlation $(0.235)$ \\
$\mathrm{TN}_{\mathrm{c}}$ and grassland \% & .19 & no correlation $(0.345)$ \\
$\mathrm{TN}_{\mathrm{c}}$ and urban \% & .15 & no correlation $(0.468)$ \\
$\mathrm{TP}_{\mathrm{o}}$ and cropland \% & -.38 & negative correlation $(0.058)$ \\
$\mathrm{TP}_{\mathrm{o}}$ and grassland \% & .33 & no correlation $(0.105)$ \\
$\mathrm{TP}_{\mathrm{o}}$ and urban \% & .27 & no correlation $(0.177)$ \\
$\mathrm{TP}_{\mathrm{c}}$ and cropland \% & -.28 & no correlation $(0.161)$ \\
$\mathrm{TP}_{\mathrm{c}}$ and grassland \% & .19 & no correlation $(0.360)$ \\
$\mathrm{TP}_{\mathrm{c}}$ and urban \% & .28 & no correlation $(0.167)$ \\
\hline
\end{tabular}

nutrients in a stream include downstream transport, transformation, uptake by plants and algae, and accumulation in streambed sediment (Allan, 1995).

The site-to-site variability in original particulate OC concentrations (fig. 6, table A2) for the winter samples paralleled the spatial patterns observed for the original particulate $\mathrm{N}$ and $\mathrm{P}$ concentrations (fig. 4A,D, table A2) and the correlations between particulate $\mathrm{OC}$ and particulate $\mathrm{N}$ and $\mathrm{P}$ were statistically significant (two-sided p-value $=0.000$ ). The Spearman's rho correlation coefficients for the relation between particulate $\mathrm{OC}$ and $\mathrm{N}$ and between particulate $\mathrm{OC}$ and $\mathrm{P}$ were 0.96 and 0.83 , respectively (fig. 7). Particulate OC content in the samples ranged from 0.7 percent (site LA-7) to 5.8 percent (site LA-23) (table A2). The relation between particulate OC and clay content was not statistically significant (Spearman's rho $=0.29$, two-sided $p$-value $=0.154$ ) for the winter samples.

Temporal variability in original nutrient concentrations was assessed by a comparison of the winter and summer sediment samples. With the exception of site LA-11 (for which particulate $\mathrm{N}$ and $\mathrm{P}$ concentrations in the summer sample were substantially larger), particulate $\mathrm{N}$ and $\mathrm{P}$ concentrations in the summer samples were substantially smaller with respective mean decreases of 63 and 51 percent (fig. 8). Among the eight sites that were resampled, the largest particulate $\mathrm{N}$ concentrations for both time periods were measured for site LA-23 (fig. 8, tables A2, A3). The change in nutrient concentrations does not appear to be clearly related to the percentage of clay in the samples as the decreases occurred regardless of whether the clay content increased or decreased. For example, similar decreases in particulate $\mathrm{N}$ and $\mathrm{P}$ concentrations were determined for sites LA-27 and LA-29 despite the fact that clay content in the summer sample was 100 percent larger for the former and 48 percent smaller for the latter (tables A2, A3).

However, the change in original nutrient concentrations does appear to be related to particulate OC content in the samples. For site LA-11, a modest increase in particulate OC content for the summer sample was accompanied by substantial increases in particulate $\mathrm{N}$ and $\mathrm{P}$ relative to the winter sample. Conversely, large decreases in particulate OC content for the remaining summer samples were accompanied by substantial decreases in particulate $\mathrm{N}$ and $\mathrm{P}$ (tables A2, A3). Thus, given that OC provides an approximate determination of total organic material in a sediment sample (Horowitz, 1991), a likely explanation is that particulate $\mathrm{N}$ and $\mathrm{P}$ preferentially sorb to organic matter in the sediment (Neal and others, 1997). Another possible explanation is a change in particle size. For example, an increase in particle size (that is, more silt) could account, in part, for decreases in N, P, and OC content.

Several possible explanations may account, in part, for the typically lower particulate OC concentrations (and associated particulate $\mathrm{N}$ and $\mathrm{P}$ concentrations) in the summer samples. One possible contributing factor is a change in particle size as previously discussed. A second possibility is the series of high flows that occurred between the last winter sampling date (March 2007) and the summer sampling date (August 2007) (fig. 3). The high flows may have flushed out organic matter that had accumulated on the streambeds during the preceding prolonged period of low flows. Also, the high flows may have delivered an increased load of sediment derived from channel-bank sources that typically are low in OC content (and N and P content) compared to surface soils (Walling and Woodward, 1995; Jobbagy and Jackson, 2000; Juracek, 2004b; Juracek and Ziegler, 2007). Another possibility is that the lower OC content in the summer samples was caused, in part, by warmer waters which typically have higher decomposition rates of organic matter (Smol, 2002).

Given the apparent relation between particulate $\mathrm{N}$ and $\mathrm{P}$ and particulate OC (fig. 7), it was decided to normalize the original nutrient concentrations in the winter samples by dividing by the particulate OC content. The magnitudes of the particulate $\mathrm{N}$ and $\mathrm{P}$ concentrations were increased as a result of the OC normalization. A statistically significant correlation was determined for the relation between the original and OC-normalized particulate N concentrations (Spearman's rho $=0.82$, two-sided $\mathrm{p}$ value $=0.000)$ and the spatial patterns generally were consistent (figs. $4 A, C$, table A2). For example, along the main-stem Little Arkansas River, the average OCnormalized particulate $\mathrm{N}$ concentration upstream from Alta Mills (sites LA-1, LA-2, LA-5) remained low compared to the average concentration at and downstream from Alta Mills (sites LA-13, LA-14, LA-27, LA-29, LA-30). 


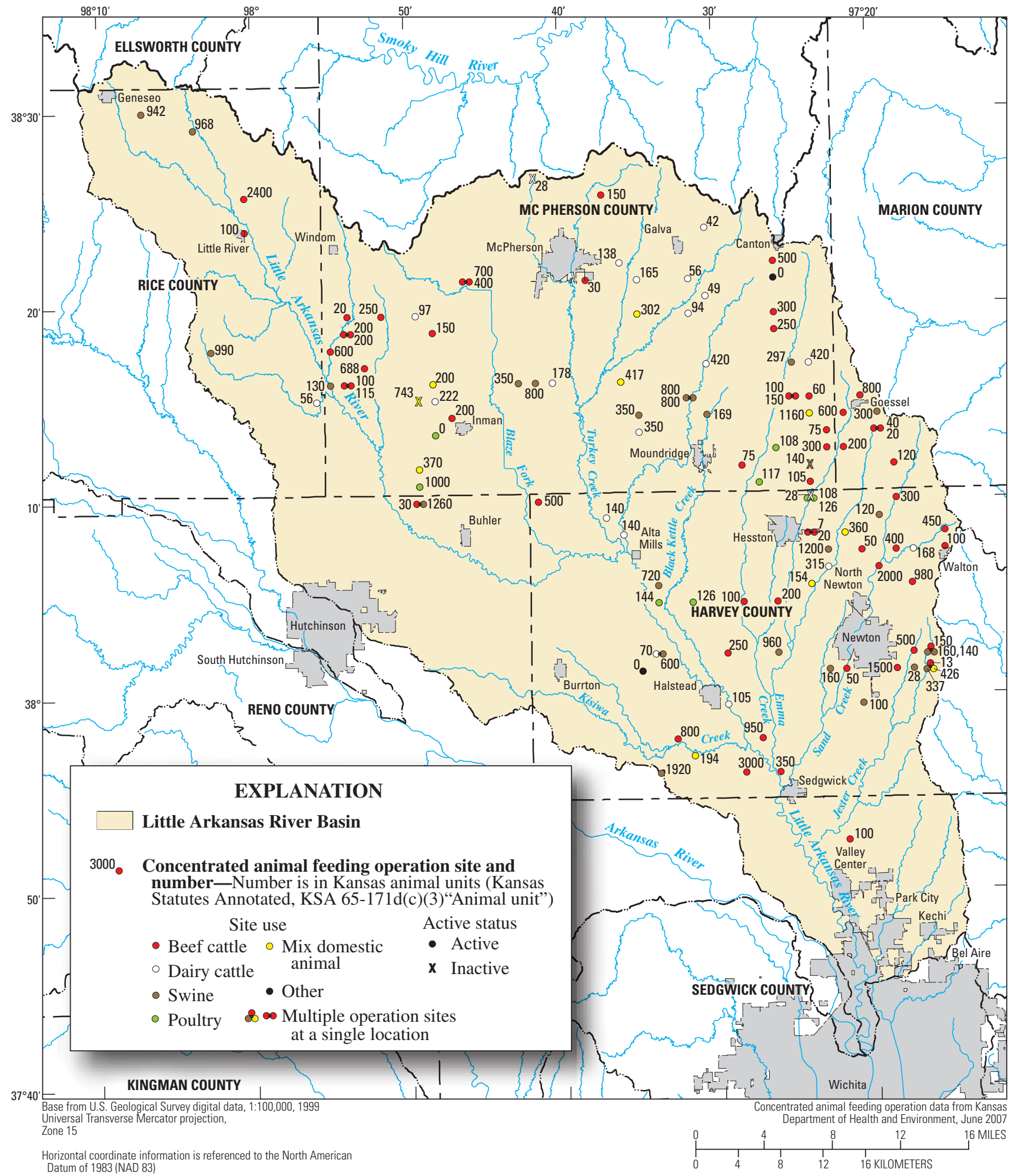

Figure 5. Concentrated animal feeding operations (CAFOs) in the Little Arkansas River Basin, south-central Kansas, June 2007. 
A. Particulate organic carbon

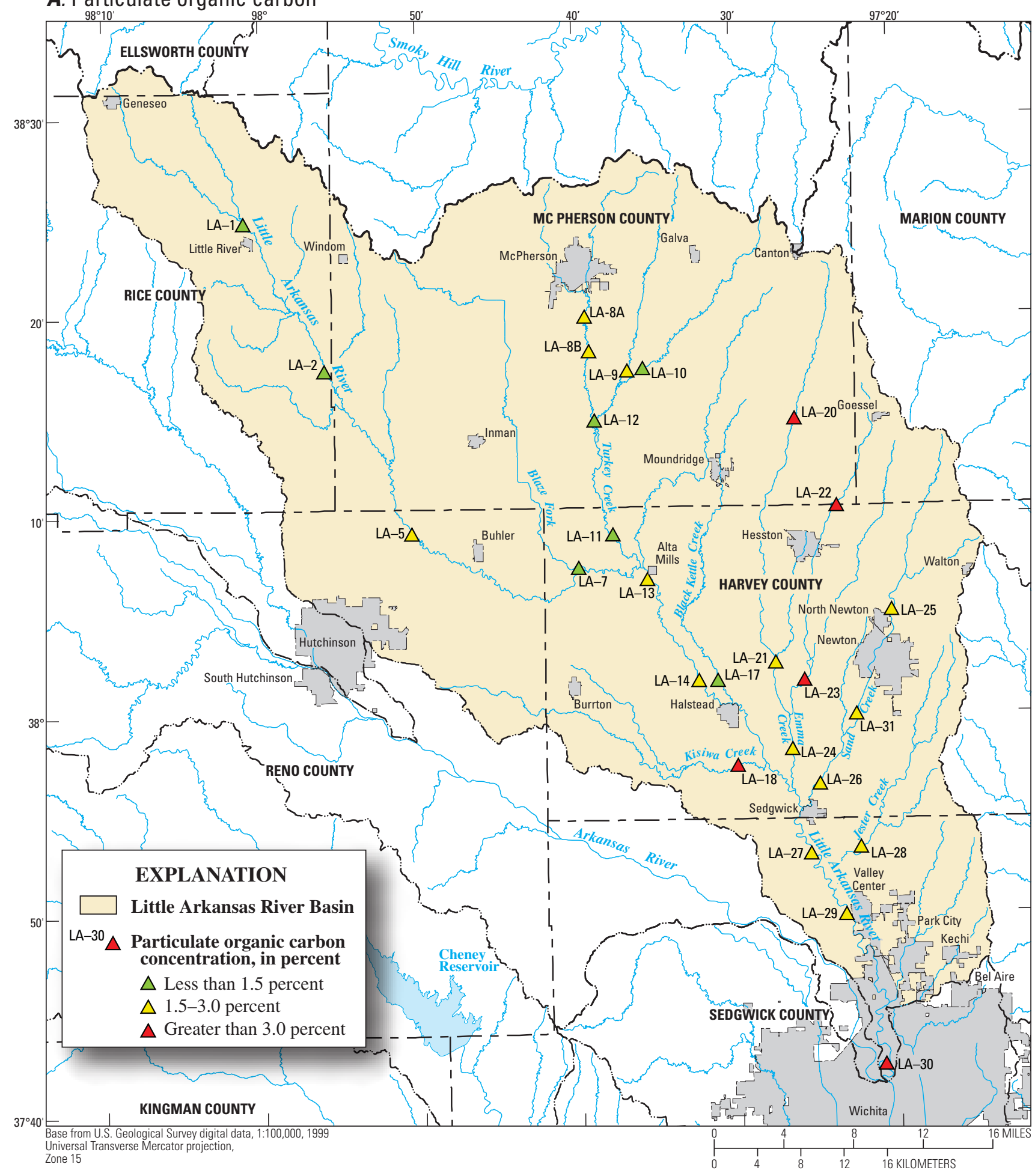

Horizontal coordinate information is referenced to the North American Datum of 1983 (NAD 83)

Figure 6. Original $(A)$ and clay-normalized $(B)$ concentrations of particulate organic carbon in streambed-sediment samples collected in the Little Arkansas River Basin, south-central Kansas, January and March 2007. 
B. Clay-normalized particulate organic carbon

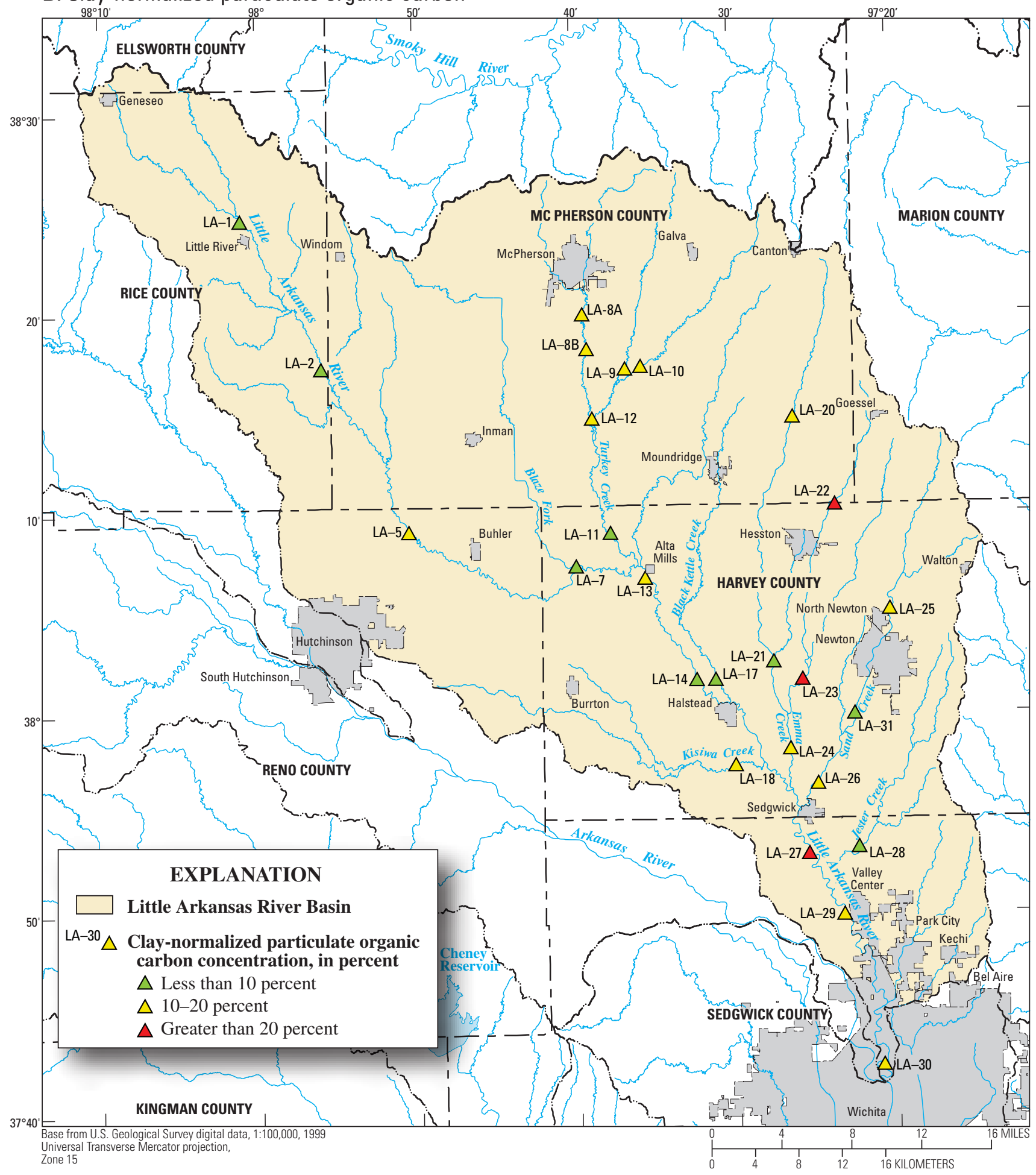

Horizontal coordinate information is referenced to the North American Datum of 1983 (NAD 83)

Figure 6. Original $(A)$ and clay-normalized $(B)$ concentrations of particulate organic carbon in streambed-sediment samples collected in the Little Arkansas River Basin, south-central Kansas, January and March 2007.-Continued 

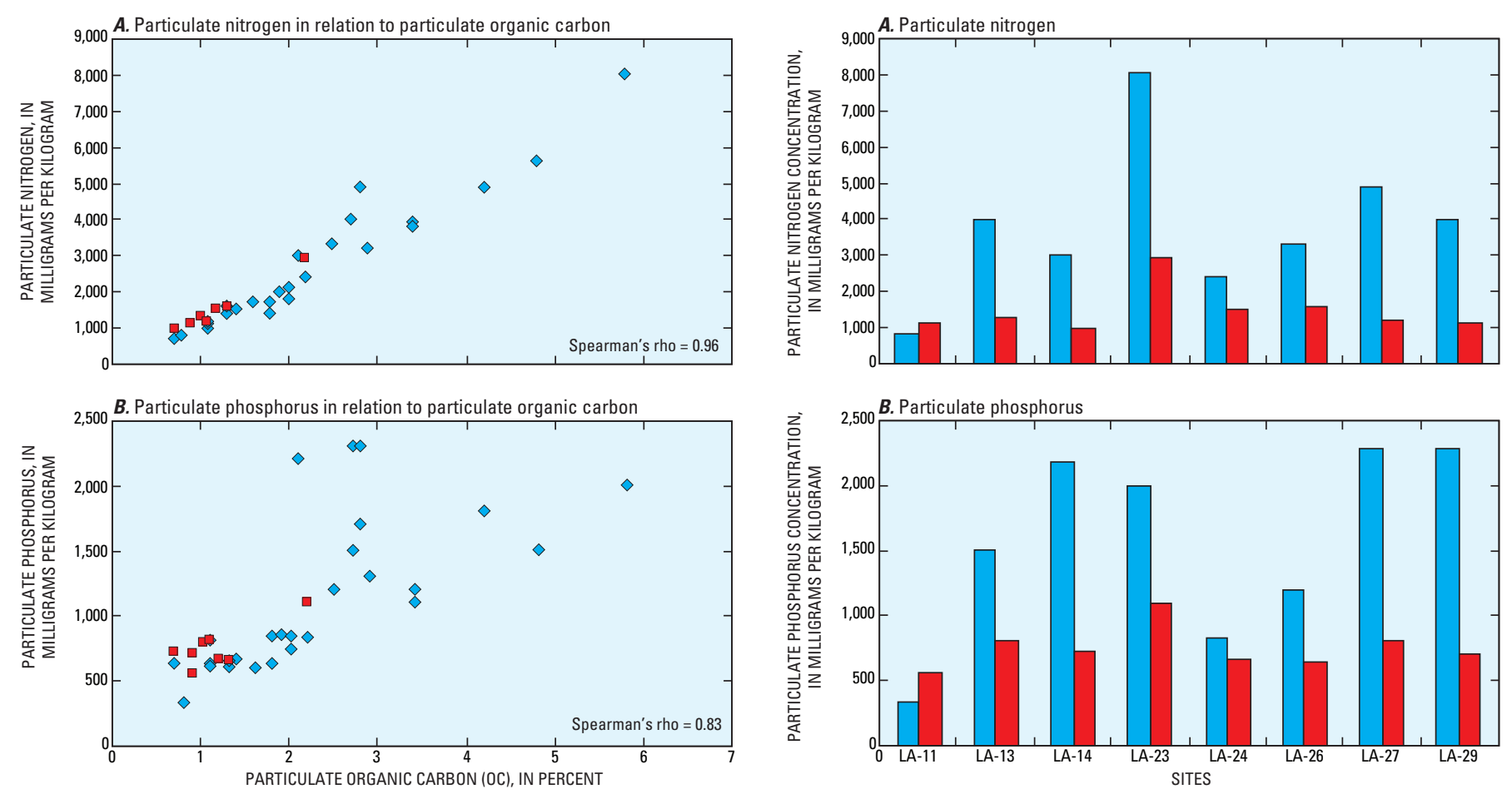

EXPLANATION

Streambed-sediment sample

$\diamond$ Winter sample collected January or March 2007

- Summer sample collected August 2007

Figure 7. Variation in particulate nitrogen $(A)$ and phosphorus $(B)$ concentrations in relation to particulate organic carbon concentrations for streambed-sediment samples collected in the Little Arkansas River Basin, south-central Kansas, January, March, and August 2007.

In contrast, the relation between the original and OCnormalized particulate $\mathrm{P}$ concentrations for the winter samples was not statistically significant (Spearman's rho $=0.16$, twosided $\mathrm{p}$ value $=0.433)$ (figs. $4 D, F$, table A2). Nevertheless, with one exception, the main-stem pattern of lower concentrations upstream from Alta Mills was evident. The exception was site LA-30 (Little Arkansas River at Wichita, Kansas) for which the OC-normalized particulate $\mathrm{P}$ concentration was similar to or less than the concentrations for the sites upstream from Alta Mills.

\section{Trace Elements}

Site-to-site variability in particulate trace element concentrations was substantial for the winter samples, though typically less than for the nutrients. Exceptions were manganese and selenium for which order-of-magnitude differences were measured (tables 5, A2).

Urban sources of contamination (for example, industry, vehicular traffic, wastewater-treatment facilities) likely

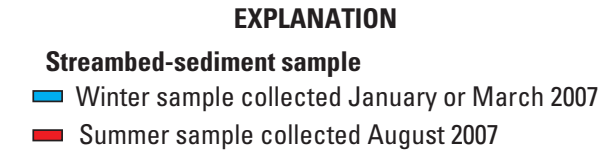

Figure 8. Variation in particulate nitrogen $(A)$ and phosphorus $(B)$ concentrations for streambed-sediment samples collected in the Little Arkansas River Basin, south-central Kansas, January, March, and August 2007.

accounted for relatively large trace element concentrations at some sites. For example, downstream from the city of McPherson, Kansas, along Turkey Creek, relatively large concentrations of copper, lead, and zinc were measured at sites LA-8A and LA-8B. The largest concentrations of copper $(60 \mathrm{mg} / \mathrm{kg})$, lead $(51 \mathrm{mg} / \mathrm{kg})$, silver $(0.9 \mathrm{mg} / \mathrm{kg})$, and zinc $(180 \mathrm{mg} / \mathrm{kg})$ were measured at site LA-31, which is located along Sand Creek downstream from the city of Newton, Kansas (fig. 2, table A2). In a national study of the effects of land use on sediment chemistry, Horowitz and Stephens (2008) determined that urban land use typically caused substantial increases in the downstream sediment concentrations of several trace elements including cadmium, copper, lead, mercury, silver, and zinc.

Sediment quality was assessed with respect to the eight trace elements for which SQGs were available (table 3). For the 26 streambed sites sampled, sediment concentrations of the eight trace elements generally were less than the threshold-effects guidelines; that is, for each trace element, 15 percent or less of the winter samples had concentrations that exceeded the threshold-effects guideline (table A2). None of the samples had concentrations that exceeded the probable- 
effects guidelines. Sampling sites for which two or more trace element concentrations exceeded the threshold-effects guidelines were LA-5 (chromium, nickel), LA-8B (chromium, lead, zinc), LA-18 (chromium, zinc), LA-23 (nickel, zinc), and LA-31 (copper, lead, silver, zinc) (fig. 2, table A2).

Temporal variability, assessed by a comparison of the winter and summer samples for eight sites, indicated that trace element concentrations for the summer samples typically were either similar to or smaller than concentrations for the winter samples (tables A2, A3). This pattern was evident despite the fact that the percentage of clay in the summer samples ranged from 100 percent more to 48 percent less than the winter samples. Thus, a consistent relation between trace element concentrations and percentage of clay was not observed. As with the nutrients, trace element concentrations appeared to be more closely related to changes in particulate OC content, which decreased substantially for all resampled sites with the exception of site LA-11 (tables A2, A3). The relation between copper and zinc concentrations and particulate OC concentrations for all samples is shown in figure 9.
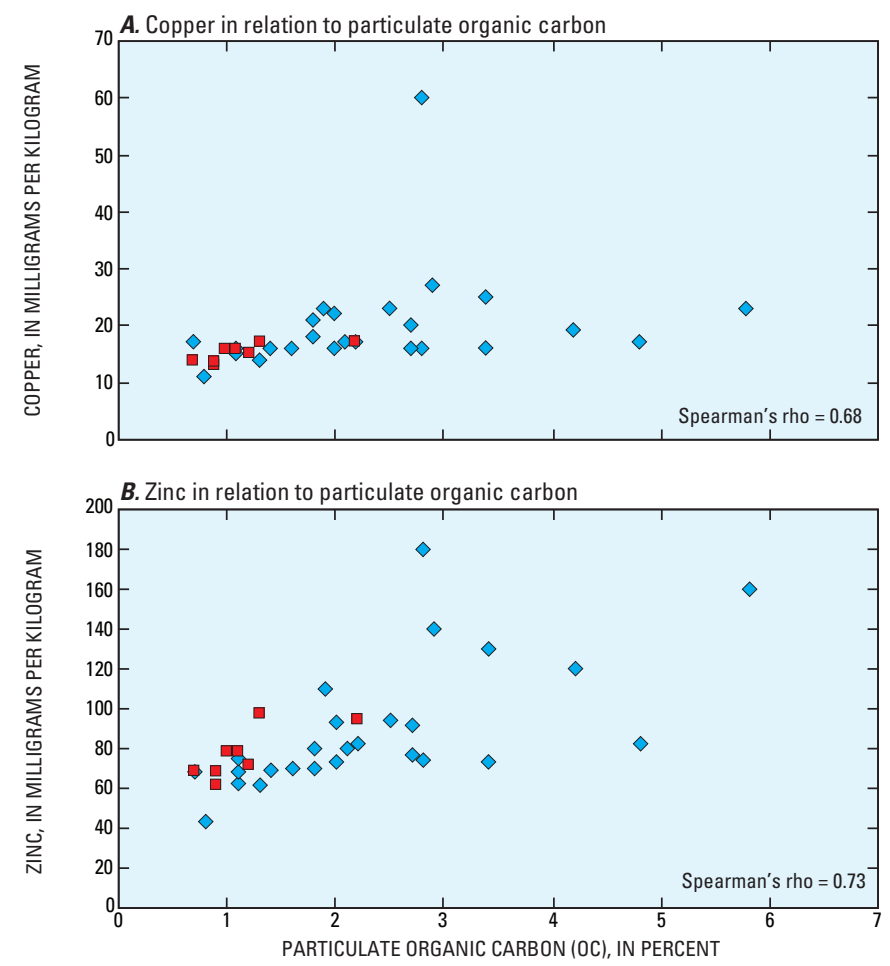

EXPLANATION

Streambed-sediment sample

$\diamond$ Winter sample collected January or March 2007

- Summer sample collected August 2007

Figure 9. Variation in copper $(A)$ and zinc $(B)$ concentrations in relation to particulate organic carbon concentrations for streambed-sediment samples collected in the Little Arkansas River Basin, south-central Kansas, January, March, and August 2007.

\section{Radionuclides}

The radionuclides ${ }^{7} \mathrm{Be},{ }^{137} \mathrm{Cs},{ }^{210} \mathrm{~Pb}$, and ${ }^{226} \mathrm{Ra}$ were analyzed to investigate variability throughout the basin and assess the potential for use in a sediment-source study. Overall, substantial site-to-site variability was indicated for ${ }^{7} \mathrm{Be},{ }^{137} \mathrm{Cs}$, and ${ }^{210} \mathrm{~Pb}$ (tables 5, A2). Site-to-site variability in original and clay-normalized ${ }^{137} \mathrm{Cs}$ is shown in figure 10 . The variability may be indicative of differences in the relative importance of sediment sources (for example, channel banks and surface soils) among the sampling sites. Potentially, radionuclides (perhaps in combination with other constituents) could be used to determine sediment sources in the basin. Such a study would involve a comparison of the composition of streambed or suspended sediments with potential sediment sources to determine the relative importance of the sources throughout the basin. Recently, Juracek and Ziegler (2007) used ${ }^{137} \mathrm{Cs}$ and other constituents to estimate sediment sources in the Perry Lake and Lake Wabaunsee Basins of northeast Kansas.

Temporally, a comparison of the winter and summer samples for the eight resampled sites indicated that ${ }^{137} \mathrm{Cs}$ activity was characterized by minimal or inconsistent variability with respect to substantial changes in clay percentage and particulate OC content. Conversely, ${ }^{7} \mathrm{Be}$ and ${ }^{210} \mathrm{~Pb}$ activities in the summer samples typically were substantially smaller than in the winter samples (tables A2, A3). Thus, ${ }^{7} \mathrm{Be}$ and ${ }^{210} \mathrm{~Pb}$ activities appear to be more directly related to particulate OC content, which was substantially smaller in the summer samples with the exception of site LA- 11 . The relation between ${ }^{7} \mathrm{Be}$, ${ }^{137} \mathrm{Cs}$, and ${ }^{210} \mathrm{~Pb}$ activities and particulate $\mathrm{OC}$ concentrations for all samples is shown in figure 11.

\section{Bacteria}

Enterococci, E. coli, and fecal coliform are the three most common indicator bacteria used to provide a measure of the pathogenicity of surface water. Currently (2008), there are no USEPA guidelines or typical background densities published for these bacteria in freshwater streambed sediment.

Bacteria densities in the streambed sediment were variable. Respectively, the density ranges for enterococci, E. coli, and fecal coliform were 160 to greater than $6,500 \mathrm{col} / \mathrm{g}_{\mathrm{DW}}$ (colonies per gram, dry weight), 45 to $320 \mathrm{col} / \mathrm{g}_{\mathrm{DW}}$, and 150 to $680 \mathrm{col} / \mathrm{g}_{\text {DW }}$ (table 7). The largest densities of E. coli and fecal coliform bacteria were determined for sites LA-8A (Turkey Creek south of McPherson, Kansas), LA-11 (Turkey Creek near Buhler, Kansas), and LA-13 (Little Arkansas River at Alta Mills, Kansas) (fig. 2). In comparison, the density ranges for enterococci, E. coli, and fecal coliform in streambed-sediment samples collected in Johnson County, Kansas, in 2003 were 11 to $9,100 \mathrm{col} / \mathrm{g}_{\mathrm{DW}}$, less than 11 to $850 \mathrm{col} / \mathrm{g}_{\mathrm{DW}}$, and less than 10 to $820 \mathrm{col} / \mathrm{g}_{\mathrm{DW}}$ respectively (Lee and others, 2005). 
A. Cesium-137

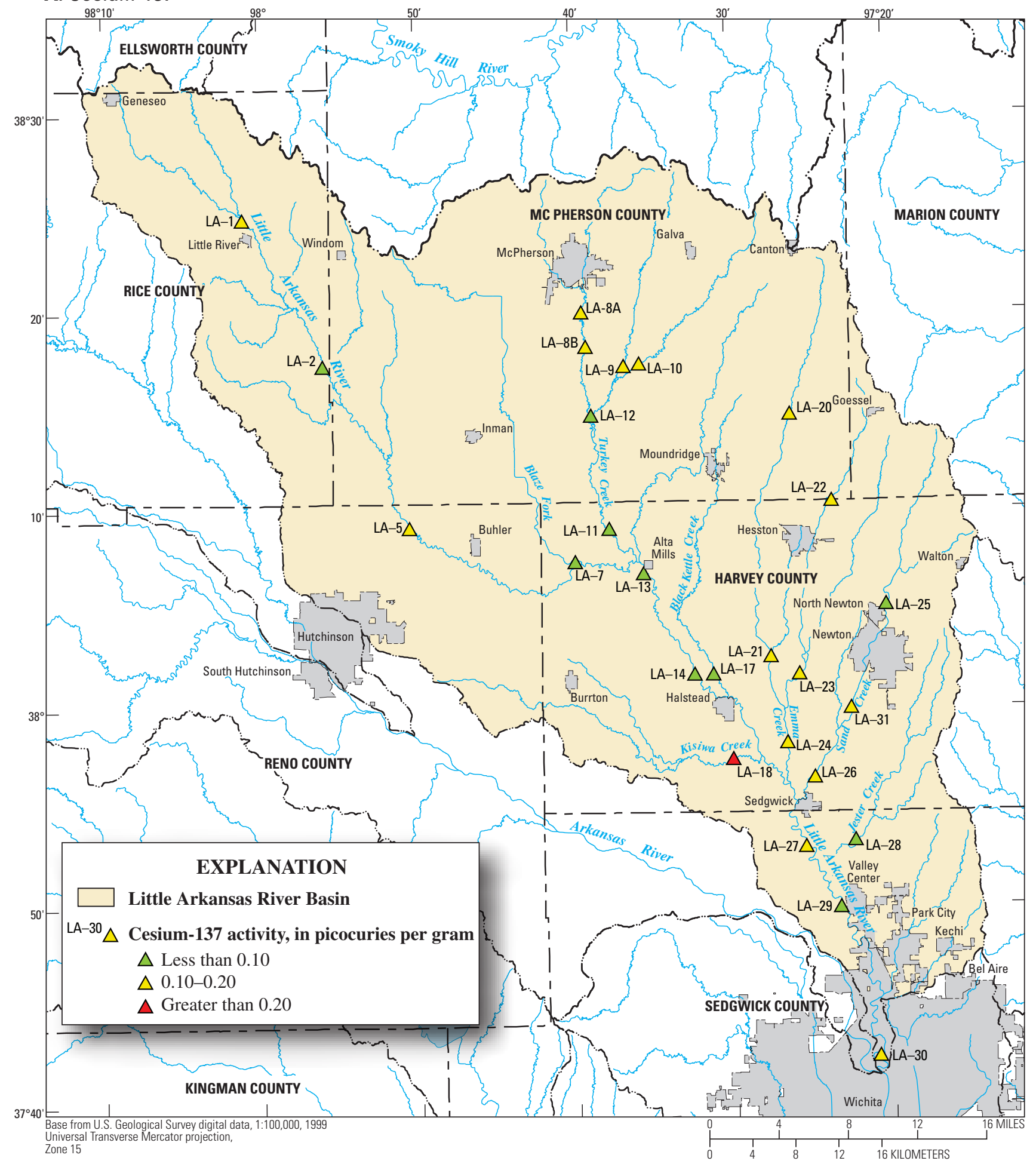

Horizontal coordinate information is referenced to the North American Datum of 1983 (NAD 83)

Figure 10. Original $(A)$ and clay-normalized $(B)$ cesium-137 activity in streambed-sediment samples collected in the Little Arkansas River Basin, south-central Kansas, January and March 2007. 
B. Clay-normalized cesium-137

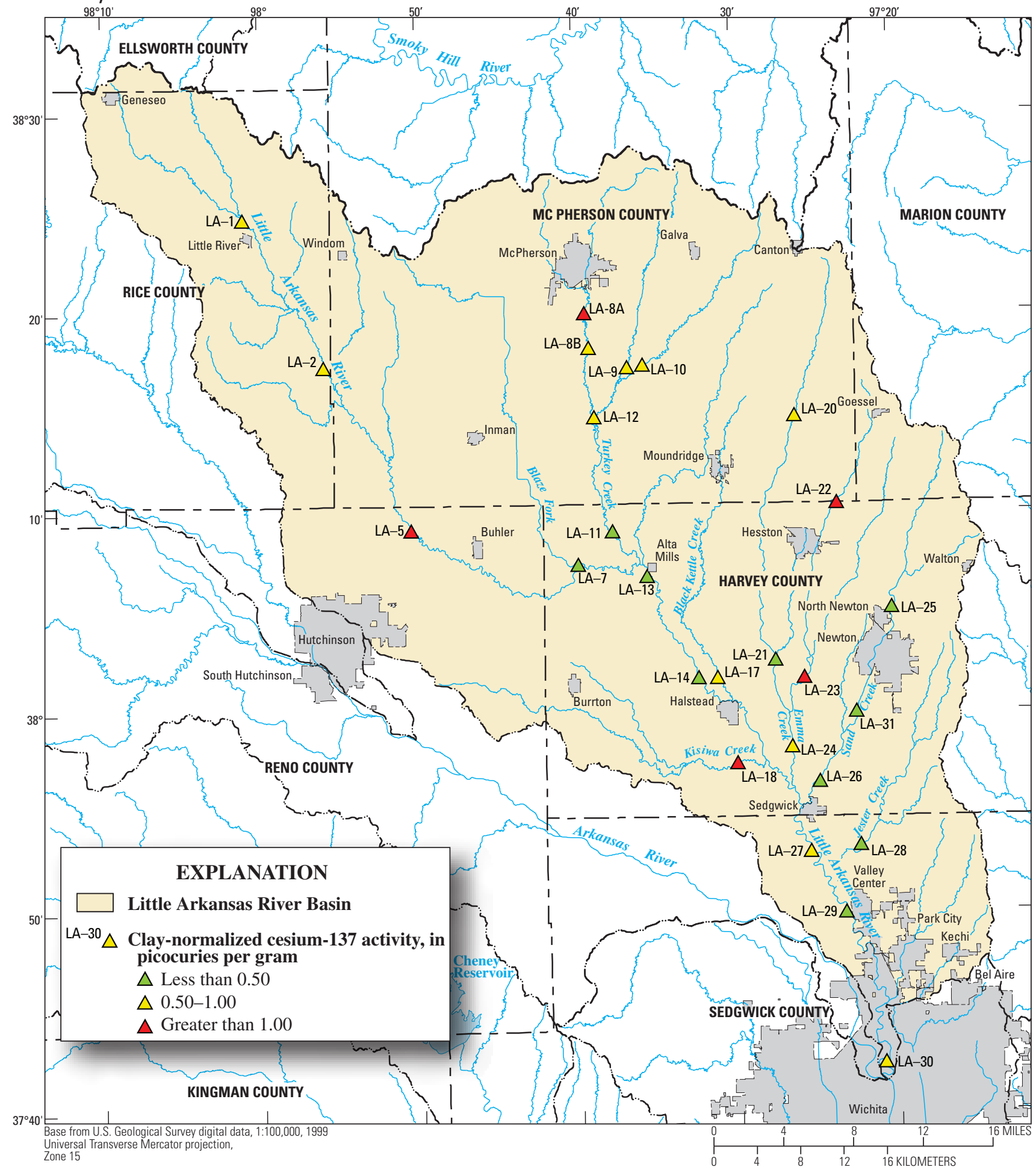

Horizontal coordinate information is referenced to the North American

Figure 10. Original $(A)$ and clay-normalized $(B)$ cesium-137 activity in streambed-sediment samples collected in the Little Arkansas River Basin, south-central Kansas, January and March 2007.-Continued 

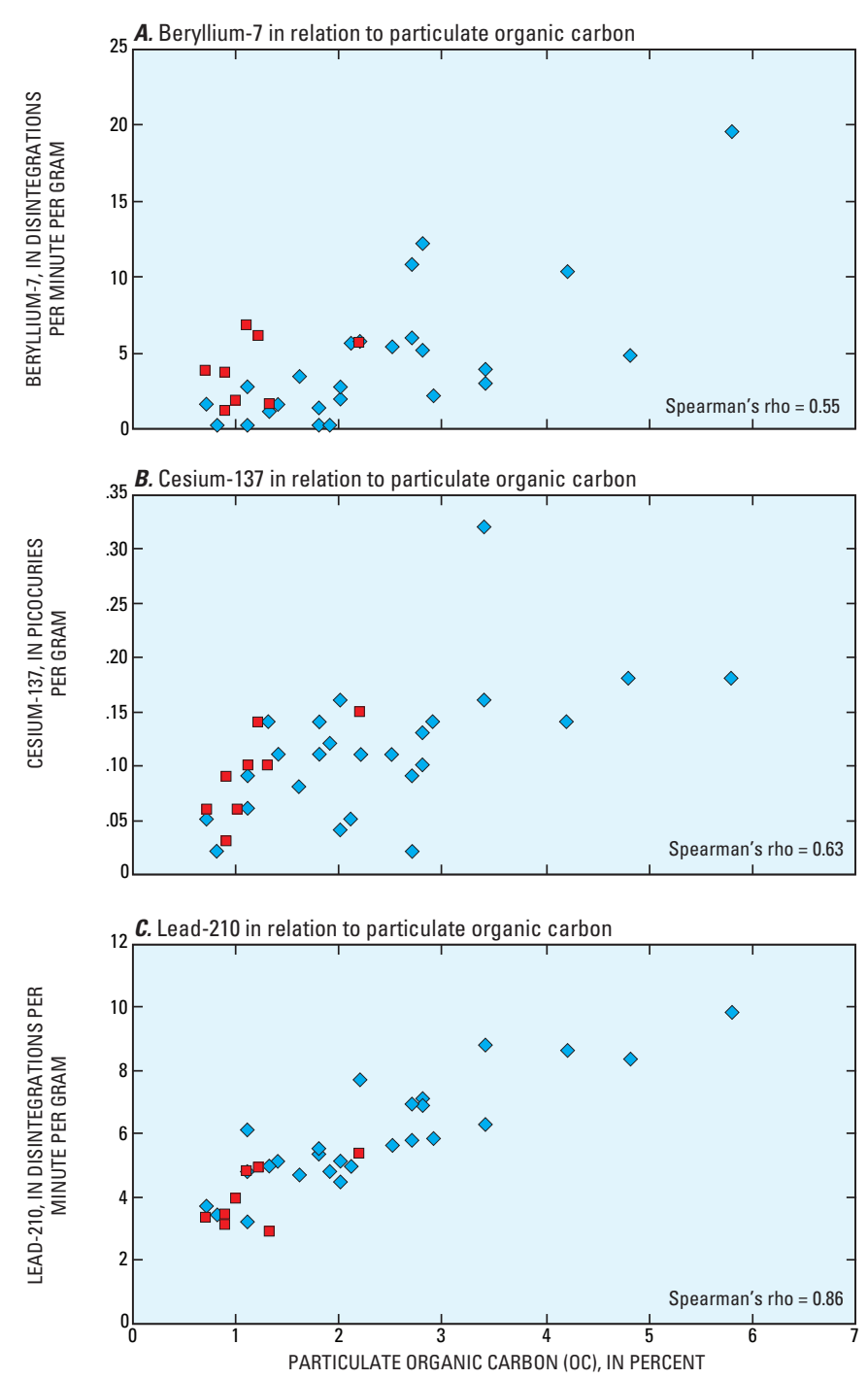

EXPLANATION

Streambed-sediment sample

$\diamond$ Winter sample collected January or March 2007

- Summer sample collected August 2007

Figure 11. Variation in beryllium-7 (A), cesium-137 (B), and lead-210 (C) activities in relation to particulate organic carbon concentrations for streambed-sediment samples collected in the Little Arkansas River Basin, south-central Kansas, January, March, and August 2007.

\section{Comparison of Historical Water Quality to Streamflow and Sediment Quality}

Historical water quality was compared with streamflow and streambed-sediment quality for eight selected sites in the Little Arkansas River Basin. In general, particulate N, P, and OC content in the water samples decreased as streamflow increased. Restated, as flow increased, the TSS concentration in the water samples increased at a faster rate than did the content of particulate N, P, and OC in the TSS. The relation between particulate N, P, and OC content in the water samples and streamflow was less certain for sites LA-11 (Turkey Creek near Buhler, Kansas), LA-24 (Emma Creek near Sedgwick, Kansas), and LA-26 (Sand Creek near Sedgwick, Kansas) because of a lack of samples collected during high-flow conditions (figs. 12, 13, 14).

Previous studies indicated that the relation between nutrient content in the water and streamflow may be location specific. For example, reported relations between P content and streamflow have been both direct (Vaithiyanathan and Correll, 1992; Vanni and others, 2001) and inverse (Preston and others, 1989). Rosensteel and Strom (1991) reported that $\mathrm{P}$ content was directly related to flow during storm conditions but inversely related to flow during non-storm conditions. Most $\mathrm{P}$ transported in streamflow is in the particulate phase (Holtan and others, 1988; Vanni and others, 2001; Pierzynski and others, 2005).

The particulate N, P, and OC content in the streambedsediment samples also indicated a relation with streamflow. That is, with the exception of site LA-11 (Turkey Creek near Buhler, Kansas), the winter samples plotted higher than the summer samples (figs. 12, 13, 14). The winter samples were collected during an extended period of low streamflow with minimal variability, whereas the summer samples were collected following a period that included several high flows (fig. 3). For site LA-11, the summer sample plotted higher for particulate $\mathrm{N}$ and $\mathrm{P}$. A summer sample was not collected for site LA-30 (Little Arkansas River at Wichita, Kansas).

Table 7. Densities of total coliform, Escherichia coli, fecal coliform, and enterococci for streambed-sediment samples collected from the Little Arkansas River Basin, south-central Kansas, September 2007.

$[>$, greater than; E, estimated]

\begin{tabular}{llccc}
\hline $\begin{array}{c}\text { Sampling } \\
\text { site number } \\
\text { (fig. 2) }\end{array}$ & $\begin{array}{c}\text { Total } \\
\text { coliform, } \\
\text { colonies } \\
\text { per gram }\end{array}$ & $\begin{array}{c}\text { Escheri- } \\
\text { chia coli, } \\
\text { colonies } \\
\text { per gram }\end{array}$ & $\begin{array}{c}\text { Fecal } \\
\text { coliform, } \\
\text { colonies } \\
\text { per gram }\end{array}$ & $\begin{array}{c}\text { Entero- } \\
\text { cocci, } \\
\text { colonies } \\
\text { per gram }\end{array}$ \\
\hline LA-8A & $>3,200$ & 260 & E 330 & $>320$ \\
LA-11 & $>4,400$ & 280 & 410 & $>4,400$ \\
LA-13 & $>4,400$ & E 320 & 320 & $>4,400$ \\
LA-13- & $>4,100$ & 260 & E 680 & $>4,100$ \\
replicate & & & & \\
LA-14 & $>4,200$ & 45 & E 170 & $>4,200$ \\
& & & & \\
LA-24 & $>3,000$ & 130 & 150 & $>300$ \\
LA-24- & $>3,100$ & 220 & 280 & E 160 \\
replicate & & & & $>410$ \\
LA-26 & $>4,100$ & 160 & E 240 & $>5,300$ \\
LA-27 & $>5,300$ & 120 & 150 & $>6,500$ \\
LA-29 & $>6,500$ & 73 & E 220 & \\
\hline
\end{tabular}



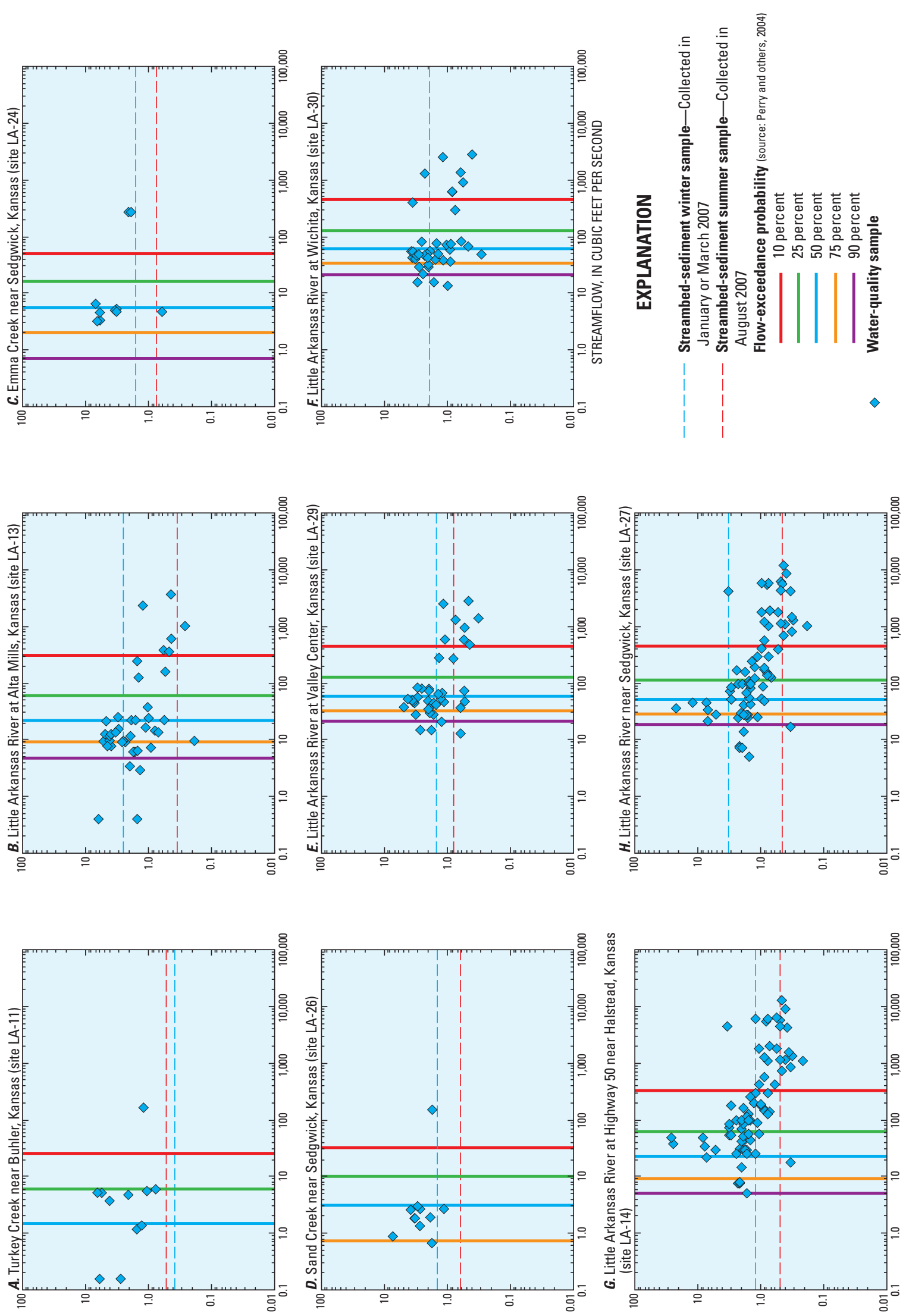

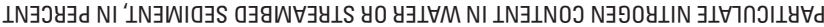

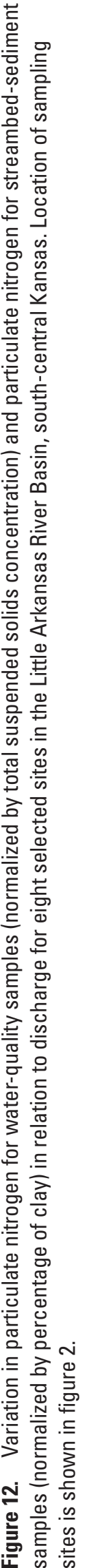



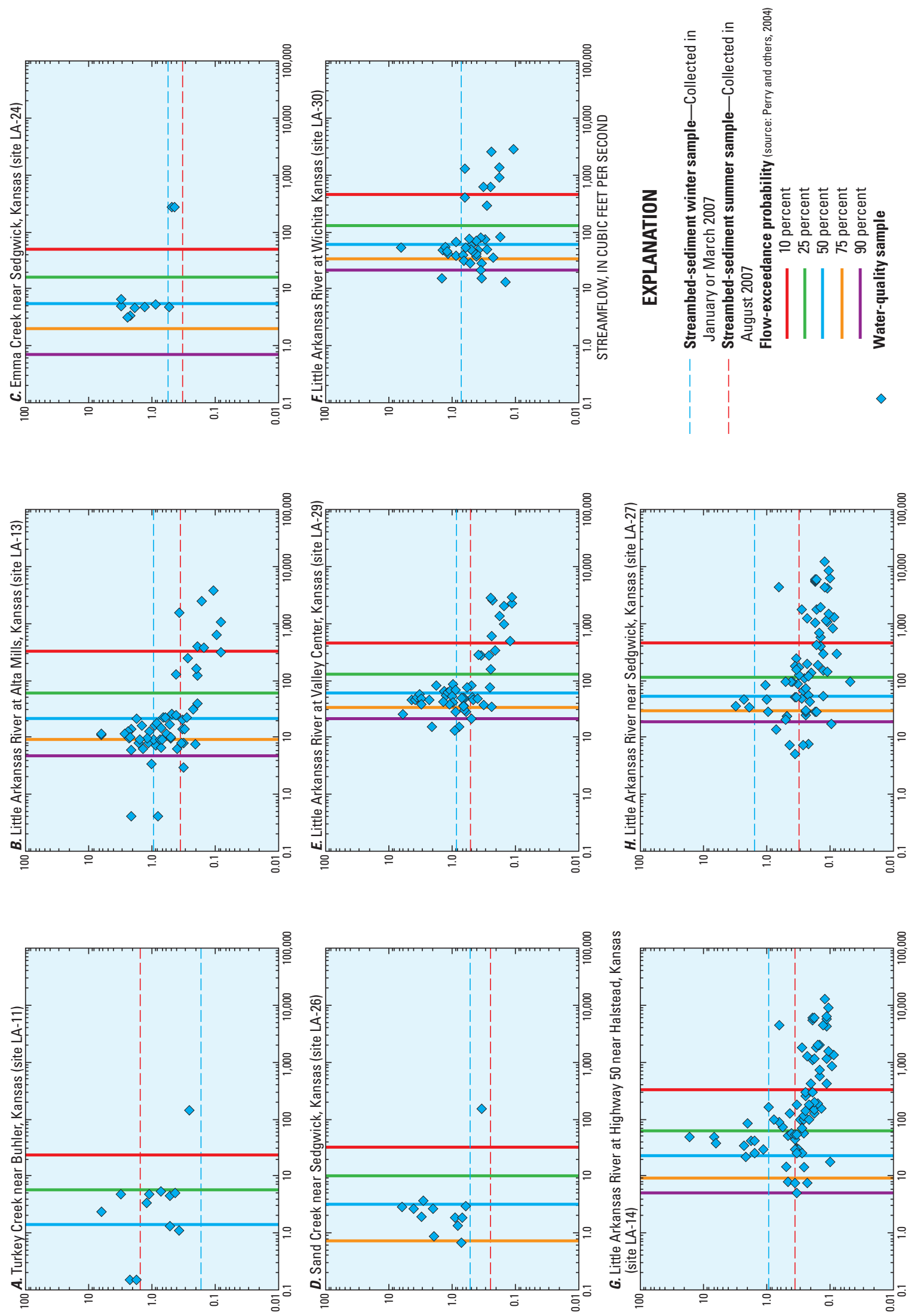

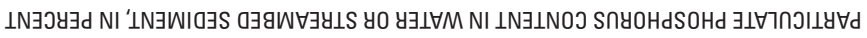

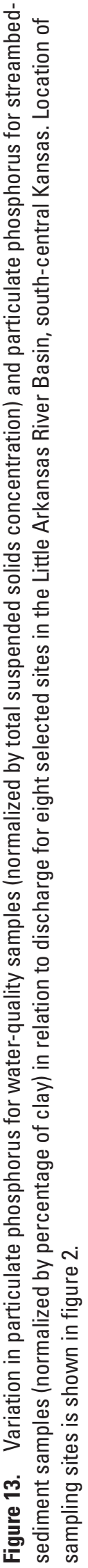



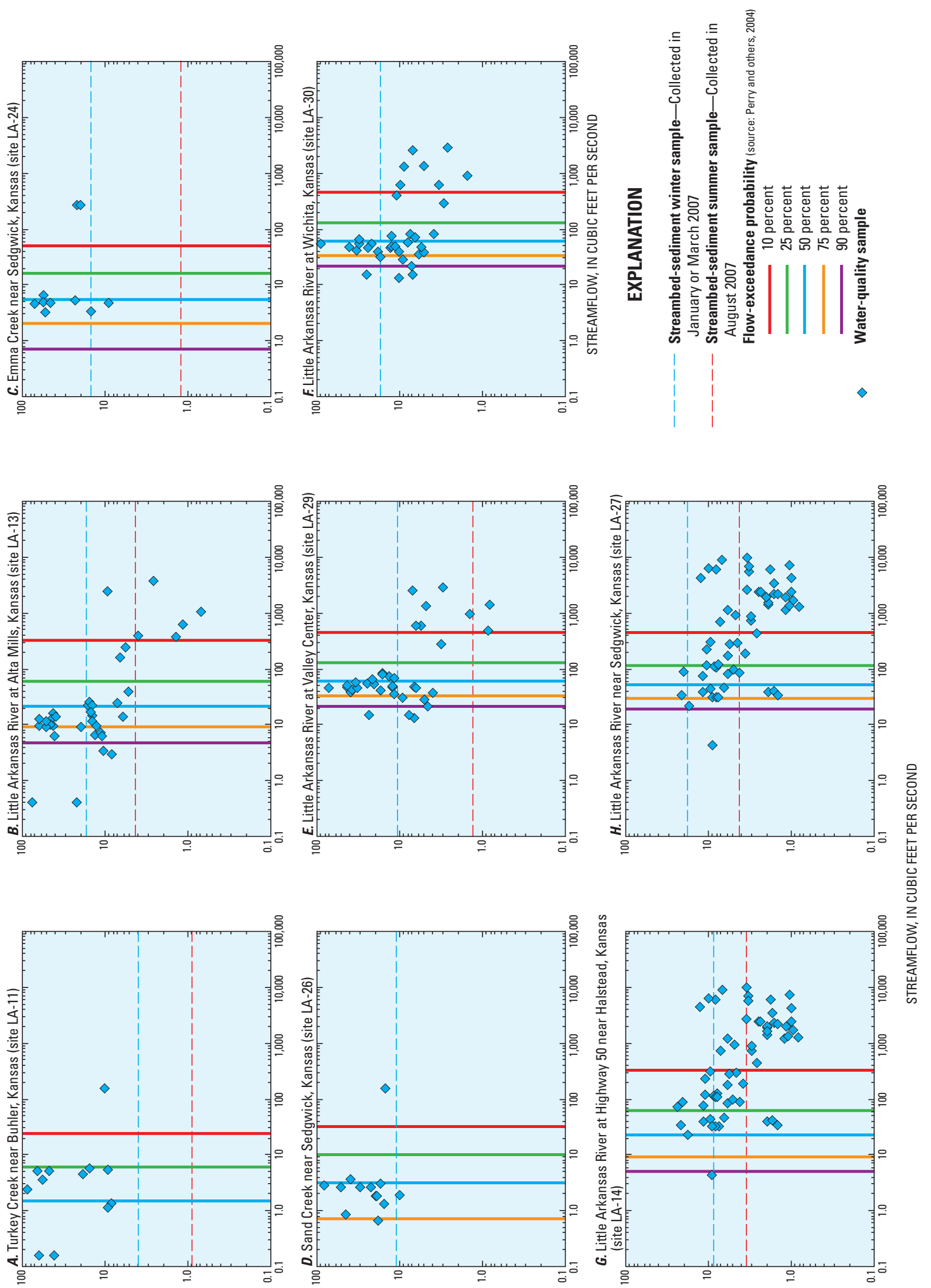

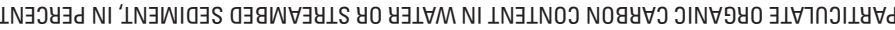

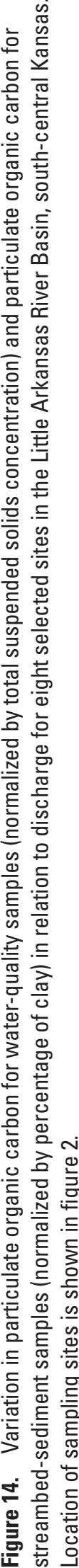


A couple of possibilities may account, in part, for the tendency of particulate N, P, and OC content in the water and streambed-sediment samples to decrease as streamflow increases. One possibility is that the decreased contents associated with the higher flows may be a result of a change in sediment source. During high flows the contribution of sediment from channel banks may increase (Knighton, 1998). Channel banks often have smaller concentrations of $\mathrm{N}, \mathrm{P}$, and $\mathrm{OC}$ as compared to surface soils (Walling and Kane, 1984; Walling and Woodward, 1995; Juracek and Ziegler, 2007). A second possibility is that the decreased contents may be indicative of a change in the particle-size composition of the less than $63-\mu \mathrm{m}$ fraction being transported by the higher flows. For example, $\mathrm{P}$ concentrations typically are inversely related to particle size (Pierzynski and others, 2005). Thus, the decrease in particulate $\mathrm{P}$ content associated with the higher flows may be indicative of an increase in particle size (that is, an increase in silt content) (Sharpley and Smith, 1993).

The results described above indicated that it may be possible to use streambed sediment as an indicator of water quality for N, P, and OC. Such an application needs to take into account flow conditions (that is, preceding streambedsediment sampling and during water-quality sampling) as there appears to be a generally consistent relation between flow conditions and particulate $\mathrm{N}, \mathrm{P}$, and $\mathrm{OC}$ content in the water and streambed-sediment samples. However, the use of particulate $\mathrm{N}$ to estimate water quality may not be appropriate because most of the $\mathrm{N}$ in streamflow draining agricultural basins is transported in the dissolved phase (Vanni and others, 2001).

\section{Summary and Conclusions}

The spatial and temporal variability in streambed-sediment quality and its relation to historical water quality was assessed to provide guidance for the development of total maximum daily loads and the implementation of best-management practices in the Little Arkansas River Basin, southcentral Kansas. Streambed-sediment samples were collected at 26 sites in 2007, sieved to isolate the less than 63-micron fraction (that is, the silt and clay), and analyzed for selected nutrients (total nitrogen and total phosphorus), organic and total carbon, 25 trace elements, and the radionuclides beryllium-7, cesium-137, lead-210, and radium-226. The sedimentchemical data were compared to historical water-quality data, available from KDHE and USGS at eight sites, to investigate the possibility of using sediment quality to estimate surfacewater quality. At eight sites, streambed-sediment samples also were collected and analyzed for bacteria. The major results of this study are listed below:

1. Particulate nitrogen, phosphorus, and organic carbon concentrations in the streambed sediment varied substantially both spatially and temporally, and positive correlations among the three constituents were statistically significant.
2. Along the main-stem Little Arkansas River, streambedsediment concentrations of particulate nitrogen and phosphorus generally were larger at and downstream from Alta Mills, Kansas.

3. The largest particulate nitrogen concentrations, possibly related to livestock and poultry production, were measured for two streambed-sediment samples collected in the Emma Creek subbasin.

4. The largest particulate phosphorus concentrations in the basin were measured for streambed-sediment samples collected along the main-stem Little Arkansas River downstream from Alta Mills, Kansas.

5. Generally, particulate nitrogen, phosphorus, and organic carbon content in the water and streambed-sediment samples decreased as streamflow increased at a site.

6. The inverse relation of particulate nitrogen, phosphorus, and organic carbon content with streamflow may be indicative of an increased contribution of sediment from channel-bank sources during high flows and (or) an increase in the particle size transported.

7. If flow conditions prior to sampling are taken into account, it may be possible to use streambed sediment as an indicator of water quality for nitrogen, phosphorus, and organic carbon.

8. Trace element concentrations in the streambed sediment varied from site to site and typically were less than threshold-effects guidelines for possible adverse biological effects.

9. The largest copper, lead, silver, and zinc concentrations, likely related to urban sources of contamination, were measured for a streambed-sediment sample collected from Sand Creek downstream from Newton, Kansas.

10. Radionuclide activities in the streambed sediment varied throughout the basin and may be indicative of subbasin differences in sediment sources.

11. Bacteria densities in the streambed sediment were variable.

\section{Acknowledgment}

This study was made possible in part by support from the Kansas State Water Plan Fund and the Kansas Department of Health and Environment. 


\section{References Cited}

Allan, J.D., 1995, Stream ecology-Structure and function of running waters: New York, Chapman \& Hall, 388 p.

American Public Health Association, 1998, Standard methods for the examination of water and wastewater (20th ed.): Washington, D.C., American Public Health Association, American Water Works Association, and Water Pollution Control Federation, 1,220 p.

Arbogast, B.F., 1996, Analytical methods manual for the Mineral Resource Surveys Program: U.S. Geological Survey Open-File Report 96-525, 248 p.

Baudo, Renato, Giesy, J.P., and Muntau, Herbert, eds., 1990, Sediments - Chemistry and toxicity of in-place pollutants: Ann Arbor, Michigan, Lewis Publishers, 405 p.

Briggs, P.H., and Meier, A.L., 1999, The determination of forty two elements in geological materials by inductively coupled plasma-mass spectrometry: U.S. Geological Survey Open-File Report 99-166, 15 p.

Britton, L.J., and Greeson, P.E., eds., 1989, Methods for collection and analysis of aquatic biological and microbiological samples: U.S. Geological Survey Techniques of WaterResources Investigations, book 5, chap. A4, 363 p.

Brower, Jennifer, and Cecchine, Gary, 2002, Bioavailability in sediments, chap. 3, in Whittemore, R.C. and others, Handbook on sediment quality: Alexandria, Virginia, Water Environment Federation, p. 99-137.

Eaton, A.D., Clesceri, L.S., Rice, E.W., Greenberg, A.E., and Franson, M.H., eds., 2005, Standard methods for the examination of water and wastewater (21st ed.): Washington, D.C., American Public Health Association, 1,368 p.

Feltz, H.R., 1980, Significance of bottom material data in evaluating water quality, chap. 11, in Baker, R.A., ed., Contaminants and sediments, vol. 1: Ann Arbor, Michigan, Ann Arbor Science Publishers, Inc., p. 271-287.

Fenneman, N.M., 1946, Physical divisions of the United States: U.S. Geological Survey special map, scale 1:7,000,000, 1 sheet.

Fishman, M.J., ed., 1993, Methods of analysis by the U.S. Geological Survey National Water Quality Laboratory-Determination of inorganic and organic constituents in water and fluvial sediments: U.S. Geological Survey Open-File Report 93-125, 217 p.

Fishman, M.J., and Friedman, L.C., eds., 1989, Methods for determination of inorganic substances in water and fluvial sediments: U.S. Geological Survey Techniques of WaterResources Investigations, book 5, chap. A1, 545 p.
Forstner, Ulrich, and Wittmann, G.T.W., 1981, Metal pollution in the aquatic environment: New York, Springer-Verlag, $486 \mathrm{p}$.

Fuller, C.C., van Geen, A., Baskaran, M., and Anima, R., 1999, Sediment chronology in San Francisco Bay, California, defined by ${ }^{210} \mathrm{~Pb},{ }^{234} \mathrm{Th},{ }^{137} \mathrm{Cs}$, and ${ }^{239,240} \mathrm{Pu}$ : Marine Chemistry, v. 64, p. 7-27.

Gray, J.R., Glysson, G.D., Turcios, L.M., and Schwarz, G.E., 2000, Comparability of suspended-sediment concentration and total suspended solids data: U.S. Geological Survey Water-Resources Investigations Report 00-4191, 14 p.

Guy, H.P., 1969, Laboratory theory and methods for sediment analysis: U.S. Geological Survey Techniques of WaterResources Investigations, book 5, chap. C1, 58 p.

Haggard, B.E., Smith, D.R., and Brye, K.R., 2007, Variations in stream water and sediment phosphorus among select Ozark catchments: Journal of Environmental Quality, v. 36, p. $1,725-1,734$.

Helsel, D.R., and Hirsch, R.M., 1992, Statistical methods in water resources: Amsterdam, Elsevier Science Publishers, $529 \mathrm{p}$.

High Plains Regional Climate Center, 2007, Historical data summaries: Information available on the Web, accessed April 13, 2007, at http://www.hprcc.unl.edu

Holtan, H., Kamp-Nielsen, L., and Stuanes, A.O., 1988, Phosphorus in soil, water and sediment-An overview: Hydrobiologia, v. 170, p. 19-34.

Horowitz, A.J., 1991, A primer on sediment-trace element chemistry (2nd ed.): Chelsea, Michigan, Lewis Publishers, $136 \mathrm{p}$.

Horowitz, A.J., Elrick, K.A., and Smith, J.J., 2001, Estimating suspended sediment and trace element fluxes in large river basins-Methodological considerations as applied to the NASQAN program: Hydrological Processes, v. 15, p. $1,107-1,132$.

Horowitz, A.J., and Stephens, V.C., 2008, The effects of land use on fluvial sediment chemistry for the conterminous U.S.-Results from the first cycle of the NAWQA program: Trace and major elements, phosphorus, carbon, and sulfur: Science of the Total Environment, v. 400, p. 290-314.

Jobbagy, E.G., and Jackson, R.B., 2000, The vertical distribution of soil organic carbon and its relation to climate and vegetation: Ecological Applications, v. 10, p. 423-436.

Juracek, K.E., 2004a, Sedimentation and occurrence and trends of selected chemical constituents in bottom sediment of 10 small reservoirs, eastern Kansas: U.S. Geological Survey Scientific Investigations Report 2004-5228, 80 p. 
Juracek, K.E., 2004b, Flood-related, organic-carbon anomalies as possible temporal markers in reservoir bottom sediments: Lake and Reservoir Management, v. 20, p. 309-321.

Juracek, K.E., and Ziegler, A.C., 2007, Estimation of sediment sources using selected chemical tracers in the Perry Lake and Lake Wabaunsee Basins, northeast Kansas: U.S. Geological Survey Scientific Investigations Report 2007-5020, $53 \mathrm{p}$.

Kansas Applied Remote Sensing Program, 1993, Kansas land cover data base, scale 1:100,000: Information available on the Web, accessed October 20, 2006, at http://www. KansasGIS.org

Kansas Department of Health and Environment, 2007, Kansas water-quality impaired water bodies (303(d) list): Information available on the Web, available from $h t t p: / / w w w$. kdheks.gov/tmdl/

Klotz, R.L., 1991, Temporal relation between soluble reactive phosphorus and factors in stream water and sediments in Hoxie Gorge Creek, New York: Canadian Journal of Fisheries and Aquatic Sciences, v. 48, p. 84-90.

Knighton, D., 1998, Fluvial forms and processes-A new perspective: New York, John Wiley and Sons, 383 p.

Lee, C.J., Mau, D.P., and Rasmussen, T.J., 2005, Effects of nonpoint and selected point contaminant sources on stream-water quality and relation to land use in Johnson County, northeastern Kansas, October 2002 through June 2004: U.S. Geological Survey Scientific Investigations Report 2005-5144, 104 p.

MacDonald, D.D., Ingersoll, C.G., and Berger, T.A., 2000, Development and evaluation of consensus-based sediment quality guidelines for freshwater ecosystems: Archives of Environmental Contamination and Toxicology, v. 39, p. 20-31.

Miller, J.R., and Orbock Miller, S.M., 2007, Contaminated rivers-A geomorphological-geochemical approach to site assessment and remediation: Dordrecht, The Netherlands, Springer, $418 \mathrm{p}$.

Myers, D.N., Stoeckel, D.M., Bushon, R.N., Francy, D.S., and Brady, A.M.G., 2007, Fecal indicator bacteria: U.S. Geological Survey Techniques of Water-Resources Investigations, book 9, chap. A7, section 7.1 (version 2.0), available from http://pubs.water.usgs.gov/twri9A

National Hydrography Dataset Plus, 2007, 30-meter digital elevation model data, accessed at http://www.horizonsystems.com/nhdplus/index.php
Neal, C., Robson, A.J., Harrow, M., Hill, L., Wickham, H., Bhardwaj, C.L., Tindall, C.I., Ryland, G.P., Leach, D.V., Johnson, R.C., Bronsdon, R.K., and Cranston, M., 1997, Major, minor, trace element and suspended sediment variations in the River Tweed-Results from the LOIS core monitoring programme: The Science of the Total Environment, v. 194/195, p. 193-205.

Olsen, C.R., Larsen, I.L., Lowry, P.D., Cutshall, N.H., and Nichols, M.M., 1986, Geochemistry and deposition of ${ }^{7} \mathrm{Be}$ in river-estuarine and coastal waters: Journal of Geophysical Research, v. 91, p. 896-908.

Pais, Istvan, and Jones, J.B., Jr., 1997, The handbook of trace elements: Boca Raton, Florida, St. Lucie Press, 223 p.

Patton, C.J., and Kryskalla, J.R., 2003, Methods of analysis by the U.S. Geological Survey National Water Quality Laboratory-Evaluation of alkaline persulfate digestion as an alternative to Kjeldahl digestion for determination of total and dissolved nitrogen and phosphorus in water: U.S. Geological Survey Water-Resources Investigations Report 03-4174, 33 p.

Patton, C.J., and Truitt, E.P., 1992, Methods of analysis by the U.S. Geological Survey National Water Quality Laboratory-Determination of total phosphorus by a Kjeldahl digestion method and an automated colorimetric finish that includes dialysis: U.S. Geological Survey Open-File Report 92-146, 39 p.

Perry, C.A., Wolock, D.M., and Artman, J.A., 2004, Estimates of flow duration, mean flow, and peak-discharge frequency values for Kansas stream locations: U.S. Geological Survey Scientific Investigations Report 2004-5033, 219 p.

Pierzynski, G.M., Sims, J.T., and Vance, G.F., 2005, Soils and environmental quality (3rd ed.): New York, Taylor \& Francis, 569 p.

Preston, S.D., Bierman, V.J., Jr., and Silliman, S.E., 1989, An evaluation of methods for the estimation of tributary mass loads: Water Resources Research, v. 25, p. 1,379-1,389.

Robbins, J.A., and Edgington, D.N., 1975, Determination of recent sedimentation rates in Lake Michigan using $\mathrm{Pb}-210$ and Cs-137: Geochimica et Cosmochimica Acta, v. 39, p. $285-304$.

Rosensteel, B.A., and Strom, P.F., 1991, River phosphorus dynamics and reservoir eutrophication potential: Water Resources Bulletin, v. 27, p. 957-965.

Schoewe, W.H., 1949, The geography of Kansas: Transactions Kansas Academy of Science, v. 52, p. 261-333.

Sharpley, A.N., and Smith, S.J., 1993, Prediction of bioavailable phosphorus loss in agricultural runoff: Journal of Environmental Quality, v. 22, p. 32-37. 
Smol, J.P., 2002, Pollution of lakes and rivers-A paleoenvironmental perspective: New York, Oxford University Press, $280 \mathrm{p}$.

U.S. Environmental Protection Agency, 1982, Methods for organic chemical analysis of municipal and industrial wastewater: Cincinnati, Ohio, U.S. Environmental Protection Agency, EPA 600/4-82-057, 159 p.

U.S. Environmental Protection Agency, 1983, Methods for chemical analysis of water and wastes: Cincinnati, Ohio, U.S. Environmental Protection Agency, EPA 600/4-79-020, $491 \mathrm{p}$.

U.S. Environmental Protection Agency, 1991, Guidance of water quality-based decisions - The TMDL process: Washington, D.C., Office of Water, EPA440/4-91-001, 59 p.

U.S. Environmental Protection Agency, 1997, The incidence and severity of sediment contamination in surface waters of the United States, volume 1-National sediment quality survey: U.S. Environmental Protection Agency Report 823-R-97-006, September 1997, various pagination.

U.S. Geological Survey, 2006, Collection of water samples (ver. 2.0): U.S. Geological Survey Techniques of WaterResources Investigations, book 9, chap. A4, accessed January 28,2008 , at http://pubs.water.usgs.gov/twri9A4/
Vaithiyanathan, P., and Correll, D.L., 1992, The Rhode River watershed-Phosphorus distribution and export in forest and agricultural soils: Journal of Environmental Quality, v. 21, p. $280-288$.

Vanni, M.J., Renwick, W.H., Headworth, J.L., Auch, J.D., and Schaus, M.H., 2001, Dissolved and particulate nutrient flux from three adjacent agricultural watersheds - A five-year study: Biogeochemistry, v. 54, p. 85-114.

Walling, D.E., and Kane, P., 1984, Suspended sediment properties and their geomorphological significance, chap. 19, in Burt, T.P., and Walling, D.E., eds., Catchment experiments in fluvial geomorphology: Norwich, England, Geo Books, p. 311-334.

Walling, D.E., and Woodward, J.C., 1995, Tracing sources of suspended sediment in river basins - A case study of the River Culm, Devon, UK: Marine and Freshwater Research, v. 46, p. $327-336$.

Wentworth, C.K., 1922, A scale of grade and class terms for clastic sediments: Journal of Geology, v. 30, p. 377-392.

Zoumis, Theofanis, Schmidt, Astrid, Grigorova, Lidia, and Calmano, Wolfgang, 2001, Contaminants in sedimentsRemobilisation and demobilisation: The Science of the Total Environment, v. 266, p. 195-202. 

Supplemental Information 
Table A1. Dates sampled and latitude and longitude coordinates for streambed-sediment sampling sites in the Little Arkansas River Basin, south-central Kansas.

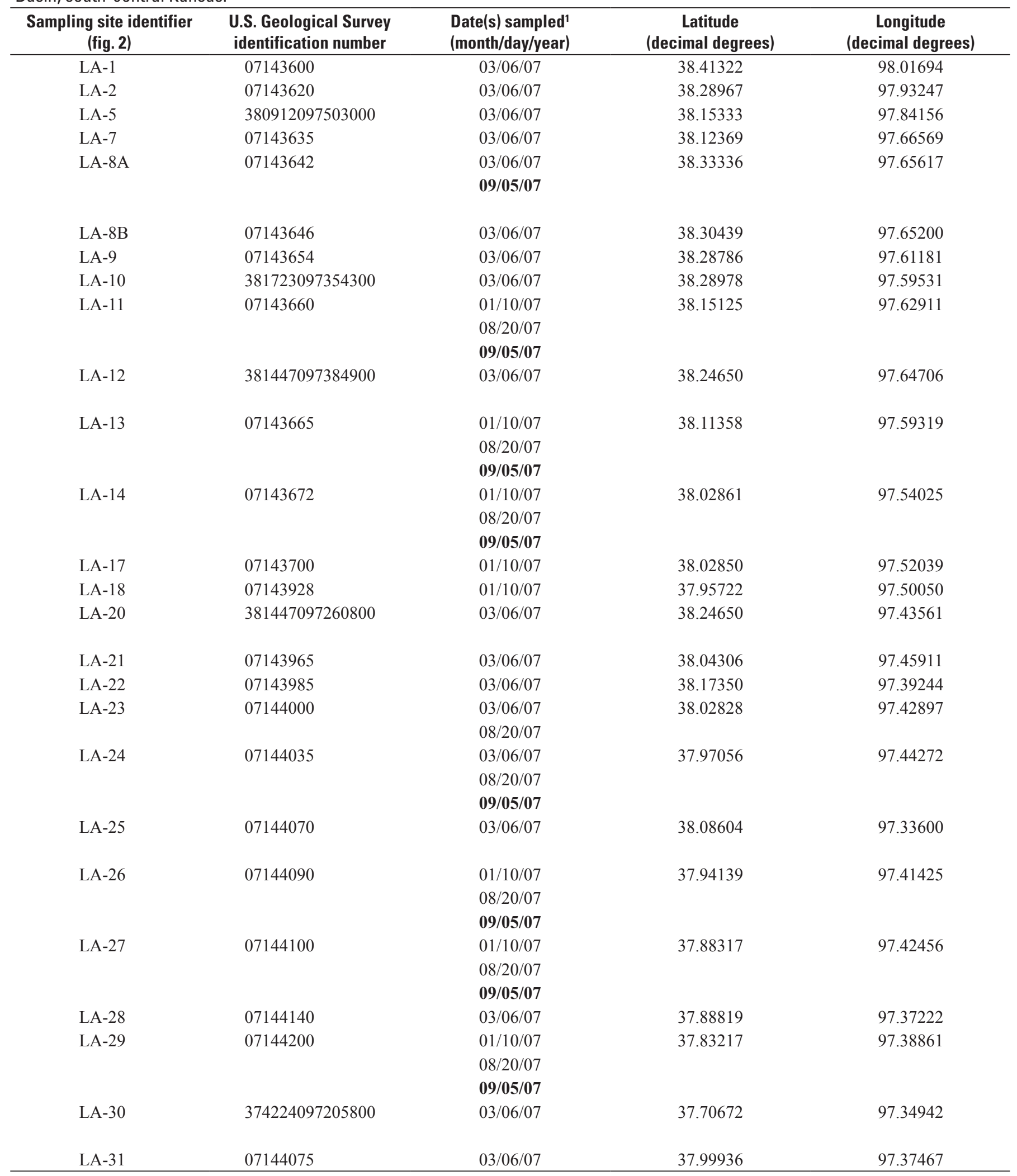

\footnotetext{
${ }^{1}$ Sampling dates for chemical analyses shown in regular font. Sampling dates for bacteria analyses shown in bold font.
} 
Table A2. Percentage of silt and clay and constituent concentrations or activities for streambed-sediment samples collected from the Little Arkansas River Basin, south-central Kansas, January and March 2007.

[Location of sampling sites shown in figure 2. Values in parentheses are clay normalized. Values in brackets are organic-carbon normalized. Shading indicates concentration greater than threshold-effects guideline listed in table 3. mg/kg, milligrams per kilogram; \%, percent dry weight; dpm/g, disintegrations per minute per gram; pCi/g, picocuries per gram; <, less than; --, not determined]

\begin{tabular}{|c|c|c|c|c|}
\hline \multirow{2}{*}{$\begin{array}{c}\text { Constituent and unit of } \\
\text { measurement }\end{array}$} & \multicolumn{4}{|c|}{ Constituent concentration or activity } \\
\hline & Site LA-1 & Site LA-2 & Site LA-5 & Site LA-7 \\
\hline Percentage of silt and clay ${ }^{1}$ & 47 & 55 & 17 & 46 \\
\hline \multicolumn{5}{|c|}{ Nutrients } \\
\hline Particulate nitrogen, $\mathrm{mg} / \mathrm{kg}$ & $\begin{array}{r}1,400 \\
(7,400) \\
{[108,000]}\end{array}$ & $\begin{array}{r}1,100 \\
(9,200) \\
{[100,000]}\end{array}$ & $\begin{array}{c}1,800 \\
(15,000) \\
{[90,000]}\end{array}$ & $\begin{array}{r}700 \\
(2,300) \\
{[100,000]}\end{array}$ \\
\hline Particulate phosphorus, $\mathrm{mg} / \mathrm{kg}$ & $\begin{array}{r}610 \\
(3,200) \\
{[46,900]} \\
\end{array}$ & $\begin{array}{r}610 \\
(5,100) \\
{[55,500]} \\
\end{array}$ & $\begin{array}{r}840 \\
(7,000) \\
{[42,000]} \\
\end{array}$ & $\begin{array}{r}630 \\
(2,100) \\
{[90,000]} \\
\end{array}$ \\
\hline \multicolumn{5}{|c|}{ Carbon } \\
\hline Particulate organic carbon, $\%$ & 1.3 & 1.1 & 2.0 & 0.7 \\
\hline Carbon (total), $\%$ & 1.5 & 1.3 & 2.3 & .8 \\
\hline Arsenic, mg/kg & 4.9 & 5.9 & 7.3 & 7.3 \\
\hline Barium, mg/kg & 660 & 660 & 740 & 740 \\
\hline Beryllium, mg/kg & 1.7 & 1.8 & 2.2 & 1.8 \\
\hline Cadmium, mg/kg & .2 & .2 & .4 & .3 \\
\hline Chromium, mg/kg & 42 & 47 & 58 & 48 \\
\hline Cobalt, mg/kg & 8 & 11 & 14 & 13 \\
\hline Copper, mg/kg & 14 & 15 & 22 & 17 \\
\hline Iron, $\%$ & 2.1 & 2.2 & 3.1 & 2.4 \\
\hline Silver, mg/kg & $<.5$ & $<.5$ & $<.5$ & $<.5$ \\
\hline Strontium, mg/kg & 150 & 160 & 180 & 150 \\
\hline Sulfur, $\%$ & .03 & .03 & .05 & .02 \\
\hline Thallium, mg/kg & $<50$ & $<50$ & $<50$ & $<50$ \\
\hline Tin, mg/kg & 1 & 2 & 2 & 2 \\
\hline Titanium, $\%$ & .39 & .40 & .41 & .40 \\
\hline Uranium, mg/kg & $<50$ & $<50$ & $<50$ & $<50$ \\
\hline Vanadium, mg/kg & 66 & 70 & 89 & 79 \\
\hline Zinc, mg/kg & 61 & 62 & 93 & 68 \\
\hline \multicolumn{5}{|c|}{ Radionuclides } \\
\hline Beryllium-7, dpm/g & 1.1 & $<.4$ & 2.7 & 1.5 \\
\hline Cesium-137, pCi/g & .14 & .06 & .16 & .05 \\
\hline Lead-210, dpm/g & 4.95 & 3.20 & 4.44 & 3.70 \\
\hline Radium-226, dpm/g & 2.34 & 2.61 & 2.18 & 2.47 \\
\hline
\end{tabular}


Table A2. Percentage of silt and clay and constituent concentrations or activities for streambed-sediment samples collected from the Little Arkansas River Basin, south-central Kansas, January and March 2007._Continued

[Location of sampling sites shown in figure 2. Values in parentheses are clay normalized. Values in brackets are organic-carbon normalized. Shading indicates concentration greater than threshold-effects guideline listed in table $3 . \mathrm{mg} / \mathrm{kg}$, milligrams per kilogram; \%, percent dry weight; dpm/g, disintegrations per minute per gram; pCi/g, picocuries per gram; <, less than; --, not determined]

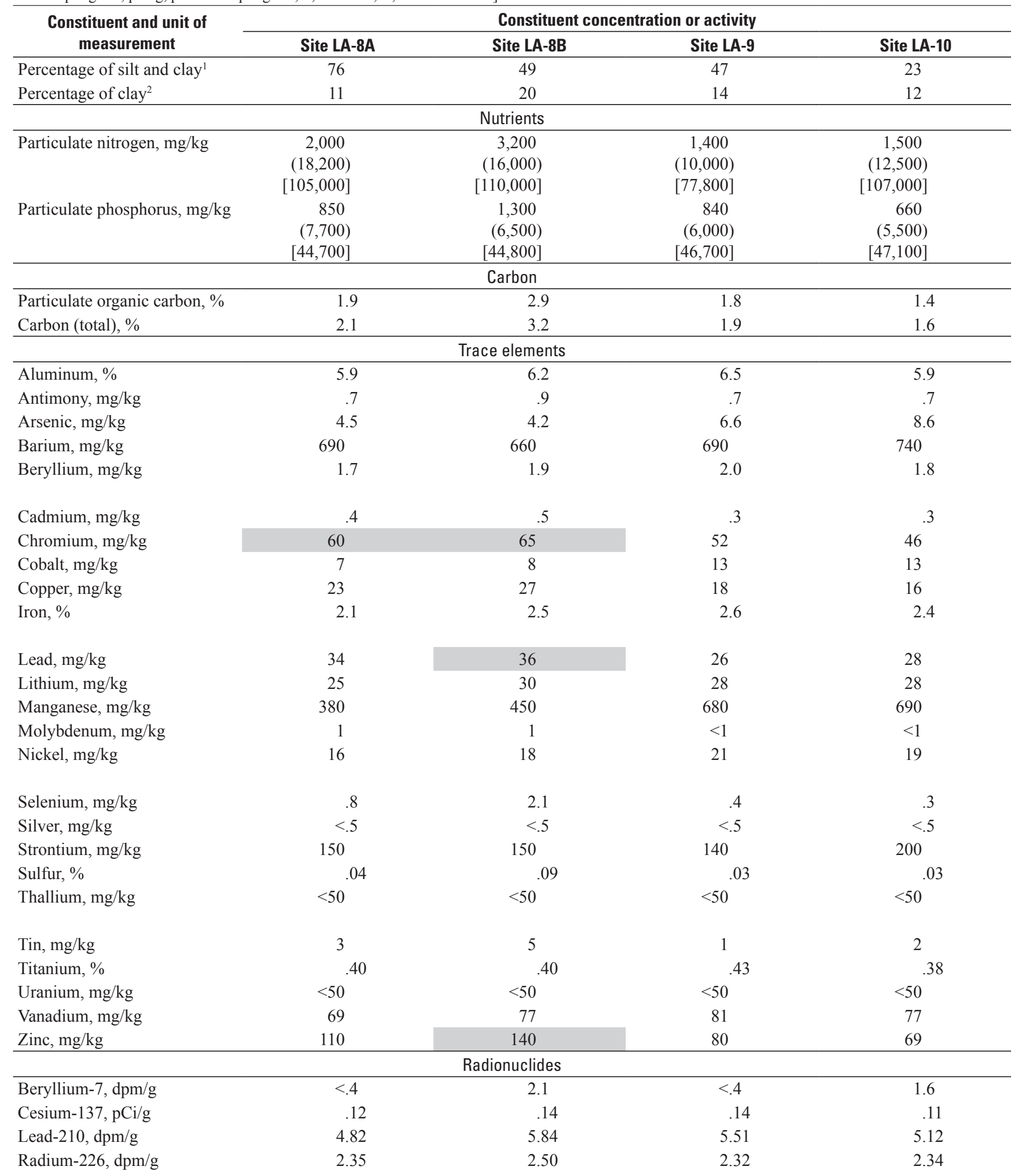


Table A2. Percentage of silt and clay and constituent concentrations or activities for streambed-sediment samples collected from the Little Arkansas River Basin, south-central Kansas, January and March 2007._-Continued

[Location of sampling sites shown in figure 2. Values in parentheses are clay normalized. Values in brackets are organic-carbon normalized. Shading indicates concentration greater than threshold-effects guideline listed in table $3 . \mathrm{mg} / \mathrm{kg}$, milligrams per kilogram; \%, percent dry weight; dpm/g, disintegrations per minute per gram; $\mathrm{pCi} / \mathrm{g}$, picocuries per gram; <, less than; --, not determined]

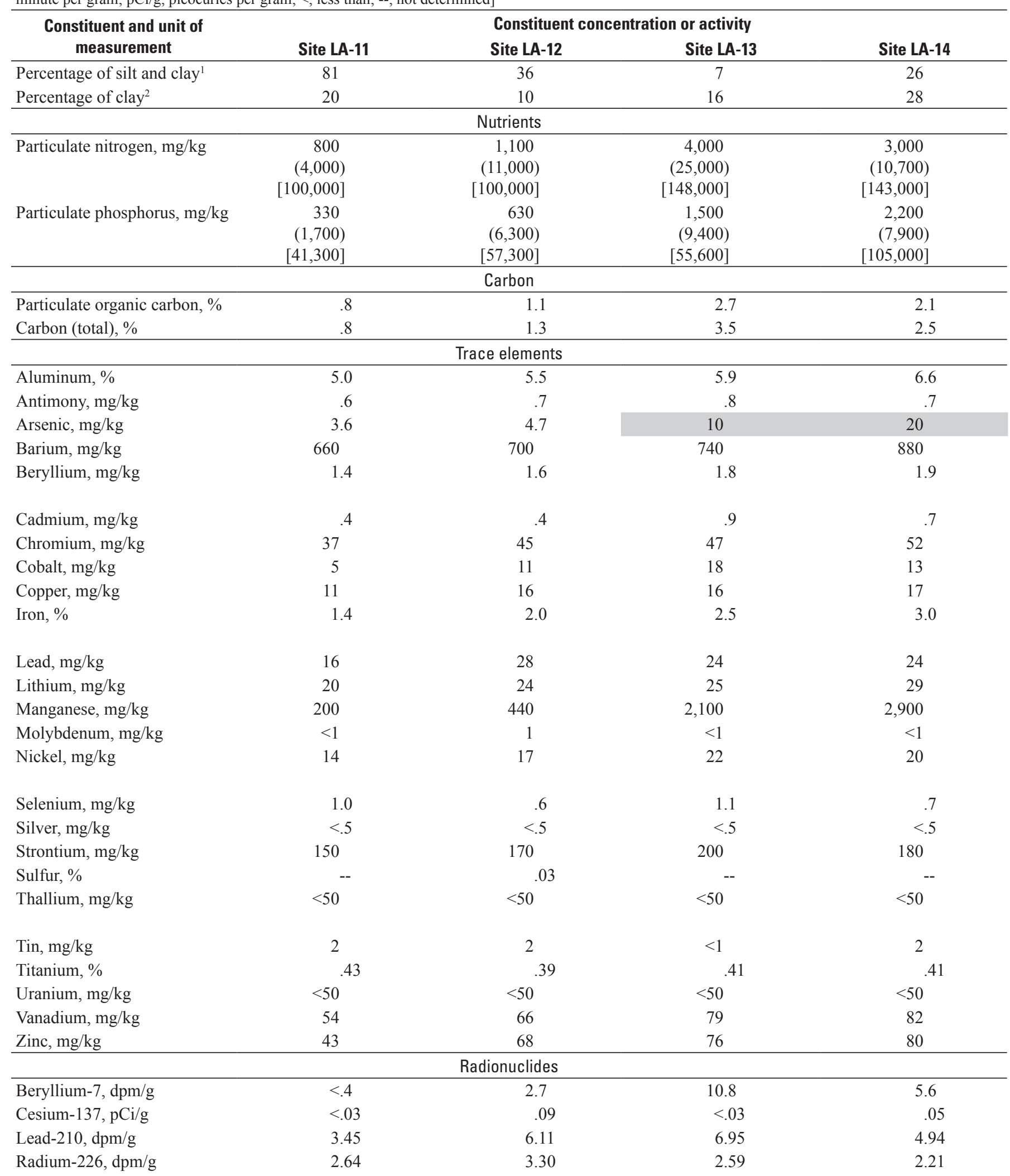


Table A2. Percentage of silt and clay and constituent concentrations or activities for streambed-sediment samples collected from the Little Arkansas River Basin, south-central Kansas, January and March 2007._Continued

[Location of sampling sites shown in figure 2. Values in parentheses are clay normalized. Values in brackets are organic-carbon normalized. Shading indicates concentration greater than threshold-effects guideline listed in table $3 . \mathrm{mg} / \mathrm{kg}$, milligrams per kilogram; \%, percent dry weight; dpm/g, disintegrations per minute per gram; $\mathrm{pCi} / \mathrm{g}$, picocuries per gram; <, less than; --, not determined]

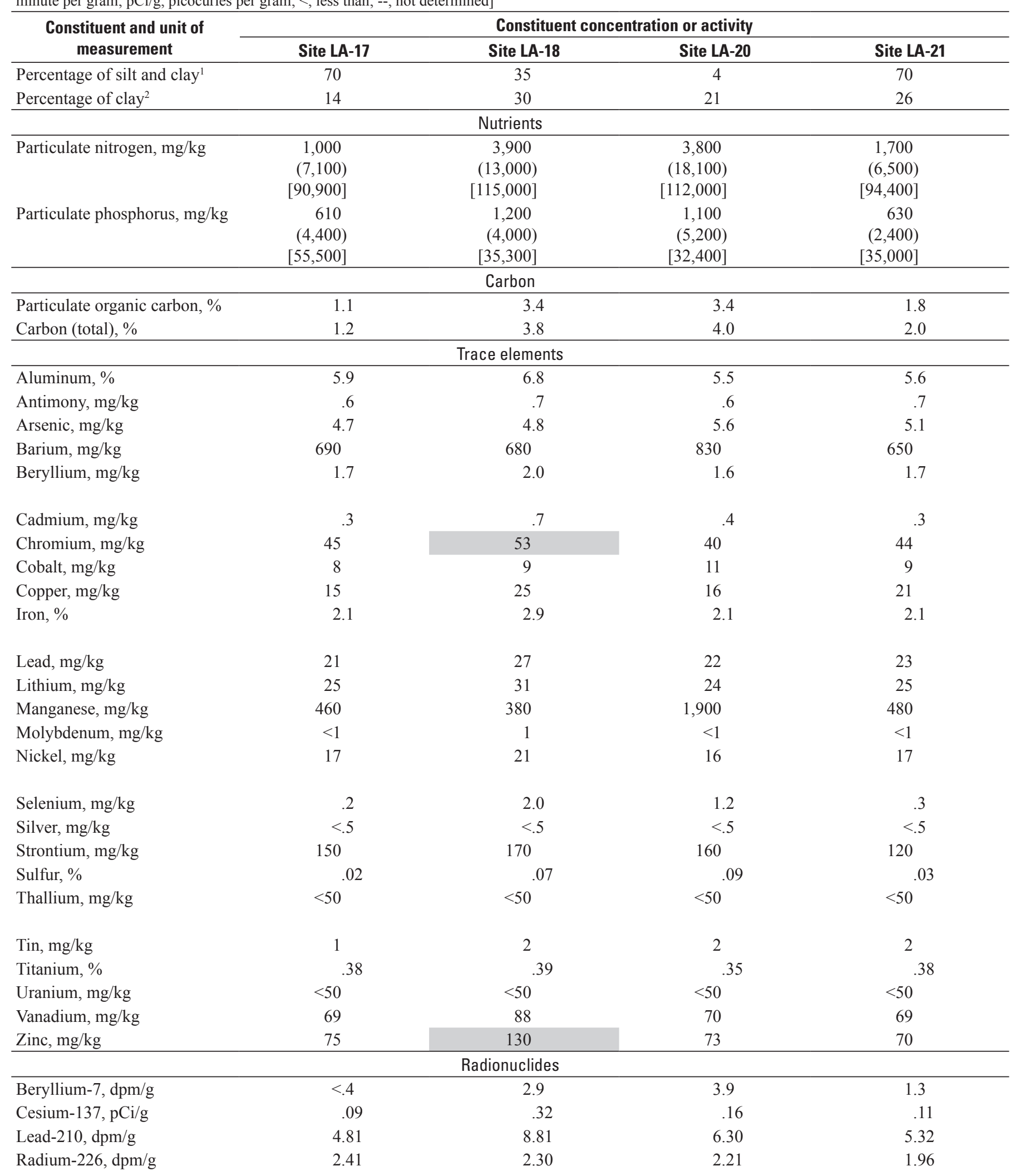


Table A2. Percentage of silt and clay and constituent concentrations or activities for streambed-sediment samples collected from the Little Arkansas River Basin, south-central Kansas, January and March 2007.-Continued

[Location of sampling sites shown in figure 2. Values in parentheses are clay normalized. Values in brackets are organic-carbon normalized. Shading indicates concentration greater than threshold-effects guideline listed in table $3 . \mathrm{mg} / \mathrm{kg}$, milligrams per kilogram; \%, percent dry weight; dpm/g, disintegrations per minute per gram; $\mathrm{pCi} / \mathrm{g}$, picocuries per gram; <, less than; --, not determined]

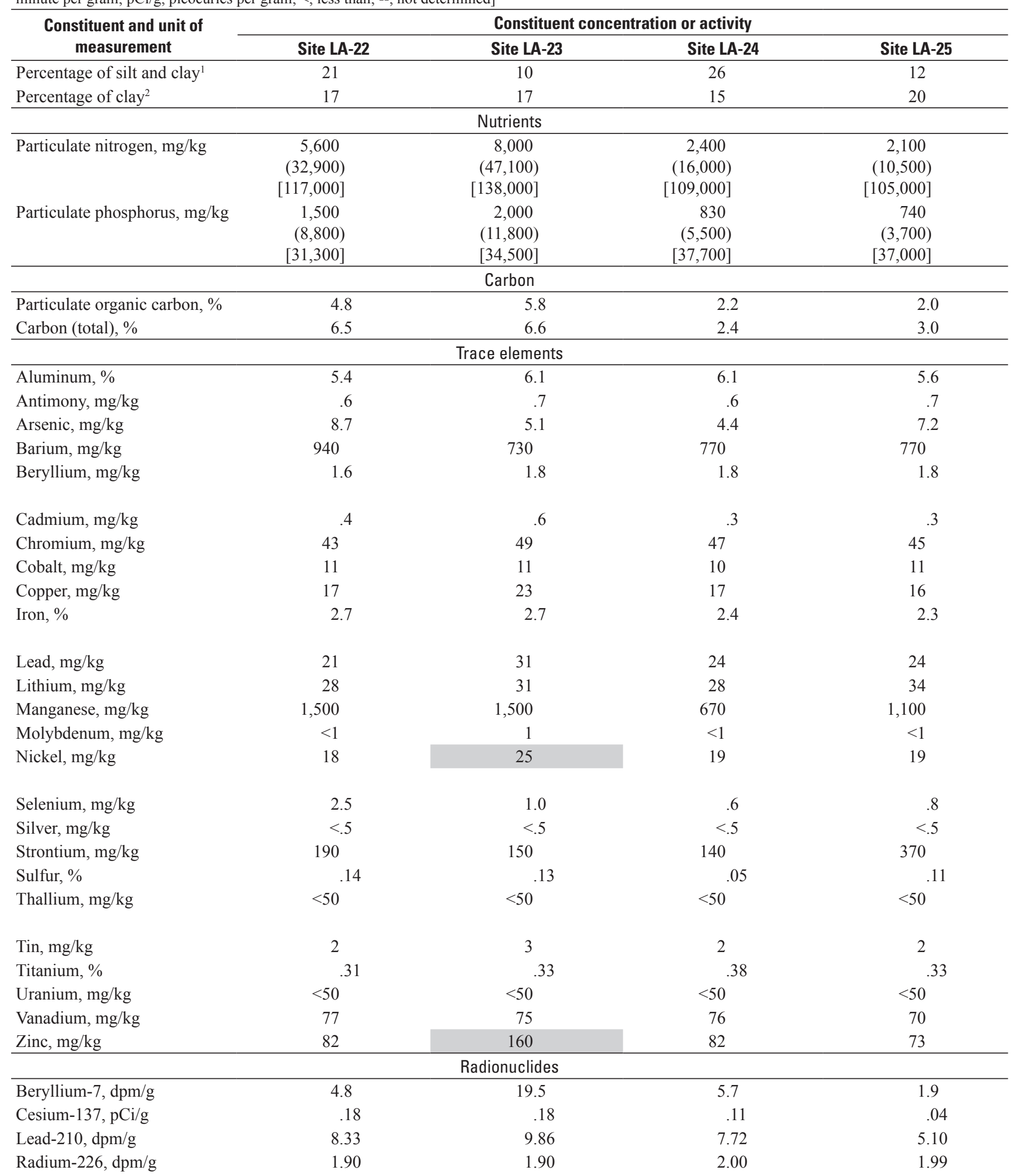


Table A2. Percentage of silt and clay and constituent concentrations or activities for streambed-sediment samples collected from the Little Arkansas River Basin, south-central Kansas, January and March 2007._Continued

[Location of sampling sites shown in figure 2. Values in parentheses are clay normalized. Values in brackets are organic-carbon normalized. Shading indicates concentration greater than threshold-effects guideline listed in table 3. mg/kg, milligrams per kilogram; \%, percent dry weight; dpm/g, disintegrations per minute per gram; $\mathrm{pCi} / \mathrm{g}$, picocuries per gram; $<$, less than; --, not determined]

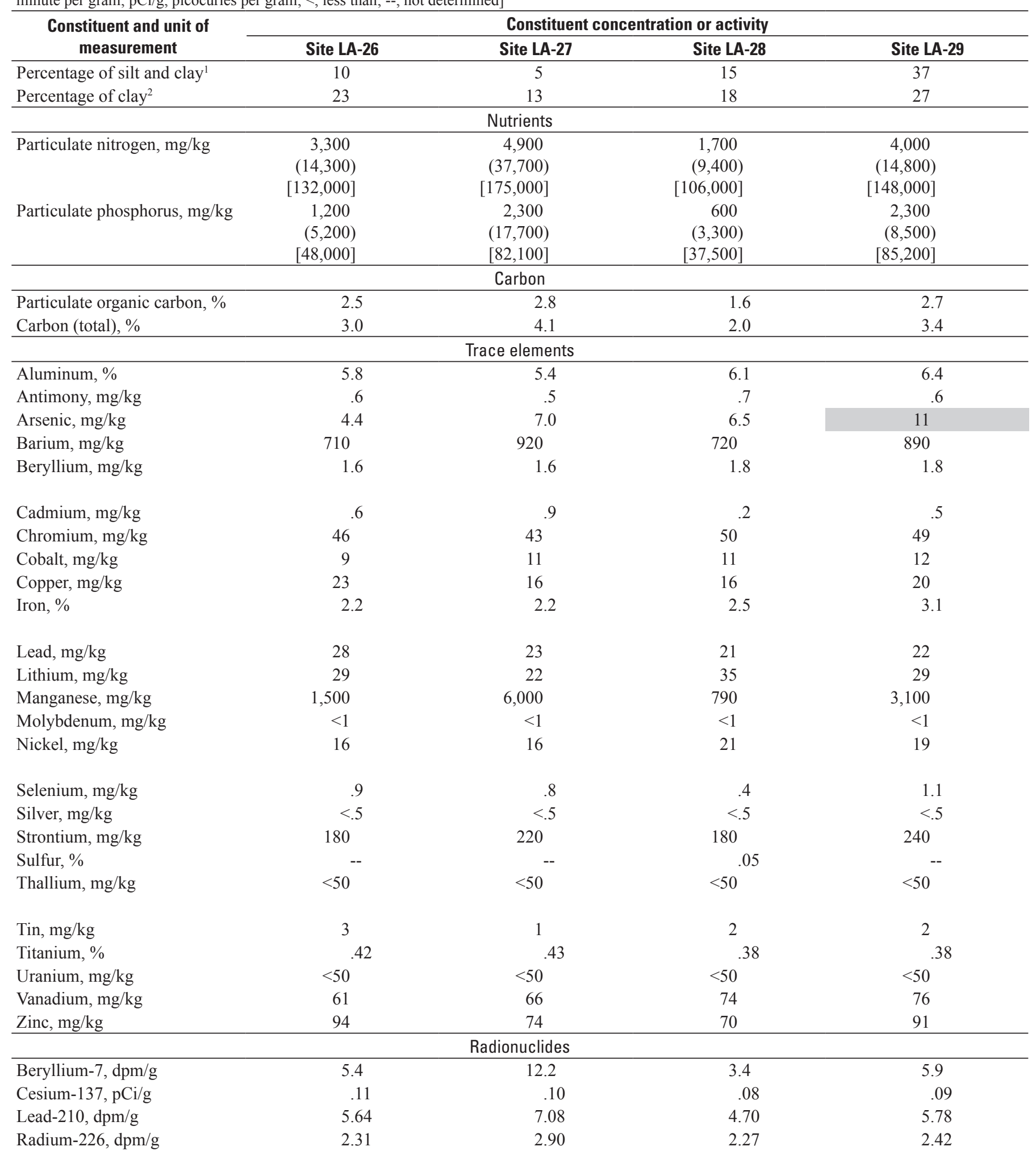


Table A2. Percentage of silt and clay and constituent concentrations or activities for streambed-sediment samples collected from the Little Arkansas River Basin, south-central Kansas, January and March 2007._Continued

[Location of sampling sites shown in figure 2. Values in parentheses are clay normalized. Values in brackets are organic-carbon normalized. Shading indicates concentration greater than threshold-effects guideline listed in table 3. $\mathrm{mg} / \mathrm{kg}$, milligrams per kilogram; \%, percent dry weight; dpm/g, disintegrations per minute per gram; pCi/g, picocuries per gram; <, less than; --, not determined]

Constituent and unit of measurement

Percentage of silt and clay ${ }^{1}$

Percentage of clay ${ }^{2}$

Particulate nitrogen, $\mathrm{mg} / \mathrm{kg}$

Particulate phosphorus, $\mathrm{mg} / \mathrm{kg}$

Constituent concentration or activity

Site LA-30 Site LA-31

26

30

23

Nutrients

$\begin{array}{cc}4,900 & 2,800 \\ (21,300) & (9,300) \\ {[117,000]} & {[100,000]} \\ 1,800 & 1,700 \\ (7,800) & (5,700) \\ {[42,900]} & {[60,700]}\end{array}$

Carbon

\begin{tabular}{lll}
\hline Particulate organic carbon, \% & 4.2 & 2.8
\end{tabular}

Carbon (total), \%

6.7

3.4

\begin{tabular}{|c|c|c|}
\hline \multicolumn{3}{|c|}{ Trace elements } \\
\hline Aluminum, $\%$ & 4.7 & 5.7 \\
\hline Antimony, mg/kg & 6 & .8 \\
\hline Arsenic, mg/kg & 6.0 & 4.4 \\
\hline Barium, mg/kg & 610 & 730 \\
\hline Beryllium, mg/kg & 1.4 & 1.7 \\
\hline Cadmium, mg/kg & .6 & .3 \\
\hline Chromium, mg/kg & 37 & 51 \\
\hline Cobalt, mg/kg & 6 & 9 \\
\hline Copper, mg/kg & 19 & 60 \\
\hline Iron, $\%$ & 2.0 & 2.5 \\
\hline Lead, mg/kg & 30 & 51 \\
\hline Lithium, mg/kg & 24 & 34 \\
\hline Manganese, $\mathrm{mg} / \mathrm{kg}$ & 940 & 1,200 \\
\hline Molybdenum, mg/kg & $<1$ & $<1$ \\
\hline Nickel, mg/kg & 15 & 21 \\
\hline Selenium, mg/kg & 1.2 & 1.2 \\
\hline Silver, mg/kg & $<.5$ & .9 \\
\hline Strontium, mg/kg & 400 & 210 \\
\hline Sulfur, $\%$ & .17 & .10 \\
\hline Thallium, mg/kg & $<50$ & $<50$ \\
\hline Tin, mg/kg & 3 & 4 \\
\hline Titanium, $\%$ & .28 & .35 \\
\hline Uranium, mg/kg & $<50$ & $<50$ \\
\hline Vanadium, mg/kg & 56 & 64 \\
\hline Zinc, $\mathrm{mg} / \mathrm{kg}$ & 120 & 180 \\
\hline & Radionuc & \\
\hline Beryllium-7, dpm/g & 10.3 & 5.1 \\
\hline Cesium-137, pCi/g & .14 & .13 \\
\hline Lead-210, dpm/g & 8.63 & 6.87 \\
\hline Radium-226, dpm/g & 1.93 & 2.11 \\
\hline
\end{tabular}

${ }^{1}$ Percentage of silt and clay in bulk sample.

${ }^{2}$ Percentage of clay in the less than $63-\mu \mathrm{m}$ fraction. Values rounded to nearest whole number. 
Table A3. Percentage of silt and clay and constituent concentrations or activities for streambed-sediment samples collected from the Little Arkansas River Basin, south-central Kansas, August 2007.

[Location of sampling sites shown in figure 2. Shading indicates concentration greater than threshold-effects guideline listed in table $3 . \mathrm{mg} / \mathrm{kg}$, milligrams per kilogram; \%, percent dry weight; dpm/g, disintegrations per minute per gram; $\mathrm{pCi} / \mathrm{g}$, picocuries per gram; <, less than]

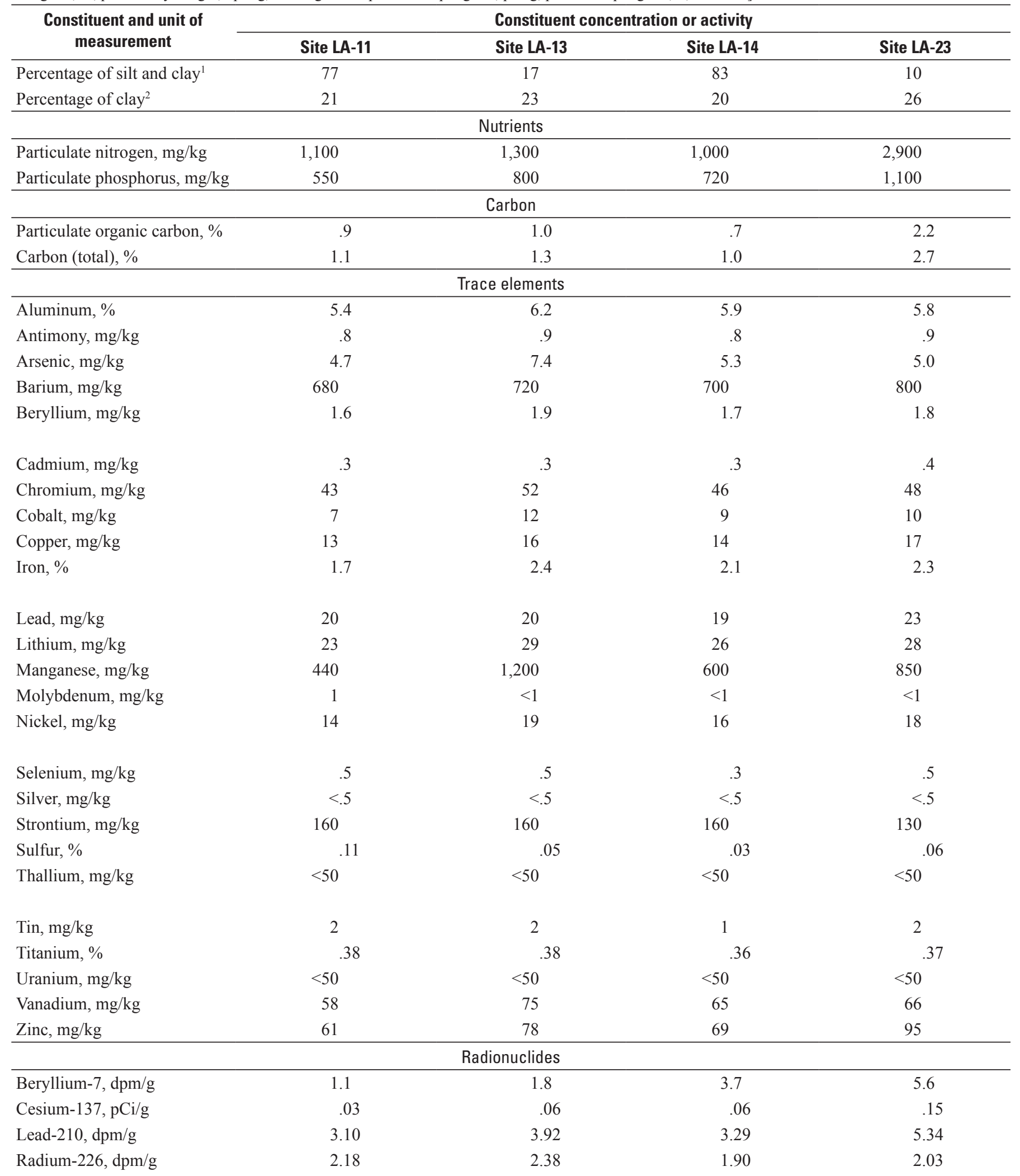


Table A3. Percentage of silt and clay and constituent concentrations or activities for streambed-sediment samples collected from the Little Arkansas River Basin, south-central Kansas, August 2007.-Continued

[Location of sampling sites shown in figure 2. Shading indicates concentration greater than threshold-effects guideline listed in table $3 . \mathrm{mg} / \mathrm{kg}$, milligrams per kilogram; \%, percent dry weight; dpm/g, disintegrations per minute per gram; $\mathrm{pCi} / \mathrm{g}$, picocuries per gram; $<$, less than]

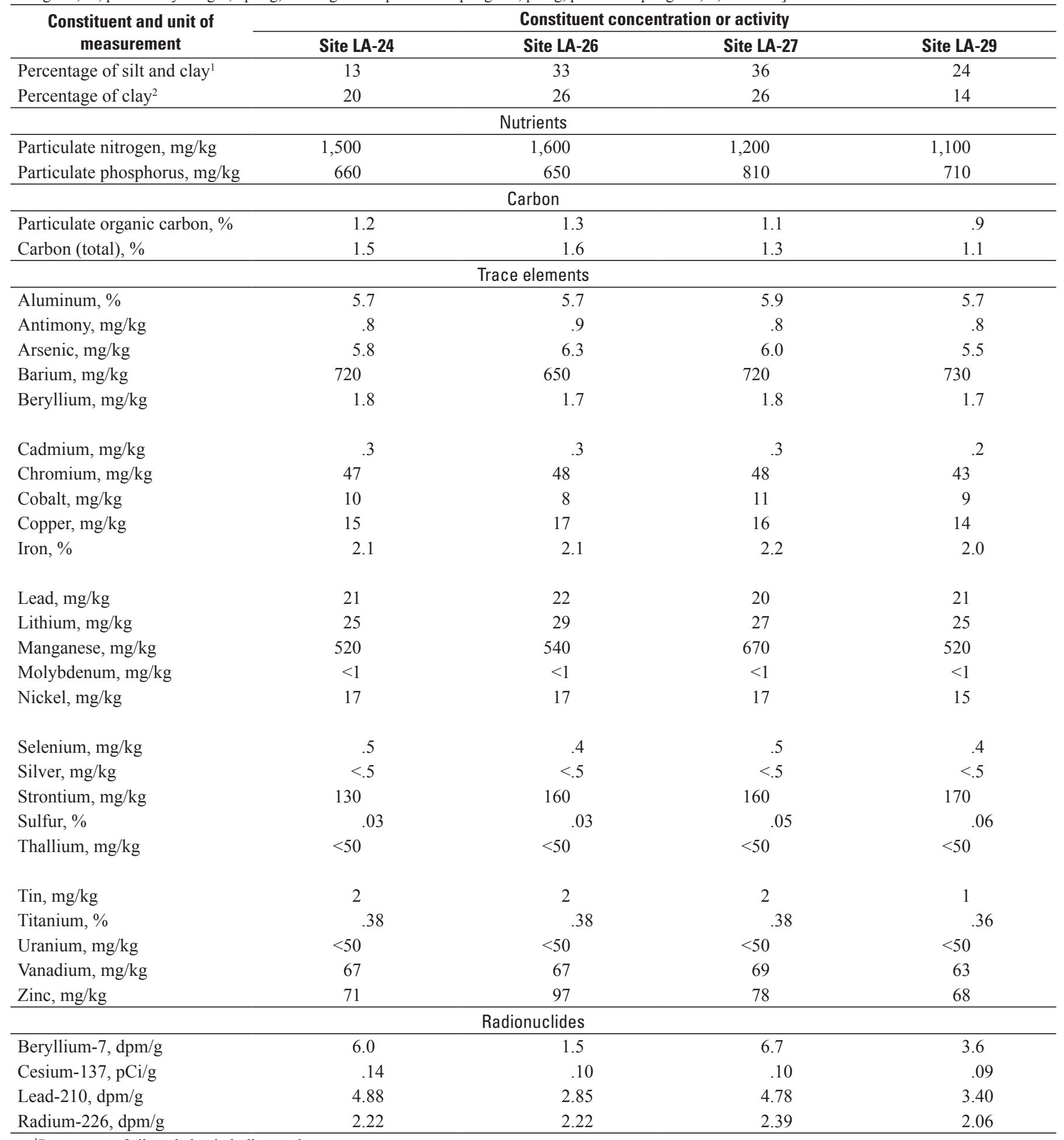

\footnotetext{
${ }^{1}$ Percentage of silt and clay in bulk sample.
}

${ }^{2}$ Percentage of clay in the less than $63-\mu \mathrm{m}$ fraction. Values rounded to nearest whole number. 
Publishing support provided by:

Rolla Publishing Service Center

For more information concerning this publication, contact:

Director, USGS Kansas Water Science Center

4821 Quail Crest Place

Lawrence, KS 66049

(785) 842-9909

Or visit the Kansas Water Science Center Web site at: http://ks.water.usgs.gov 

